\title{
How long do external capital constraints matter?
}

\section{A Study Based on Swiss Data for the Start-up Cohort 1996-97}

\section{Working Paper}

Author(s):

Stucki, Tobias

Publication date:

2009-11

Permanent link:

https://doi.org/10.3929/ethz-a-005996033

Rights / license:

In Copyright - Non-Commercial Use Permitted

Originally published in:

KOF Working Papers 241 


\section{KOF Working Papers}

How Long Do External Capital Constraints Matter?

Tobias Stucki 


\section{KOF}

ETH Zurich

KOF Swiss Economic Institute WEH D 4

Weinbergstrasse 35

8092 Zurich

Switzerland

Phone +41446324239

Fax +4144 6321218

www.kof.ethz.ch

kof@kof.ethz.ch 


\section{How Long Do External Capital Constraints Matter?}

A Study Based on Swiss Data for the Start-up Cohort 1996-97

Tobias Stucki

ETH Zurich, KOF Swiss Economic Institute

CH-8092 Zurich

Phone: $\quad+41446326307$

Fax: $\quad+41446321352$

E-mail: $\quad$ tobias.stucki@kof.ethz.ch

Keywords: start-ups; performance; financial constraints; firm age

JEL classification: M13; L25; G32

Acknowledgment: I thank Spyros Arvanitis, Thomas Bolli and Ulrich Kaiser for helpful comments and suggestions and David Marmet for his contributions to the compilation of the data. 


\begin{abstract}
Start-ups mostly have only limited internal financing. Post-entry performance should thus strongly depend on the availability of new external capital. In this study we analyze the impact of financial constraints on the performance of Swiss start-ups. Since we use cohort data, we have for some start-ups data at different points in time. This allows us to analyze whether the effect of the availability of external capital on firm performance changes with increasing age of the firms. To measure the impact of external capital as a whole, we include separate indicators for debt and venture capital constraints. Using different performance measures, we find that debt constraints are not only a problem of the first years. While the negative impact of debt constraints on firm survival disappears with increasing age of the firms, profit is persistently negative affected by debt constraints. Debt constraints, however, do not impact employment growth of the firms, not even in the first years. The availability of venture capital is of lower relevance for the post-entry performance. Surviving and growth of the start-ups is not affected by venture capital constraints. However, firms with limited access to venture capital persistently have problems to attain profit break-even.
\end{abstract}




\section{Introduction}

Start-ups positively impact economic growth and development (e.g., Audretsch et al. 2006, Gries \& Naudé 2008). They are important drivers of aggregate innovation and productivity (see Aghion et al. 2006). Many of the new firms, however, fail in the initial years of life. Given the economic and social relevance of start-ups, it is important to better understand the factors of firm success.

Start-ups generate only limited cash flows and seed capital is often too limiting for these firms. Success of start-ups should thus strongly depend on access to external capital. However, particularly small and young firms face large problems to get external capital (e.g., Hallberg 2000, World Bank 2004, Angelini \& Generale 2008). An important reason for these financial constraints is the asymmetric information between the owners of the start-ups and external investors (e.g., Stiglitz \& Weiss 1981, Binks \& Ennew 1996). With increasing age of the firms, outside investors get additional information about the quality of firms and can adjust, according the lower level of asymmetric information, the terms of the financing contracts. In accordance with Brito \& Mello (1995), we expect that for more mature firms, costs of external capital are lower and loan sizes less limited. Accordingly, the impact of financial constraints on performance should decrease with increasing age of the firms.

While many studies deal with policy implications to reduce the problems of financial constraints (e.g., OECD 2004, 2005, World Bank 2006, European Commission 2007), the importance of financial constraints is unclear. Only a few studies empirically analyze the impact of financial constraints on success of start-ups. In this work we investigate the relationship between financial constraints and start-up success. In our model we describe firm success using three different dependent variables: (a) firm survival, (b) a dummy variable measuring if a firm has attained profit break-even and (c) growth of employment. Further, to analyze the impact of the availability of external capital as a whole, we include separate measures of financial constraints for (a) financial debt and (b) venture capital. In a second step, we then investigate whether the effect of financial constraints is persistent with increasing age of the firms. So far no study empirically analyses the persistence of the impact of financial constraints. Such an analysis is important to understand the problem of financial constraints better, and thus to draw adequate policy implications.

We formulate the following two hypotheses: (a) a limited access to external financial capital reduces a firm's incentives to innovate and improve its productivity, what negatively affects the 
success of the firm and (b) the effect of financial constraints on the success of the start-ups is strongest in the first years after firm foundation.

The population we use in this study refers to the cohort of Swiss enterprises which were founded between 1996 and 1997. In the beginning the cohort included 7112 firms. This cohort was registered by the Swiss Federal Statistical Office and contains all "green-field" start-ups (i.e. mergers and manager-takeovers are not included) which were founded in this period. Among these firms three surveys were conducted, the last one in 2006, nine to ten years after firm foundation.

Since some firms left the sample between two cross-sections, the use of cohort data entails the potential problem of selective attrition. In order to address this problem, we use different tests and correct our estimates by applying a special weighting approach. A further problem may be that financial constraints reflect low quality of the firms, in which case our estimates would suffer from an endogeneity bias. To capture different effects on firm success we include the financial variables in an extensive base model. Further, we test for endogeneity of the financial variables and cannot reject the null hypothesis of exogenous variables in any case.

Compared to other research our study has primarily two new elements. Following a cohort of new firms enables us to analyze the impact at different stages in the development of the start-ups. Thus, we cannot only test if success of start-ups is affected by financial constraints, but also whether this effect disappears when these firms grow older. So far there is no empirical study using data for a cohort of new firms to analyze the determinants of success. A second feature is the wide spectrum of variables that could be taken into account in the model specification, particularly to measure financial constraints and success of start-ups. This allows us to analyze what kind of success is affected by which type of financial constraints.

We find that debt constraints do negatively affect surviving of start-ups in the early stage. With increasing age of the firms this effect disappears. The impact on surviving the period six to nine years (seven to ten years respectively) since the firms' foundation is not significant anymore. On the other hand, constraints persistently impact profit. The probability to attain profit break-even in all three cross-sections is significant negative correlated with debt constraints. Further, we find no evidence that employment growth is affected by debt constraints. Post-entry performance is less affected by venture capital constraints. While the probability to attain profit break-even is also negatively affected by venture capital constraints, the availability of venture capital is not correlated with survival and growth.

The remainder of the paper is organized as follows: Section 2 presents the conceptual background of the empirical analysis. Section 3 describes the database and financial constraints of the start-ups using descriptive statistics. Section 4 contains specifications of the empirical 
framework used to describe the success of the firms. Section 5 presents the estimation results. Section 6 contains a comparison with results of similar studies. Section 6 summarizes results and discusses policy implications.

\section{Conceptual background}

The aim of this paper is to model the relationship between success of start-ups and external financial restrictions, embedded in a model of determinants of success. Our conceptual framework builds upon the strategic management literature, which suggests that the performance of a firm depends on a firm's environment (external analysis), as well as on a firm's internal characteristics (internal analysis) (see Barney 1991). External analysis focuses on analyzing a firm's opportunities and threats within its competitive environment (e.g., Caves \& Porter 1977, Porter 1980, 1985). In the resource-based view the individual firm resources - including human capital, physical capital and organizational capital resources - enable the firm to create and implement strategies that improve its competitiveness (see Barney 1991).

Since the impact of financial constraints on different aspects of firm success may differ, it makes sense to estimate a model of firm success for different dependent variables. In our framework we use three measures of success: (a) firm survival, (b) to describe a firms' activity level we use a variable measuring if a firm has attained profit break-even ${ }^{1}$ and (c) employment growth. While survival and profit both measure financial success, employment growth describes the expansion trend of the firms. We expect that independent variables have an impact on firm success in general. Therefore, we speak in the following of firm success in general, but keep in mind that the effect may depend on the "type" of success.

Following the theoretical literature, and in accordance with empirical studies (see, e.g., Brüderl et al. 1992, Stearns et al. 1995, Marmet 2006 and Saridakis et al. 2008 for a similar approach), we define a base model including five categories of variables that may influence the success of startups. To analyze the impact of financial constraints on firm success we add as a sixth category some financial variables.

\section{Founder characteristics. MAIN, UNEMPLOY, LAGE, GENDER}

Different aspects of the founder characteristics may have an impact on firm success. A first point is the motivation for creating a new firm. Motivation theory differs between push and pull motives (e.g., Johnson 1986, Gartner et al. 1992, Schjoedt \& Shaver 2007). Expectation of

\footnotetext{
${ }^{1}$ Sales of these small firms are extremely volatile. The volume of sales at a certain point in time is thus not a representative measure of a firms' activity level. Further, as small firms often do not require audited financial statements, the exactness of absolute sales data is ambiguous. Therefore, we use profit break-even instead of absolute sales data to describe a firms' activity level.
} 
increased life satisfaction pulls people toward firm foundation, whereas possible reduction of job dissatisfaction pushes them toward founding a start-up (Schjoedt \& Shaver 2007, p. 735). We expect that firm founding as an act from necessity is negatively correlated with firm success. In our model we measure the "push effect" by including the employment status of the firm owners before firm creation (UNEMPLOY).

Further, a founder's dedication to the firm and the seriousness of the founded firm could impact the success. According to Brüderl et al. (2007) a variable measuring whether founders working on a regular basis (MAIN) captures this effect (Brüderl et al. 2007, p.194). Finally, we also include variables for gender (GENDER) and average age (LAGE) of the founders. Age can be seen as a proxy for professional experience of the founders, what would indicate a positive correlation with firm success. On the other hand, some age-related decisions such as exits to go into retirement negatively affect the current success measures of the firms. Since age-related exits are probably not caused through lack of success, such exits may distort the use of SURVIVAL as success measure. LAGE should capture this effect of voluntary firm exits in the survival models. ${ }^{2}$ GENDER controls for effects through gender specific skills (e.g., Cooper et al. 1994).

\section{Human capital. QUAL}

In the initial years start-ups do not have much time to make and adjust decisions. Through formal education, people acquire skills which help to recognize opportunities in the surrounding environment (Baptista et al. 2007, p. 9). Thus, we expect that firms which have employees with tertiary education (QUAL) are more successful.

\section{Strategy variables. R\&D, NP, MP}

Innovation variables measure the ability of a firm to use its resources to create capabilities (see Audretsch \& Mahmood 1995). According to Buddelmeyer et al. (2009) effects on success may differ between innovation input and output. While innovation output by itself is a successful innovation, current innovation investments implicate a certain risk of failure, what indicates more uncertain returns. To completely capture innovation effects, we include in our model measures of innovation output as well as of innovation input. Innovation output is measured by the introduction of new (NP) and modified products (MP). R\&D activities (R\&D) indicate innovation input. We expect that innovation output is positively correlated with firm success, while innovation input may have a negative impact.

\section{Market conditions. PCOMP, NPCOMP}

\footnotetext{
${ }^{2}$ We have also tried to capture this effect by including a single age dummy. However, these dummies did not perform very well. It seems that age related decisions are not correlated with a unique age threshold wherefore a linear age variable performs better than a single dummy. To capture at the same time the effect of professional experience and age related decisions, we alternatively estimated the models with different dummies (see footnote 9).
} 
The intensity of competition differs among stages of an industry's life cycle. The expectation of industry life cycle models is that in an early stage, firms compete on product differentiation. As industries mature, products of different firms get more similar and competition shifts from product innovation to process innovation (e.g., Utterback \& Abernathy 1975, Adner \& Levinthal 2001, Cusumano et al. 2006). For start-ups it should be easier to establish and maintain a competitive advantage in the market in early stages. We expect a positive impact of the intensity of non-price competition (NPCOMP) on firm success and a negative effect of the intensity of price competition (PCOMP).

Firm variables. LCAP, Legal form, LSIZE

It depends on the legal form of a company to what extent founders are liable in case of failure. Stiglitz \& Weiss (1981) show that founders of firms with limited liability are primary interested in projects with a high anticipated return, while the risk of failure is of lower importance. We expect that firms operating under full liability (sole proprietorship) realize lower growth rates than firms with limited liability $(\mathrm{AG}, \mathrm{GmbH})$. The impact on financial success is not a priori clear. As Harhoff et al. (1998) find in a study for Germany, full liability may positively impact voluntary exits and thus correlate negatively with firm survival.

The "liability of smallness" hypothesis assumes that business size affects firm success because larger firms have more resources to manage bad times (e.g., Aldrich \& Auster 1986, Brüderl 2007). In accordance with this hypothesis, a firm's financial strength serves as a buffer against external shocks. Further, a certain internal financial buffer reduces dependence on external capital. We expect a positive impact of firm size (LSIZE) and volume of seed capital (LCAP) on firm success.

\section{Financial constraints. DEBT_CONST, VC_CONST}

Because internal financing is often too limiting for start-ups, entrepreneurs look for external capital. There are primarily two sources of external capital, financial debt and external sources of equity capital. However, since particularly small and young firms face large problems to get such external capital (e.g., Hallberg 2000, World Bank 2004, Angelini \& Generale 2008), start-ups tend to be financial constrained.

According to the literature, financial constraints are caused through asymmetric information between the owners of the start-ups and outside investors (e.g., Stiglitz \& Weiss 1981, Binks \& Ennew 1996). There are several reasons for a high level of asymmetric information. Firstly, startups have no track record, what directly impacts evaluation costs. A study of the World Bank finds that the availability of credit history information reduces processing time, processing costs and default rates of credit bureaus by more than 25 percent (World Bank 2006, p. 13). Secondly, as small firms often do not require audited financial statements, start-ups do not have much 
publicly visible information. Under these circumstances, it is difficult for outside investors to evaluate the creditworthiness of start-ups. Given the high failure rate of these firms, agency costs of external capital relative to capital size can be substantial (Huyghebaert \& Van de Gucht 2007, p. 102). As a consequence, for start-ups access to external capital may be expensive or even limited.

In the case of innovative start-ups, asymmetric information is not the only reason for financial constraints. Innovative start-ups may have problems to get debt capital, even if asymmetric information is limited. Because innovative start-ups sell new products, it is difficult to judge whether their innovations will be successful on the market or not. Venture capital can solve this problem of high risk. In exchange for the high risk that venture capitalists assume by investing in innovative start-ups, venture capitalists usually get a significant portion of the company's ownership - share on upside returns compensate for high risk. Further, venture capitalists mostly have sector-specific expertise which enables them to better evaluate the risk of an investment. Thus, for innovative start-ups primary access to venture capital is important. The availability of venture capital, however, is strongly limited, even more in Switzerland. As a study of the OECD shows, the Swiss venture capital market is small. Venture capital expenditures are just above the OECD average and only a part of it is used as early-stage capital to finance start-ups (OECD 2008, p. 156).

When access to new external capital is limited, a firm will have problems to implement strategies that improve its productivity (see Holtz-Eakin et al. 1994, Aghion et al. 2007). If a firm raises new external capital anyway, it will be expensive. Thus, capital constraints should have a negative effect on firm success. To analyze the impact of different forms of financial constraints we distinguish between debt constraints (DEBT_CONST) and problems to get venture capital (VC_CONST).

Our measure of debt constraints (DEBT_CONST) bases on three different dimensions: importance of unfavorable credit conditions (CRED_COND), importance of a too low credit line (CRED_LINE) and importance of insufficient information about debt financing options (DEBT_INFO). The overall variable DEBT_CONST is calculated as the sum of the standardized values (average 0 , standard deviation 1) of the three detailed variables. We analyze the effect of debt constraints using the overall as well as the detailed variables. Which dimension of debt constraints impact the different success measures is not a priori clear. The credit conditions (CRED_COND) may have a stronger impact on financial success, while quantitative restrictions (CRED_LINE, DEBT_INFO) primarily should affect the expansion trend. On the other hand, quantitative restrictions of new capital may disable the realization of necessary investments and so impact the efficiency of the firm immediately, what would indicate a negative effect on 
financial success. In the literature we can find an additional argument for a negative correlation of quantitative credit restrictions and firm survival. Brüderl et al. (2007) argue in accordance to the "liability of smallness" thesis that firms which have no problems to get external capital should have less trouble to survive crises (Brüderl et al. 2007, pp. 62-3). External capital serves as a buffer to withstand external shocks and longer periods without sales.

We expect a negative impact of financial constraints (DEBT_CONST, VC_CONST) on financial success and expansion trend. In the case of debt constraints it is not a priori clear which dimension primarily determines this effect and the effect may differ among the various success measures. Because of increasing financial flows and a decreasing level of asymmetric information, success of older firms should be less affected by financial constraints (see Brito \& Mello 1995). Further, a track record reduces the risk of an investment in innovative firms. With increasing firm age, innovative firms should also get access to other sources of external capital and the dependence on the availability of venture capital should decrease. We expect that the effect of financial constraints on firm success decreases, or rather disappears, with increasing age of the firms.

To capture industry specific effects, we further include dummies controlling for industry affiliation.

\section{Description of the Data}

\subsection{Construction of the data set}

The population we use in this study refers to the cohort of Swiss enterprises which were founded between 1996 and 1997. In the beginning the cohort included 7112 firms. This cohort was registered by the Swiss Federal Statistical Office and contains all "green-field" start-ups (i.e. mergers and manager-takeovers are not included) which were founded in this period.

$3288(46.2 \%)$ of these start-ups were still in business in 2000. Among the firms that still existed by that time, the KOF collected data by means of a postal survey. $49.4 \%$ (1625) of the firms answered the questionnaire. $1339(82.4 \%)$ of these firms survived the next three years. In 2003 a follow-up survey was conducted among these firms. Answers were received from $70.6 \%$ (945) of the firms. In 2006, nine to ten years after the firm foundation, 857 (90.7\%) of the participants of the 2003 survey still existed. 73.5\% (630) of them were willing to fill out a third questionnaire. For some firms we thus have data at different points in time. For firms which dropped out of the sample we know whether the firm still existed at time of drop out and also whether the firm survived the following period. 
The KOF questionnaire covered questions about basic firm characteristics, firm performance and activity level, resource endowment, innovative activities and the market environment. ${ }^{3}$ What we are most interested in is the information about financial constraints. In 2000, the questionnaire included some additional questions about the founder characteristics (e.g., gender, age, education, experience and the wealth of the firm founders).

\subsection{Characteristics and development of the start-ups 1996/1997-2006}

Most of the start-ups in the data set are firms in the service sector (see Table A.1 in the Appendix). In each point of time they represent about $83 \%$ of the observations. About $9 \%$ belong to the construction sector, the remaining $8 \%$ to the manufacturing sector. These shares remained almost constant during the period 2000-2006. In the service sector the sub-sector of modern (knowledge-intensive) services (e.g., banking and insurance, business services) has a larger share than the sub-sector of traditional services (e.g., trade, hotels and catering); the share of modern services increased considerably between 2000 and 2006. In the manufacturing sector there are more low-tech than high-tech start-ups.

The observed start-ups are for the most part small firms. In each survey more than $80 \%$ of the enterprises employed less than five employees (measured in full-time equivalents). The average firm size only slightly increased from one period to the next. While in 2000 the firms had on average a size of 2.6 employees, the average size increased to 3.3 employees in 2003 and 4.8 employees in 2006. In 2006, ten years since their foundation, only $6.7 \%$ of the firms employed more than ten employees.

We find that a big part of the start-ups are strongly debt constrained (see Table 1). On average nearly $20 \%$ of the firms said that access to new debt capital strongly constrained their development. Asymmetric information between firm owners and outside investors seem to be a serious problem for the start-ups in our sample. As expected, innovative firms have more problems to get debt capital. Debt constraints (DEBT_CONST) of firms with R\&D activities are statistically significant higher than the constraints of firms without R\&D activities. Although venture capital is primary to finance innovative start-ups, the availability of venture capital constrained about $10 \%$ of the firms. Brito \& Mello (1995) expect that asymmetric information is primarily a problem of the initial years. In fact, financial constraints of the start-ups in our sample decrease with firm age. While in 2000 debt constraints were for $19.4 \%$ of the firms of high importance, the share decreased to $15.1 \%$ in 2003 and $14.5 \%$ in 2006 . At the same time, the share of venture capital constrained firms decreases from $10 \%$ in 2000 to nearly $6 \%$ in 2006 . The

\footnotetext{
3 The questionnaires are available in German, French and Italian at http://www.kof.ethz.ch/surveys/structural/panel.
} 
decrease is not only caused through sample selection. We can also observe decreasing financial constraints when we include solely firms which answered all three questionnaires (see Table 2).

\section{Econometric framework}

\subsection{Model specification}

To capture different aspects of firm success we estimate our model using three different dependent variables. To describe financial success we use the variables SURVIVAL and BREAK. SURVIVAL is a binary variable measuring whether a firm does or does not survive the next three years. BREAK is a dummy variable measuring if a firm has attained the profit breakeven point. GROWTH, the change of the natural logarithm of the number of employees over a period of three years, indicates the expansion trend of a firm. ${ }^{4}$

To explain firm success we include all variables of our base model presented in section 2 and add as an additional category the variables measuring financial constraints (for a detailed definition of the variables we refer to Table 3). Firm survival, profit break-even and growth are described by the same set of independent variables. To test the robustness of our model, we alternatively estimated the equations including only variables which had a statistically significant effect in the particular success model. While this strongly increased the model quality, it had only a marginal effect on the estimation results.

\subsection{Econometric procedure}

To take into account the binary character of the two dependent variables measuring firm survival (SURVIVAL) and whether a firm attained profit break-even (BREAK) we estimate probit models. To estimate employment growth (GROWTH) we use ordinary least squares. For GROWTH and BREAK we estimate separate models for each of the three cross-sections 2000, 2003 and 2006. Since we have no survey data for 1996/97, we cannot model firm survival between 1996/97-2000 and we estimate only models for survival between 2000-2003 and 20032006. Each cross-section reflects a further stage in the development of the start-ups. Thus, differences of the results over these three points in time should represent different effects on firm success at different development stages. However, as the surrounding environment probably also changes over time (time effect), it is not a priori clear whether different effects between different cross-sections are driven by increasing age of the firms (age effect). The most important factors to describe such time effects are probably business fluctuations. The availability of external

\footnotetext{
${ }^{4}$ In accordance with the literature (see, e.g., Evans 1987, Harhoff \& Stahl 1995, Nerlinger 1998), we assume that growth of start-ups in our sample follows an exponential growth process. Therefore, we take the natural logarithm of the number of employees.
} 
capital should be positive correlated with the business cycle. In Switzerland, the years 1996-2000 and 2003-2006 were periods of economic growth, while 2000-2003 were through years of the business cycle. When time effect would dominate the age effect in our model, the impact of financial constraints should remain significant in the second period, but should disappear in the third period.

Models include for all three success variables the same independent variables. However, we do not describe the different success variables with data of the same cross-sections. Firms which did not survive a certain period did not answer our questionnaire at the end of this period. Therefore, we have to include the data of the previous cross-section to describe firm survival between two cross-sections. For GROWTH and BREAK we include, with the exception of the number of employees, the data at the end of the same period. Due to multicollinearity we have to conduct separate estimates for the different variables measuring financial constraints (see correlations in Table A.9). The base model is not affected by multicollinearity.

\section{Testing for selective attrition}

Between two subsequent surveys some firms disappeared from the market and some other did not want to participate to our survey anymore. The question is whether the remaining samples are still representative. When determinants of selection are correlated with our success measures attrition is selective, and traditional econometrical techniques will lead to biased and inconsistent estimates.

When a firm refused to answer a questionnaire, we only know if this firm still existed, but we have no observations for the other variables in our models. Thus, the selection equation and the strategy equation cannot be identically specified and we cannot use a Heckman procedure to detect a potential selection bias (see Wooldridge 2002a, Briggs 2004).

In the survival models we only have attrition through non-response. Because we know for firms which answered the previous questionnaire, as well as for firms which did not answer the questionnaire, if they survived the following period, we can analyze whether the survival probability is statistically significant different for respondents than for non-respondents. Using chi-square tests, we find no evidence for a selection bias. ${ }^{5}$

In the growth and profit break-even models data may suffer from selective attrition through both non-response and non-survival. Following Wooldridge (2002a, p. 581) a test for selective attrition is to insert a selection indicator as an additional explanatory variable in our base model, run the regression and test the significance of the coefficient of the selection indicator. As a

\footnotetext{
${ }^{5}$ Further, we also analyzed the impact of attrition on survival using multiple regression models. Since we have only some basic data for firms which did not answer our questionnaire, the model quality was not good enough to interpret the relevant coefficients.
} 
selection indicator we use the dummy variable INSAMPLE that takes the value one if a firm is still in our sample in the following cross-section and zero if not. Because we have no such indicator for cross-section 2006, we can only apply this test for cross-sections 2000 and 2003. Test results indicate that selective attrition may be a problem in the profit break-even models (see Table A.2). The coefficient of the selection variable for both cross-sections is significant. We cannot detect selective attrition in the growth models.

In our study it is primarily important to know whether attrition does affect the impact of financial constraints on firm success. By including interaction terms in our model, we estimate the impact of financial constraints on success separately for firms which left our sample during the course of the next three or six years respectively (future attritors) and firms which remained in our sample (future respondents). The first interaction term takes the value of DEBT_CONST (VC_CONST respectively) if the firm is still in the sample in the corresponding next cross-section and value zero if not. The second interaction term is defined vice versa (see Table 3 for a detailed definition of the variables). In the growth models the coefficients of the two interaction terms are not statistically different (see Table A.3 and Table A.4). Attrition seems only to have an effect on the coefficients of the financial variables in the break-even models. In these models, the negative impact of financial constraints on the probability to attain profit break-even tends to be larger for future attritors than for future respondents. Thus, the effect of financial constraints may be underestimated in the remaining sample. As the effect of financial constraints on profit breakeven is significantly negative in the remaining sample (see Table A.5), our conclusions do not seem to be affected by selective attrition.

Nevertheless, we correct our estimates for attrition bias by applying the inverse probability weighting approach (see Wooldridge 2002a, 2007). Following this approach, we estimate in a first step the probability that a firm has not disappeared so far (retention probability). In a second step we weight each firm with the inverse of this estimated probability. The idea is that firms which have a higher attrition probability are underrepresented in the sample and therefore get more weight in the models. Wooldridge shows that the weighted estimator is consistent if the assumption called "selection on observables" holds. Under this assumption a vector of variables observed for firms that are in the sample in the first period $t=1, z_{i 1}$, predicts selection at time $t$, so that all variables in the consecutive models at time $t,\left(\mathrm{y}_{\mathrm{it}}, \mathrm{x}_{\mathrm{it}}\right)$, are independent of selection (Wooldridge 2002a, p. 587). To allow the explanation of selection by past outcomes of ( $\mathrm{y}_{\mathrm{it}}, \mathrm{x}_{\mathrm{it}}$ ), $\mathrm{z}_{\mathrm{it}}$, we must further assume that selection at time $\mathrm{t}$ is independent of future values of $\mathrm{z}_{\mathrm{it}}$ and $\left(\mathrm{y}_{\mathrm{it}}, \mathrm{x}_{\mathrm{it}}\right)$. When $\mathrm{s}_{\mathrm{it}}$ is a selection indicator, where $\mathrm{s}_{\mathrm{it}}=1$ if $\left(\mathrm{y}_{\mathrm{it}}, \mathrm{x}_{\mathrm{it}}\right)$ are observed in period $\mathrm{t}$, the probability of selection then is defined as 
$P\left(s_{i t}=1 \mid v_{i 1}, \ldots, v_{i T}, s_{i, t-1}=1\right)=P\left(s_{i t}=1 \mid z_{i t}, s_{i, t-1}=1\right)$

where

$v_{i t} \equiv\left(y_{i t}, x_{i t}, z_{i t}\right)$

In our data we have a two-stage selection between two cross-sections. In a first stage, firms which did not survive a period exit our sample. In a second stage, firms which did not answer our questionnaire at the end of the period drop out. The retention probability equals the probability to get an answer $\left(\mathrm{ANSWER}_{\mathrm{it}}=1\right)$, conditional on the probability that the firm still exists in that period (SURVIVAL $\left.\mathrm{S}_{\mathrm{it}}=1\right)$. To calculate the probabilities of the different outcomes we estimate a multinomial probit model (see Kapteyn et al. 2006 for a similar approach). ${ }^{6}$ The retention probability then can be calculated as

$P\left(\right.$ ANSWER $\left._{i t} \mid S_{U R V I V A L}\right)=\frac{P\left(\text { ANSWER }_{i t} \cap S U R V I V A L_{i t}\right)}{P\left(S U R V I V A L_{i t}\right)}=\frac{P\left(\text { ANSWER }_{i t} \cap S U R V I V A L_{i t}\right)}{1-P\left(N_{N S S U R V I V A L}\right)}$

We assume that the response behavior depends on the same determinants as firm survival. In a first step we used the whole success model to estimate the multinomial probit model. To increase the quality of our estimates, we excluded in a second step insignificant variables. Estimation results are presented in Table 4.

Following Wooldridge (2002a, p. 589), in cases where attrition is an absorbing state ${ }^{7}$, the probabilities used in the inverse probability weighting procedure can be calculated as

$\hat{P}_{i t} \equiv \hat{\pi}_{i 2} * \hat{\pi}_{i 3} * \ldots * \hat{\pi}_{i t}$

where

$\hat{\pi}_{i t} \equiv P\left(A N S W E R_{i t}=1 \mid z_{i t}, A_{N S W E R_{i t-1}}=1\right)$

In other words, we estimate multinomial probit models at each time $t$, including variables observed for all units in the sample at $\mathrm{t}-1$.

To correct our estimates for attrition bias, we finally weight our objective function by $1 / \hat{P}_{i t}$. When we compare our results with Tables A.4 and A.5, we see that this procedure has only a marginal impact on the results. This confirms the test results in the beginning of this section.

\section{Testing for endogeneity}

A further potential problem is endogeneity. Endogeneity would imply inconsistent estimations. Since we have in our models a lag between dependent and independent variables, our results should not be affected by endogeneity. However, when we assume that external capital owners

\footnotetext{
${ }^{6}$ The multinomial probit procedure seems to be superior to a multinomial logit because it does not assume independence of irrelevant alternatives (IIA) (Greene 2003, p. 727).

${ }^{7}$ Once a firm drops out of the sample, the firm is out forever.
} 
are able to predict future developments of start-ups, endogeneity may be a problem anyway. However, it is not absolutely clear how important a firm's quality is to get external capital. As external capital in general is limited and because of asymmetric information, even firms with a high potential may have problems to get external capital. The fact that in our data set the correlation between dependent variables and financial constraints is in each case bellow 0.2 strengthens this argument (see Table A.9). Since we control for different aspects of firm quality, endogeneity should not be a problem in our model.

To test for endogeneity we apply the Rivers-Vuong-Test (Wooldridge 2002b, p. 483), which tests the null hypothesis that the financial variables are exogenous. In a first stage, we thus estimate instrument equations for the financial variables separately for each cross-section. All instruments in our instrument equations fulfill the required conditions: they are correlated with the dependent variable in the instrument equation but not with the dependent variable in the structural equation (success equation) and they are not correlated with the residuals of the endogenized success equation. In accordance with Wooldridge (2002b), we further test the over identifying restrictions (Wooldridge 2002b, pp. 484-5). All instruments pass this test. In a second stage, we include the residuals of the first stage in our success equations. To correct the standard errors of the estimated parameters we use bootstrapping. Under $\mathrm{H}_{0}$ the residuals of the instrument equations and the residuals of the second stage equations are uncorrelated.

Testing each financial variable separately would imply 45 tests. To reduce the number of test to a practicable number, we test for each cross-section only the overall variables DEBT_CONST and VC_CONST. ${ }^{8}$ Since the tests of endogeneity and tests of over identifying restrictions are conducted only after unweighted estimations, we test without correcting our estimates for selective attrition. Using our instruments, we cannot reject the null hypothesis of exogenous variables in any case (see Table 5 and Table 6).

For cross-sections 2003 and 2006 we further conducted a weak test on endogeneity by lagging the financial variables by one period. In general, the additional time lag does not change the impact of the variables on firm success. Despite the large time lag, only the impact of the two variables measuring credit conditions (CRED_COND) and venture capital constraints (VC_CONST) on profit break-even is not significant anymore in cross-section 2003.

\section{Estimation results}

Control variables impact firm success as expected (see Table 7,8 and 9 respectively). The average age of the firm founders (LAGE) seems to capture the retirement effect - the impact of

\footnotetext{
${ }^{8}$ In further estimates not presented here, we tested some of the detailed variables for endogeneity. In all cases these tests confirmed the test results for the overall variable.
} 
LAGE in each model is negative. ${ }^{9}$ While innovation output (NP, MP) in most models is positive correlated with firm success, we find a negative impact of R\&D on profit. Limited liability (AG, $\mathrm{GmbH}$ ) has a negative effect on profit, but positively impacts survival and growth of the firms.

The impact of financial constraints differs among dependent variables. Thus, we discuss the effects on survival, profit and growth separately.

Firm survival. Debt constraints play an important role for firm survival in the first years after the firms' foundation. CRED_COND, CRED_LINE as well as the overall variable DEBT_CONST have a statistically significant negative impact on the survival of start-ups between the years 2000 and 2003 (see Table 7). Only DEBT_INFO added to the base model does not have a significant coefficient in this period. For the survival of the start-ups it seems to be irrelevant if the quantity of debt capital is restricted, or if debt capital is linked with high costs. In further estimates not presented here, we analyzed the threshold for the effect of financial constraints on success by using dummy variables. We found that the impact on survival is only statistically significant if debt constraints are of high importance (value 4 or 5 on respective five-level Likert scale). On the other hand, venture capital constraints (VC_CONST) have no effect on firm survival, not even on the survival of firms with $\mathrm{R} \& \mathrm{D}$ activities. ${ }^{10}$ This is surprising, since innovative firms tend to have more problems to get debt capital and should thus be more dependent on the availability of venture capital. An explanation for this insignificant effect could be that, as Switzerland is short of venture capital for start-ups (see OECD 2008), most founders do not expect to get venture capital after firm foundation. Thus, the low availability of venture capital in Switzerland may discourage firms to enter the market, but does not affect firm survival afterwards.

As expected, the effect of debt constraints on firm survival disappears with increasing age of the start-ups. Surviving the years 2003-2006 is not affected anymore by financial constraints of the previous period. As 2000-2003 were through years of the business cycle, the availability of external capital should be even more limited in this period. Since the impact of financial constraints on firm survival disappears in this period, we conclude that the different effects between cross-sections are driven by increasing age of the firms and not by changes in the surrounding environment - age effects dominate time effects.

Profit break-even. Debt constrained firms have more problems to attain the profit break-even point. As in the models for firm survival, we cannot find different effects for different

\footnotetext{
${ }^{9}$ Further tests with dummies showed that the impact of professional experience on performance is in general weak. Only surviving the period 2000-2003 is positively affected by an increasing age up to a certain level.

${ }^{10}$ To estimate the impact of VC_CONST for firms with R\&D activities we included two different dummy switching variables in our model (same procedure as used in Table A.3). The first one measured the effect of VC_CONST for firms with $R \& D$ activities, the second one for firms without $R \& D$ activities.
} 
dimensions of constraints. All measures of debt constraint have a significant negative impact on profit (see Table 8). Compared with firm survival we identified a lower threshold for the effect of debt constraints on profit break-even. While firm survival is not affected by low debt constraints (value 2 or 3 on respective five-level Likert scale), they negatively impact profits. The negative impact is significantly larger for higher constrained firms (value 4 or 5 on respective Likert scale). Venture capital constraints do also negatively impact the probability to attain profit breakeven. However, the threshold is higher than for debt constraints. Only firms with large venture capital constraints (value 4 or 5 on respective Likert scale) have problems to attain profit breakeven. $^{11}$

Rather unexpected, the negative impact of financial constraints on profit in all three crosssections remains significant. However, this is further evidence that changes in the surrounding environment are of low importance in our model. Despite economic growth in the period 20032006, the impact of financial constraints remains significant. Instead, it seems that asymmetric information ten years since the firms' foundation still is large enough to affect profit, but does not impact survival anymore. An explanation for the still large asymmetric information could be that most of the firms remained small, even ten years since the firms' foundation (see Table A.1). As information collection of small firms relative to the loan size is more costly, external capital owners will hesitate to lend money to small firms. Since the biggest firms in our sample also remained quite small, it is hardly possible to test this explanation. It is thus no surprise that we found no statistically significant different effects for smaller firms when DEBT_CONST was interacted with firm size. ${ }^{12}$

Employment growth. Employment growth of the start-ups is not affected by debt constraints. Only the variable DEBT_INFO has a statistically significant negative effect on growth in the second period (see Table 9). There could be different reasons for this unexpected result. Firstly, employment growth of the firms is limited (see Table A.7). Therefore, growth should be possible without additional infrastructure, and no additional external capital is needed. Secondly, about 80 percent of the firms in our sample are firms in the service sector (see Table A.1). Firms in this

\footnotetext{
${ }^{11}$ External capital constraints measure dependence on external capital as well as availability of external capital. BREAK is directly correlated with the availability of internal capital and thus with the dependence on external capital. The impact of financial constraints on BREAK could thus be driven by the dependence on external capital, while access to external capital would be of low importance. To test this hypothesis, we estimated the impact of financial constraints separately for different levels of internal capital availability. Despite correcting for internal capital availability, financial constraints significantly affect attaining profit break-even.

12 DEBT_CONST was interacted with the metric variable LSIZE. Because of the low variance of firm sizes, we alternatively used two different dummy switching variables (same procedure as used in Table A.3). The first one differed between the largest $10 \%$ of the firms in the sample and the rest, while the second one differed between the largest $5 \%$ and the rest.
} 
sector are generally characterized by low capital intensity. We thus expect that, if additional infrastructure is required, expenditures are limited.

Venture capital constraints also do not affect growth of start-ups.

\section{Comparison with existing empirical literature}

Two studies deal with the impact of liquidity constraints on the success of start-ups using firm level data. Saridakis et al. (2008) analyze the survival of young firms based on English data conducted in 2001. They find that firms which were liquidity constrained at start-up are less likely to survive. Similar to the results of our study, survival is only affected if firms had serious financial problems. Using the same data, Saridakis et al. (2007) show that liquidity constraints do not significantly impact growth of these firms.

Given the expectation that firms with wealthier entrepreneurs are less financial constrained, Hvide \& Møen (2008) analyze the impact of entrepreneur wealth on start-up performance in Norway. They find that wealth of entrepreneurs before firm foundation is positively correlated with firm survival and profitability on assets. Additional wealth, however, has only a positive impact up to a certain wealth level. If this level is exceeded, additional wealth has no significant impact on firm survival anymore. In the case of profitability, the impact of additional wealth is even negative in the upper 25 percent of wealth distribution. According to the authors, reason for such an effect could be that entrepreneurship is a luxury good and wealthy entrepreneurs prefer non-pecuniary benefits, such as independence, to an increasing income.

In a cross-country study Aghion et al. (2007) analyze the effect of the financial development of a country on post-entry employment growth of new firms. They find that new firms grow faster in countries with more developed financial markets. Further, they find some evidence that financial development has a stronger impact on growth of new firms compared to incumbents.

A second category of empirical studies analyzes the impact of financial constraints on firm performance not just including start-ups. Because start-ups have quite different characteristics than established firms, a direct comparison with the results of these studies is difficult.

Becchetti \& Trovato (2002) find in a study based on Italian survey data that firms which asked and did not receive a credit have significantly lower rates of employment growth.

Using a panel of French firms, Musso \& Schiavo (2008) analyze the impact of financial constraints on firm survival and growth. In this data set firms with financial constraints have a significantly lower probability to survive and have significantly lower growth rates in terms of sales, capital stock and employment. Rather unexpected, growth of productivity in the short run 
is positively affected by financial constraints. They argue that financial constrained firms cannot buy new infrastructure and are thus forced to cut costs to remain on the market.

In a cross-country analysis based on survey data Ayyagari et al. (2008) show that financial obstacles are negatively correlated with sales growth of firms. Analyzing the impact of specific financial obstacles, they find that primarily high interest rates constrain the growth of the firms, but also banks' lack of money to lend matters. Quantitative restrictions as well as capital costs affect firm survival, which is compatible with the results of the present study. By including an interaction term, they further show that in smaller firms financial constraints have a stronger impact on sales growth.

In a cross-country analysis based on industry level data Rajan \& Zingales (1998) find a positive correlation of the financial development of a country and the average employment growth of the industry.

Finally, Hotz-Eakin et al. (1994) analyze the impact of liquidity on survival and earnings of firms. They use US individual tax return data of self-employed people. By including only individuals who received inheritances, they find that the size of an inheritance is positively correlated with the probability that an entrepreneur will stay in business and also has a positive impact on future receipts.

On the whole, our results are quite similar compared with those of other studies. In general, financial constraints negatively impact the performance of the firms. An exception is the finding of Saridakis et al. (2007). In accordance with our paper, they show that growth of start-ups is not affected by liquidity constraints.

\section{Conclusions}

We find that debt constraints persistently impact the success of start-ups. While ten years after firm foundation debt constraints do not affect firm survival anymore, constrained firms still have problems to attain profit break-even. The impact of debt constraints on different success measures decreases with increasing age of the firms, but does not disappear. On the other hand, the post-entry performance is less affected by venture capital constraints. Only the effect on profit break-even is statistically significant. As for debt constraints, firms with venture capital constraints persistently have problems to attain profit break-even.

Because of the economic importance of start-ups, it seems important to simplify access to debt capital. Public support for start-ups during the first years cannot solve the problem. Instead, asymmetric information in the financial market should be reduced to permanently improve 
access to debt capital. An OECD study discusses different policies to reduce asymmetric information (OECD 2004, pp. 23-41). In accordance with this study, governments should for example ensure an adequate supply of well qualified personnel to increase the quality of evaluations of a firm's credit worthiness. Encouraging credit bureaus to use new financial and information technologies would reduce the costs of evaluations. On the side of the young firms, governments could support the writing of business plans and financial projections. As we found in our study, it is further important to help firms to understand the different financing options they have.

Although in our analysis only one of three success measures is affected by venture capital constraints, it seems important to ease access to venture capital. While the effect on post-entry performance is limited, a small venture capital market may discourage innovative firms to enter the market. The OECD study analyses different policies to improve equity financing (OECD 2004, pp. 25-28). To increase the amount of available venture capital, governments could for example allow institutional investments (e.g., pension funds, insurance companies and banks) in venture capital funds, reduce capital gain tax rates and support business angel networks. Since governments do not have appropriate incentives, direct investments in venture capital funds do not seem to be very effective.

Despite possible policies to simplify access to external capital, the availability of external capital will remain limited. To reduce dependence on external capital it is important that start-ups optimize their costs.

\section{References}

Adner, R. and Levinthal, D. (2001). Demand Heterogeneity and Technology Evolution: Implications for Product and Process Innovation. Management Science, Vol. 47, No. 5: 611628.

Aghion, P., Fally, T. and Scarpetta, S. (2007). Credit Constraints as a Barrier to the Entry and Post-Entry Growth of Firms. Economic Policy, 22(52):731-79.

Aghion, P., Blundell, R., Griffith, R., Howitt, P. and Prantl, S. (2006). The Effects of Entry on Incumbent Innovation and Productivity. NBER Working Papers, 12027, National Bureau of Economic Research, Inc.

Aldrich, H.E. and Auster, E. (1986). Even Dwarfs Started Small: Liabilities o Size and Age and Their Strategic Implications. Research in Organizational Behaviour, 8: 165-198.

Angelini, P. and \& Generale, A. (2008). On the Evolution of Firm Size Distributions. American Economic Review, American Economic Association, Vol. 98(1): 426-38. 
Audretsch, D.B. and Mahmood, T. (1995). New-Firm Survival: New Results Using a Hazard Function. Review of Economics and Statistics, 77: 97-103.

Audretsch, D.B., Keilbach, M.C. and Lehmann, E.E. (2006). Entrepreneurship and Economic Growth. Oxford University Press, Oxford.

Ayyagari, M., Demirguc-Kunt, A. and Maksimovic, V. (2008). How Important are Financing Constraints? The Role of Finance in the Business Environment. World Bank Economic Review, Vol. 22, No. 3.

Baptista, R., Karaöz, M. and Mendonça, J. (2007). Entrepreneurial Backgrounds, Human Capital and Start-up Success. (July 2007). Jena Economic Research Paper No. 2007-045.

Barney, J. (1991). Firm Resources and Sustained Competitive Advantage. Journal of Management, 17(1): 99-120.

Becchetti, L. and Trovato, G. (2002). The Determinants of Growth for Small and Medium Sized Firms: The Role of the Availability of External Finance. Small Business Economics, Vol. 19: 291-306.

Binks, M.R. and Ennew, C.T. (1996). Growing Firms and the Credit Constraint. Small Business Economics, 8: 17-25.

Briggs, D.C. (2004). Causal Inference and the Heckman Model. Journal of Educational and Behavioral Statistics, 29(4): 397-420.

Brito, P. and Mello, A. (1995). Financial Constraints and Firm Post-Entry Performance. International Journal of Industrial Organisation, Vol. 13, 4: 543-565.

Brüderl, J., Preisendörfer, P. and Ziegler, R. (2007). Der Erfolg neugegründeter Betriebe: Eine empirische Studie zu den Chancen und Risiken von Unternehmensgründungen. Duncker and Humblot, Berlin.

Buddelmeyer, H., Jensen, P.H. and Webster, E.M. (2009). Innovation and the Determinants of Company Survival. Oxford Economic Papers, (forthcoming).

Caves, R.E. and Porter, M.E. (1977). From Entry Barriers to Mobility Barriers: Conjectural Decisions and Contrived Deterrence to New Competition. Quarterly Journal of Economics, 91: 241-262.

Cooper, A.C., Gimeno-Gascon, J.F. and Woo, C.Y. (1994). Initial Human and Financial Capital as Predictors of New Venture Performance. Journal of Business Venturing, 9: 371-395.

Cusumano, M., Kahl, S. and Suarez, F.F. (2006). Product, Process, and Service: A New Industry Lifecycle Model. MIT Working Paper 228.

European Commission (2007). Seed Finance for High-Growth SMEs Active in Eco-Innovation: Summary Report. European Commission, Brussels. 
Evans, D.S. (1987). Test of Alternative Theories of Firm Growth. Journal of Political Economy, 95: 657-674.

Gartner, W.B., Bird, B.J. and Starr, J.A. (1992). Acting as if: Differentiating Entrepreneurial from Organizational Behavior. Entrepreneurship, Theory and Practice, 16(3): 13-31.

Greene, W.H. (2003). Econometric Analysis. Prentice Hall, Upper Saddle River, New Jersey.

Gries, T. and Naudé, W. (2008). Entrepreneurship and Regional Economic Growth: Towards A General Theory of Start-ups. World Institute for Development Economic Research, Working Papers RP2008/70.

Hallberg, K. (2000). A Market-Oriented Strategy for Small and Medium Scale Enterprises. Discussion Paper 40, International Finance Corporation, Washington, DC.

Harhoff, D. and Stahl, K. (1995). Unternehmens- und Beschäftigungsdynamik in Westdeutschland: Zum Einfluss von Haftungsregeln und Eigentümerstruktur. Ifo-Studien, Vol. 41: 17-50.

Harhoff, D., Stahl, K. and Woywode, M. (1998). Legal Form, Growth and Exit of West German Firms: Empirical Results for Manufacturing, Construction, Trade and Service Industries. Journal of Industrial Economics, Vol. 46(4): 453-88.

Holtz-Eakin, D., Joulfaian, D. and Rosen, H.S. (1994). Sticking it Out: Entrepreneurial Survival and Liquidity Constraints. Journal of Political Economy, Vol. 102, 1: 53-75.

Huyghebaert, N. and Van de Gucht, L.M. (2007). The Determinants of Financial Structure: New Insights from Business Start-ups. European Financial Management, Vol. 13: 101-33.

Hvide, H.K. and Møen, J. (2008). Lean and Hungry or Fat and Content? Entrepreneur Wealth and Start-up Performance. Working Paper.

Johnson, P.S. (1986). New Firms: An Economic Perspective. Allen and Unwin, London.

Kapteyn, A., Michaud, P.C., Smith, J. and van Soest, A. (2006). Effects of Attrition and NonResponse in the Health and Retirement Study. IZA Discussion Papers 2246, Institute for the Study of Labor (IZA).

Marmet, D. (2006). Wann haben junge Unternehmen Erfolg? Eine empirische Analyse anhand einer schweizerischen Gründungskohorte. Dissertation der wirtschaftswissenschaftlichen Fakultät der Universität Zürich.

Musso, P. and Schiavo, S. (2008). The Impact of Financial Constraints on Firm Survival and Growth. Journal of Evolutionary Economics, Springer, Vol. 18(2): 135-149.

Nerlinger, E.A. (1998). Standorte und Entwicklung junger innovativer Unternehmen: Empirische Ergebnisse für West-Deutschland. Nomos, Baden-Baden.

OECD (2004). Financing Innovative SMEs in a Global Economy. OECD, Paris.

OECD (2005). OECD SME and Entrepreneurship Outlook: 2005 Edition. OECD, Paris. 
OECD (2008). OECD Science, Technology and Industry Outlook 2008. OECD, Paris.

Porter, M.E. (1980). Competitive Strategy. Free Press, New York.

Porter, M.E. (1985). Competitive Advantage: Creating and Sustaining Superior Performance. Free Press, New York.

Rajan, R. and Zingales, L. (1998). Financial Dependence and Growth. American Economic Review, 88: 559-86.

Saridakis, G., Mole, K. and Hay, G. (2007). Do Liquidity Constraints in the First Year of Trading Reduce the Likelihood of Firm Growth and Survival? Evidence from England. Working Paper, Institute for Small Business \& Entrepreneurship, Glasgow.

Saridakis, G., Mole, K. and Storey, D. (2008). New Small Firm Survival in England. Empirica, 35: 25-39.

Schjoedt, L. and Shaver, K.G. (2007). In Press/2007. Deciding on an Entrepreneurial Career: A Test of the Push and Pull Hypotheses using the PSED Data. Entrepreneurship Theory \& Practice, 31(6).

Stearns, T., Carter, N., Reynolds, P. and Williams, M. (1995). New Firm Survival: Industry, Strategy and Location. Journal of Business Venturing, 10: 23-42.

Stiglitz, J.E. and Weiss, A. (1981).Credit Rationing in Markets with Imperfect Information. American Economic Review, Vol. 71, 3: 393-410.

Utterback, J. and Abernathy, W. (1975). A Dynamic Model of Process and Product Innovation. Omega, 3(6): 639-656.

Wooldridge, J.M. (2002a). Econometric Analysis of Cross Section and Panel Data. The MIT Press, Cambridge, Massachusetts, London, England.

Wooldridge, J.M. (2002b). Introductory Econometrics. A Modern Approach. South-Western College Publishing, Thomson Learning, Mason, USA.

Wooldridge, J.M. (2007). Inverse Probability Weighted Estimation for General Missing Data Problems. Journal of Econometrics, vol. 141(2): 1281-1301.

World Bank (2004). World Development Report: A Better Investment Climate for Everyone. World Bank, Washington DC, Oxford University Press.

World Bank (2006). Expanding Access to Finance: Good Practices and Policies for Micro, Small, and Medium Enterprises. World Bank, Washington DC. 
Table 1: Importance of different dimensions of financial constraints

\begin{tabular}{|r|ccc|}
\hline \multicolumn{3}{|c|}{ Percentage of firms } \\
\hline High importance of debt constraints & & & \\
\multicolumn{1}{r|}{ unfavorable credit conditions } & 22.3 & 19.4 & 18.4 \\
credit line too low & 21.1 & 16.6 & 16.4 \\
insufficient information about debt financing & 13.2 & 9.5 & 8.0 \\
\hline \multicolumn{1}{r|}{ Average } & 19.4 & 15.1 & 14.5 \\
\hline High importance of venture capital constraints & 10.1 & 9.1 & 6.2 \\
\hline $\mathrm{N}$ & 1589 & 911 & 615 \\
\hline Year & 2000 & 2003 & 2006 \\
\hline
\end{tabular}

Notes: We transformed the five-level ordinal variables measuring financial constraints to binary variables (high importance: level 4 and 5; low importance: level 1, 2 and 3 of the original five-level variable).

Table 2: Importance of different dimensions of financial constraints for firms which answered all three questionnaires

\begin{tabular}{|r|ccc|}
\hline \multicolumn{3}{|c|}{ Percentage of firms } \\
\hline High importance of debt constraints & & & \\
\multicolumn{1}{r|}{ unfavorable credit conditions } & 20.2 & 18.0 & 18.4 \\
credit line too low & 19.2 & 16.4 & 16.4 \\
insufficient information about debt financing & 11.7 & 7.3 & 8.0 \\
\hline \multicolumn{1}{r|}{ Average } & 16.6 & 13.8 & 14.5 \\
\hline High importance of venture capital constraints & 8.1 & 8.0 & 6.2 \\
\hline $\mathrm{N}$ & 615 & 615 & 615 \\
\hline Year & 2000 & 2003 & 2006 \\
\hline
\end{tabular}

Notes: We transformed the five-level ordinal variables measuring financial constraints to binary variables (high importance: level 4 and 5; low importance: level 1, 2 and 3 of the original five-level variable). 
Table 3: Definition and measurement of model variables

\begin{tabular}{|c|c|}
\hline Variable & Definition/ measurement \\
\hline $\begin{array}{l}\text { Dependent variables } \\
\text { SURVIVING } \\
\text { GROWTH } \\
\text { BREAK }\end{array}$ & $\begin{array}{l}\text { Firm survives next three years yes/no } \\
\text { Change of the natural logarithm of the number of employees in the preceding } \\
\text { three years } \\
\text { Profit break-even point attained yes/no }\end{array}$ \\
\hline Independent variables & \\
\hline $\begin{array}{l}\text { MAIN } \\
\text { UNEMPLOY } \\
\text { LAGE } \\
\text { GENDER }\end{array}$ & $\begin{array}{l}\text { At time of firm foundation founder worked on regular basis yes/no } \\
\text { Founder was unemployed before firm foundation yes/no } \\
\text { Average age of the firm founders; natural logarithm } \\
\text { Gender of the firm founders: male/female } \\
\text { (value } 1 \text { : 'male'; value 0: 'female'; the most frequently reported gender is regarded as } \\
\text { representative for the firm founders; when the number of 'females' equals the number of } \\
\text { 'males' we set 'female') }\end{array}$ \\
\hline QUAL & Employees with tertiary-level education yes/no \\
\hline R\&D & R\&D activities yes/no (in previous period) \\
\hline NP & Development and introduction of new products yes/no (in previous period) \\
\hline MP & $\begin{array}{l}\text { Development and introduction of modified existing products yes/no (in previous } \\
\text { period) }\end{array}$ \\
\hline PCOMP & $\begin{array}{l}\text { Intensity of price competition } \\
\text { (transformation of a five-level ordinal variable (level } 1 \text { : 'very weak'; level } 5 \text { : 'very strong') } \\
\text { to a binary variable (value } 1 \text { : levels } 4 \text { and } 5 \text { of the original five-level variable; value } 0 \text { : } \\
\text { levels } 1,2 \text { and } 3 \text { of the original variable) }\end{array}$ \\
\hline NPCOMP & $\begin{array}{l}\text { Intensity of non-price competition } \\
\text { (original and transformed variables as for PCOMP) }\end{array}$ \\
\hline LCAP & Volume of seed capital; natural logarithm \\
\hline AG & $\begin{array}{l}\text { Public limited company } \\
\text { (dummy variable with sole proprietorship as reference legal form) }\end{array}$ \\
\hline $\mathrm{GmbH}$ & $\begin{array}{l}\text { Private limited company } \\
\text { (Dummy variable with sole proprietorship as reference legal form) }\end{array}$ \\
\hline OTHER & $\begin{array}{l}\text { Other legal forms (for example general partnership) } \\
\text { (dummy variable with sole proprietorship as reference legal form) }\end{array}$ \\
\hline LSIZE & Number of employees; natural logarithm \\
\hline IND & $\begin{array}{l}\text { Dummies for three industries } \\
\text { (construction (IND_1); modern services (IND_2); traditional services (IND_3); reference } \\
\text { industry: manufacturing) }\end{array}$ \\
\hline DEBT_CONST & $\begin{array}{l}\text { Importance of debt constraints in the preceding three years } \\
\text { (sum of standardized values (average } 0 \text {, standard deviation 1) of three ordinal variables: } \\
\text { 1) unfavorable credit conditions, 2) credit line too low, 3) insufficient information about } \\
\text { debt financing options) }\end{array}$ \\
\hline CRED_COND & $\begin{array}{l}\text { Importance of unfavorable credit conditions in the preceding three years } \\
\text { (five-level ordinal variable, ranging from "very high" (value 5) to "very low" (value 1)) }\end{array}$ \\
\hline CRED_LINE & $\begin{array}{l}\text { Importance of a too low credit line in the preceding three years } \\
\text { (original variable as for CRED_COND) }\end{array}$ \\
\hline DEBT_INFO & $\begin{array}{l}\text { Importance of insufficient information about debt financing options in the } \\
\text { preceding three years } \\
\text { (original variable as for CRED_COND) }\end{array}$ \\
\hline VC_CONST & $\begin{array}{l}\text { Importance of venture capital constraints in the preceding three years } \\
\text { (original variable as for CRED COND) }\end{array}$ \\
\hline REG & $\begin{array}{l}\text { Dummies for six regions } \\
\text { (Lac Léman (REG_1); Espace Midland (REG_2); North-western Switzerland (REG_3); } \\
\text { Zurich (REG_4); Eastern Switzerland (REG_5); Central Switzerland (REG_6); reference } \\
\text { region: Ticino) }\end{array}$ \\
\hline BUS_PLAN & Firm started with a business plan yes/no \\
\hline UNI & Firm was founded to realize ideas from research at university yes/no \\
\hline T_MARK_SHARE & $\begin{array}{l}\text { Firm targets a high market share } \\
\text { (five-level ordinal variable, ranging from "very high importance" (value 5) to "very low } \\
\text { importance" (value 1)) }\end{array}$ \\
\hline T_NEW_TECH & $\begin{array}{l}\text { Firm targets the application of new technologies } \\
\text { (original variable as for T_MARK_SHARE) }\end{array}$ \\
\hline T_NEW_PROD & $\begin{array}{l}\text { Firm targets the development and introduction of new innovative } \\
\text { products/services } \\
\text { (original variable as for T_MARK_SHARE) }\end{array}$ \\
\hline T_EXPORT & $\begin{array}{l}\text { Firm targets to export products } \\
\text { (original variable as for T MARK SHARE) }\end{array}$ \\
\hline T_RENTAB & Firm targets a high productivity \\
\hline
\end{tabular}


WEALTH_SHARE

SHORT

SUPRA_REG

ST_CREATIVITY

SUP CONS AGENCY

INSAMPLE

DEBT_CONST_INSAMP03

DEBT_CONST_OUTSAMP03

DEBT_CONST_INSAMP06

DEBT_CONST_OUTSAMP06 (original variable as for T MARK SHARE)

Share of founders with private assets at time of firm foundation

Shortage of high-qualified personnel yes/no

(the variable is based on the two ordinal variables 'high-qualified personnel is too

expensive' and 'high-qualified personnel is too difficult to find'; we calculated the average of the scores for these two variables; then transformed the mean of these two five-level ordinal variables (level1: 'very weak'; level 5: 'very strong') to a binary variable (1: values higher than 3 of the mean variable;0: values 3 and lower than 3))

Firm operates supra-regional yes/no

Importance of creativity of firm founders

(five-level ordinal variable, ranging from "very high" (value 5) to "very low" (value 1))

A consulting agency supported firm at time of foundation yes/no

Firm is still in the sample in the following cross-section yes/no

Debt constraints interaction term

(takes value of DEBT_CONST if firm is still in the sample in cross-section 2003, else its value is 0 )

Debt constraints interaction term

(takes value of DEBT_CONST if firm is not in the sample in cross-section 2003, else its value is 0 )

Debt constraints interaction term

(takes value of DEBT_CONST if firm is still in the sample in cross-section 2006, else its value is 0 )

Debt constraints interaction term

(takes value of DEBT_CONST if firm is not in the sample in cross-section 2006, else its value is 0 ) 
Table 4: Multinomial probit estimations used to compute the inverse probability weights [reference: $P\left(S U R V I V A L_{i t} \cap N O A N S W E R_{i t}\right)$ ]

\begin{tabular}{|c|c|c|c|c|c|c|}
\hline Period & \multicolumn{2}{|c|}{2000} & \multicolumn{2}{|c|}{2003} & \multicolumn{2}{|c|}{2006} \\
\hline $\begin{array}{l}\text { Explanatory } \\
\text { variables }\end{array}$ & $\begin{array}{l}\text { NON- } \\
\text { SURVIVAL }\end{array}$ & ANSWER & $\begin{array}{l}\text { NON- } \\
\text { SURVIVAL }\end{array}$ & ANSWER & $\begin{array}{l}\text { NON- } \\
\text { SURVIVAL }\end{array}$ & ANSWER \\
\hline CONSTANT & $\begin{array}{l}0.656^{\star * *} \\
(0.144)\end{array}$ & $\begin{array}{l}-0.520^{* * *} \\
(0.167)\end{array}$ & $\begin{array}{l}0.733^{*} \\
(0.394)\end{array}$ & $\begin{array}{l}1.275^{\star * *} \\
(0.355)\end{array}$ & $\begin{array}{l}-3.027^{*} \\
(1.623)\end{array}$ & $\begin{array}{l}1.079 \\
(1.101)\end{array}$ \\
\hline LAGE & & & & & $\begin{array}{l}0.727^{*} \\
(0.431)\end{array}$ & $\begin{array}{l}-0.076 \\
(0.294)\end{array}$ \\
\hline GENDER & & & $\begin{array}{l}0.050 \\
(0.141)\end{array}$ & $\begin{array}{l}-0.201^{*} \\
(0.121)\end{array}$ & & \\
\hline$R \& D$ & & & $\begin{array}{l}0.288^{\star *} \\
(0.146)\end{array}$ & $\begin{array}{l}0.298^{* *} \\
(0.126)\end{array}$ & & \\
\hline MP & & & $\begin{array}{l}-0.314^{* *} \\
(0.123)\end{array}$ & $\begin{array}{l}-0.178^{*} \\
(0.105)\end{array}$ & & \\
\hline LCAP & & & $\begin{array}{l}-0.064^{* *} \\
(0.031)\end{array}$ & $\begin{array}{l}-0.020 \\
(0.029)\end{array}$ & & \\
\hline$A G$ & & & $\begin{array}{l}-0.051 \\
(0.181)\end{array}$ & $\begin{array}{l}-0.105 \\
(0.158)\end{array}$ & $\begin{array}{l}-0.622^{* *} \\
(0.277)\end{array}$ & $\begin{array}{l}-0.427^{\star *} \\
(0.196)\end{array}$ \\
\hline GMBH & & & $\begin{array}{l}-0.041 \\
(0.140)\end{array}$ & $\begin{array}{l}-0.189 \\
(0.122)\end{array}$ & $\begin{array}{l}-0.416^{*} \\
(0.221)\end{array}$ & $\begin{array}{l}0.108 \\
(0.158)\end{array}$ \\
\hline OTHER & & & $\begin{array}{l}0.180 \\
(0.208)\end{array}$ & $\begin{array}{l}0.322^{*} \\
(0.181)\end{array}$ & $\begin{array}{l}-0.708 \\
(0.436)\end{array}$ & $\begin{array}{l}-0.582^{*} \\
(0.315)\end{array}$ \\
\hline LSIZE & $\begin{array}{l}-0.475^{\star \star \star} \\
(0.058)\end{array}$ & $\begin{array}{l}-0.149 * * \\
(0.060)\end{array}$ & $\begin{array}{l}-0.221^{*} \\
(0.115)\end{array}$ & $\begin{array}{l}-0.134 \\
(0.097)\end{array}$ & $\begin{array}{l}-0.521^{* * *} \\
(0.197)\end{array}$ & $\begin{array}{l}0.041 \\
(0.113)\end{array}$ \\
\hline IND_1 & $\begin{array}{l}0.182 \\
(0.115)\end{array}$ & $\begin{array}{l}0.138 \\
(0.124)\end{array}$ & $\begin{array}{l}-0.360 \\
(0.269)\end{array}$ & $\begin{array}{l}-0.246 \\
(0.229)\end{array}$ & $\begin{array}{l}0.760^{*} \\
(0.450)\end{array}$ & $\begin{array}{l}0.203 \\
(0.313)\end{array}$ \\
\hline IND_2 & $\begin{array}{l}0.186^{\star \star} \\
(0.088)\end{array}$ & $\begin{array}{l}0.248^{\star \star \star} \\
(0.095)\end{array}$ & $\begin{array}{l}0.155 \\
(0.206)\end{array}$ & $\begin{array}{l}0.172 \\
(0.178)\end{array}$ & $\begin{array}{l}0.516 \\
(0.373)\end{array}$ & $\begin{array}{l}0.368 \\
(0.234)\end{array}$ \\
\hline IND_3 & $\begin{array}{l}0.406^{\star * *} \\
(0.085)\end{array}$ & $\begin{array}{l}-0.002 \\
(0.094)\end{array}$ & $\begin{array}{l}-0.165 \\
(0.206)\end{array}$ & $\begin{array}{l}-0.127 \\
(0.179)\end{array}$ & $\begin{array}{l}0.444 \\
(0.365)\end{array}$ & $\begin{array}{l}-0.226 \\
(0.232)\end{array}$ \\
\hline REG_1 & $\begin{array}{l}0.129 \\
(0.122)\end{array}$ & $\begin{array}{l}0.150 \\
(0.148)\end{array}$ & & & & \\
\hline REG_2 & $\begin{array}{l}0.163 \\
(0.121)\end{array}$ & $\begin{array}{l}0.626^{\star * *} \\
(0.146)\end{array}$ & & & & \\
\hline REG_3 & $\begin{array}{l}0.222^{*} \\
(0.124)\end{array}$ & $\begin{array}{l}0.593^{* * *} \\
(0.148)\end{array}$ & & & & \\
\hline REG_4 & \begin{tabular}{|l}
0.142 \\
$(0.119)$
\end{tabular} & $\begin{array}{l}0.628^{* * *} \\
(0.143)\end{array}$ & & & & \\
\hline REG_5 & $\begin{array}{l}0.241^{*} \\
(0.126)\end{array}$ & $\begin{array}{l}0.706^{\star * *} \\
(0.150)\end{array}$ & & & & \\
\hline REG_6 & \begin{tabular}{|l}
0.210 \\
$(0.128)$
\end{tabular} & $\begin{array}{l}0.591^{* * *} \\
(0.152)\end{array}$ & & & & \\
\hline $\begin{array}{l}\mathrm{N} \\
\text { Wald chi }\end{array}$ & & $\begin{array}{l}12 \\
31^{\star \star \star}\end{array}$ & & $\begin{array}{l}25 \\
9^{* * *}\end{array}$ & 58.8 & $\begin{array}{l}5 \\
6^{* * *}\end{array}$ \\
\hline
\end{tabular}

Notes: see table 3 for the variable definitions; heteroskedasticity-robust standard errors (White procedure) are in brackets under the coefficients; ***,**,* denotes statistical significance at the $1 \%, 5 \%$ and $10 \%$ test level, respectively. To increase the model quality we excluded insignificant variables. As usual in empirical literature, we control in each model for sector affiliation. 
Table 5: Testing DEBT_CONST for endogeneity (Rivers-Vuong-Test)

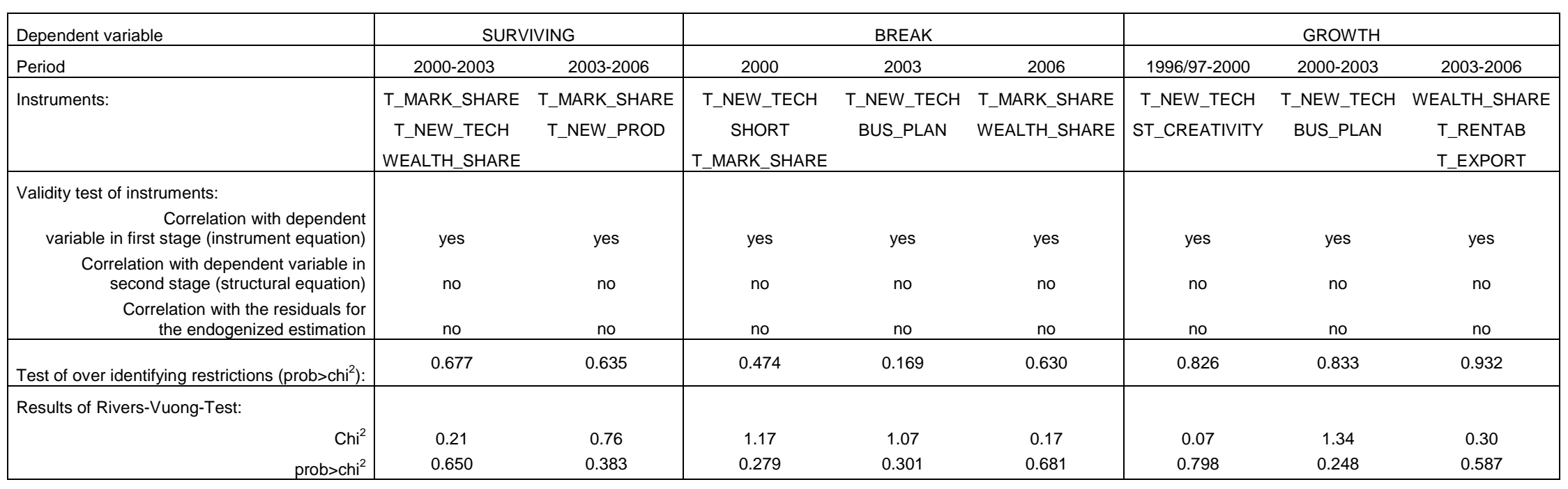


Table 6: Testing VC_CONST for endogeneity (Rivers-Vuong-Test)

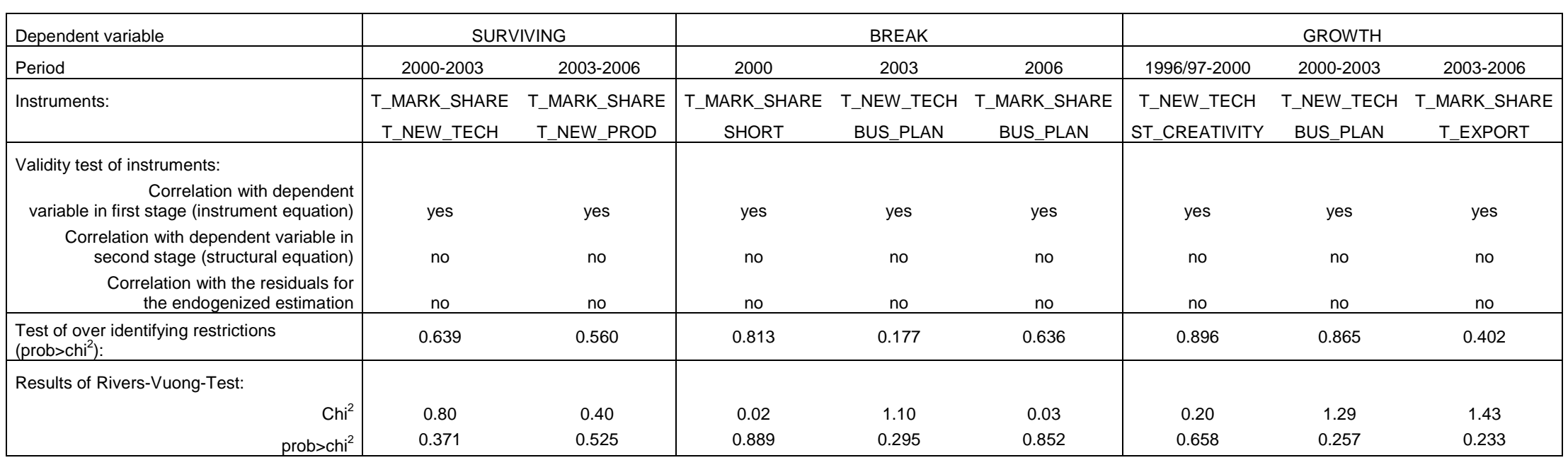


Table 7: Survival of start-ups; probit estimates

\begin{tabular}{|c|c|c|c|c|c|c|c|c|c|c|}
\hline \multirow{2}{*}{$\begin{array}{l}\text { Period } \\
\text { Explanatory variables }\end{array}$} & \multicolumn{5}{|c|}{ SURVIVING 2000-2003 } & \multicolumn{5}{|c|}{ SURVIVING 2003-2006 } \\
\hline & (1) & (2) & (3) & (4) & (5) & (1) & (2) & (3) & (4) & (5) \\
\hline CONSTANT & $\begin{array}{l}-0.103 \\
(0.692)\end{array}$ & $\begin{array}{l}-0.003 \\
(0.699)\end{array}$ & $\begin{array}{l}-0.098 \\
(0.695)\end{array}$ & $\begin{array}{l}-0.068 \\
(0.696)\end{array}$ & $\begin{array}{l}-0.217 \\
(0.691)\end{array}$ & $\begin{array}{l}3.720^{* * *} \\
(1.161)\end{array}$ & $\begin{array}{c}3.770^{* * *} \\
(1.163)\end{array}$ & $\begin{array}{c}3.789^{* * *} \\
(1.167)\end{array}$ & $\begin{array}{c}3.965^{* * *} \\
(1.150)\end{array}$ & $\begin{array}{l}3.803^{* * *} \\
(1.161)\end{array}$ \\
\hline MAIN & $\begin{array}{l}0.251^{* * *} \\
(0.097)\end{array}$ & $\begin{array}{l}0.250^{* *} \\
(0.097)\end{array}$ & $\begin{array}{c}0.251^{* * *} \\
(0.097)\end{array}$ & $\begin{array}{l}0.247^{* *} \\
(0.097)\end{array}$ & $\begin{array}{l}0.241^{* *} \\
(0.097)\end{array}$ & $\begin{array}{l}-0.019 \\
(0.165)\end{array}$ & $\begin{array}{l}-0.015 \\
(0.166)\end{array}$ & $\begin{array}{l}-0.016 \\
(0.165)\end{array}$ & $\begin{array}{l}-0.034 \\
(0.164)\end{array}$ & $\begin{array}{l}-0.017 \\
(0.166)\end{array}$ \\
\hline UNEMPLOY & $\begin{array}{l}0.143 \\
(0.116)\end{array}$ & $\begin{array}{c}0.137 \\
(0.117)\end{array}$ & $\begin{array}{c}0.141 \\
(0.116)\end{array}$ & $\begin{array}{c}0.140 \\
(0.116)\end{array}$ & $\begin{array}{c}0.133 \\
(0.117)\end{array}$ & $\begin{array}{c}0.003 \\
(0.167)\end{array}$ & $\begin{array}{l}-0.001 \\
(0.167)\end{array}$ & $\begin{array}{l}-0.001 \\
(0.167)\end{array}$ & $\begin{array}{c}0.008 \\
(0.166)\end{array}$ & $\begin{array}{c}0.001 \\
(0.166)\end{array}$ \\
\hline LAGE & $\begin{array}{c}0.109 \\
(0.180)\end{array}$ & $\begin{array}{c}0.113 \\
(0.181)\end{array}$ & $\begin{array}{c}0.130 \\
(0.180)\end{array}$ & $\begin{array}{c}0.126 \\
(0.180)\end{array}$ & $\begin{array}{c}0.155 \\
(0.180)\end{array}$ & $\begin{array}{l}-0.717^{* *} \\
(0.305)\end{array}$ & $\begin{array}{l}-0.717^{\star \star} \\
(0.306)\end{array}$ & $\begin{array}{c}-0.719^{* *} \\
(0.306)\end{array}$ & $\begin{array}{c}-0.734^{* *} \\
(0.303)\end{array}$ & $\begin{array}{l}-0.725^{\star \star} \\
(0.307)\end{array}$ \\
\hline GENDER & $\begin{array}{l}-0.121 \\
(0.093)\end{array}$ & $\begin{array}{l}-0.122 \\
(0.093)\end{array}$ & $\begin{array}{l}-0.120 \\
(0.093)\end{array}$ & $\begin{array}{l}-0.126 \\
(0.093)\end{array}$ & $\begin{array}{l}-0.128 \\
(0.093)\end{array}$ & $\begin{array}{c}0.012 \\
(0.149)\end{array}$ & $\begin{array}{c}0.011 \\
(0.149)\end{array}$ & $\begin{array}{c}0.011 \\
(0.149)\end{array}$ & $\begin{array}{c}0.017 \\
(0.150)\end{array}$ & $\begin{array}{c}0.012 \\
(0.150)\end{array}$ \\
\hline QUAL & $\begin{array}{l}-0.024 \\
(0.083)\end{array}$ & $\begin{array}{l}-0.021 \\
(0.083)\end{array}$ & $\begin{array}{l}-0.021 \\
(0.083)\end{array}$ & $\begin{array}{l}-0.021 \\
(0.083)\end{array}$ & $\begin{array}{l}-0.009 \\
(0.083)\end{array}$ & $\begin{array}{c}0.092 \\
(0.139)\end{array}$ & $\begin{array}{l}0.096 \\
(0.138)\end{array}$ & $\begin{array}{c}0.094 \\
(0.139)\end{array}$ & $\begin{array}{c}0.097 \\
(0.138)\end{array}$ & $\begin{array}{c}0.101 \\
(0.138)\end{array}$ \\
\hline$R \& D$ & $\begin{array}{l}-0.045 \\
(0.100)\end{array}$ & $\begin{array}{l}-0.052 \\
(0.100)\end{array}$ & $\begin{array}{l}-0.049 \\
(0.100)\end{array}$ & $\begin{array}{l}-0.047 \\
(0.100)\end{array}$ & $\begin{array}{l}-0.051 \\
(0.101)\end{array}$ & $\begin{array}{l}-0.047 \\
(0.171)\end{array}$ & $\begin{array}{l}-0.054 \\
(0.170)\end{array}$ & & 3) & \\
\hline NP & $\begin{array}{l}-0.057 \\
(0.108)\end{array}$ & $\begin{array}{l}-0.054 \\
(0.108)\end{array}$ & $\begin{array}{l}-0.062 \\
(0.108)\end{array}$ & $\begin{array}{l}-0.064 \\
(0.108)\end{array}$ & $\begin{array}{l}-0.070 \\
(0.108)\end{array}$ & $\begin{array}{l}-0.048 \\
(0.198)\end{array}$ & $\begin{array}{l}-0.051 \\
(0.198)\end{array}$ & $\begin{array}{l}-0 \\
(0 .\end{array}$ & 8) & $\begin{array}{l}-0 . \\
(0.1\end{array}$ \\
\hline MP & $\begin{array}{l}0.158^{*} \\
(0.084)\end{array}$ & $\begin{array}{l}0.157^{\star} \\
(0.084)\end{array}$ & $\begin{array}{l}0.155^{\star} \\
(0.084)\end{array}$ & $\begin{array}{l}0.156^{*} \\
(0.084)\end{array}$ & $\begin{array}{l}0.152^{*} \\
(0.084)\end{array}$ & $\begin{array}{c}0.044 \\
(0.133)\end{array}$ & $\begin{array}{c}0.038 \\
(0.132)\end{array}$ & $\begin{array}{c}0.042 \\
(0.132)\end{array}$ & $\begin{array}{l}0.0 \\
(0.1\end{array}$ & $\begin{array}{c}0.038 \\
(0.133)\end{array}$ \\
\hline PCOMP & $\begin{array}{l}-0.056 \\
(0.076)\end{array}$ & $\begin{array}{l}-0.055 \\
(0.076)\end{array}$ & $\begin{array}{l}-0.059 \\
(0.076)\end{array}$ & $\begin{array}{l}-0.063 \\
(0.076)\end{array}$ & $\begin{array}{l}-0.065 \\
(0.076)\end{array}$ & $\begin{array}{l}-0.097 \\
(0.120)\end{array}$ & $\begin{array}{l}-0.105 \\
(0.120)\end{array}$ & & $\begin{array}{l}-0.094 \\
(0.119)\end{array}$ & \\
\hline NPCOMP & $\begin{array}{l}-0.050 \\
(0.077)\end{array}$ & $\begin{array}{l}-0.050 \\
(0.077)\end{array}$ & $\begin{array}{l}-0.052 \\
(0.077)\end{array}$ & $\begin{array}{l}-0.048 \\
(0.077)\end{array}$ & $\begin{array}{l}-0.051 \\
(0.077)\end{array}$ & $\begin{array}{l}-0.062 \\
(0.121)\end{array}$ & $\begin{array}{l}-0.063 \\
(0.121)\end{array}$ & $\begin{array}{l}-0.064 \\
(0.121)\end{array}$ & $\begin{array}{l}-0.065 \\
(0.122)\end{array}$ & $\begin{array}{l}-0.064 \\
(0.121)\end{array}$ \\
\hline LCAP & $\begin{array}{l}0.039^{* *} \\
(0.018)\end{array}$ & $\begin{array}{l}0.039^{\star *} \\
(0.018)\end{array}$ & $\begin{array}{l}0.040^{* *} \\
(0.018)\end{array}$ & $\begin{array}{l}0.038^{* *} \\
(0.018)\end{array}$ & $\begin{array}{l}0.039^{\star *} \\
(0.018)\end{array}$ & $\begin{array}{l}-0.002 \\
(0.034)\end{array}$ & $\begin{array}{l}-0.003 \\
(0.034)\end{array}$ & $\begin{array}{l}-0.003 \\
(0.034)\end{array}$ & $\begin{array}{l}-0.002 \\
(0.034)\end{array}$ & $\begin{array}{l}-0.003 \\
(0.034)\end{array}$ \\
\hline AG & $\begin{array}{c}0.078 \\
(0.123)\end{array}$ & $\begin{array}{c}0.079 \\
(0.123)\end{array}$ & $\begin{array}{c}0.075 \\
(0.123)\end{array}$ & $\begin{array}{c}0.072 \\
(0.123)\end{array}$ & $\begin{array}{c}0.071 \\
(0.123)\end{array}$ & $\begin{array}{c}0.234 \\
(0.194)\end{array}$ & $\begin{array}{c}0.234 \\
(0.195)\end{array}$ & & $\begin{array}{l}0.2 \\
(0.1\end{array}$ & $\begin{array}{c}0.234 \\
(0.196)\end{array}$ \\
\hline $\mathrm{GMBH}$ & $\begin{array}{l}-0.003 \\
(0.093)\end{array}$ & $\begin{array}{c}0.000 \\
(0.093)\end{array}$ & $\begin{array}{l}-0.005 \\
(0.093)\end{array}$ & $\begin{array}{l}-0.009 \\
(0.093)\end{array}$ & $\begin{array}{l}-0.010 \\
(0.093)\end{array}$ & $\begin{array}{l}0.402^{* *} \\
(0.161)\end{array}$ & $\begin{array}{l}0.399^{* *} \\
(0.160)\end{array}$ & $\begin{array}{l}0.398^{* *} \\
(0.159)\end{array}$ & $\begin{array}{l}0.416^{* *} \\
(0.163)\end{array}$ & $\begin{array}{l}0.400^{* *} \\
(0.160)\end{array}$ \\
\hline $\mathrm{OTH}$ & $\begin{array}{c}0.061 \\
(0.133)\end{array}$ & $\begin{array}{c}0.058 \\
(0.133)\end{array}$ & $\begin{array}{c}0.061 \\
(0.133)\end{array}$ & $\begin{array}{c}0.063 \\
(0.133)\end{array}$ & $\begin{array}{c}0.060 \\
(0.132)\end{array}$ & $\begin{array}{c}0.303 \\
(0.318)\end{array}$ & $\begin{array}{c}0.307 \\
(0.319)\end{array}$ & $\begin{array}{l}0.3 \\
(0.3\end{array}$ & $\begin{array}{l}0.3 \\
(0.3\end{array}$ & $\begin{array}{l}0.3 \\
(0.3\end{array}$ \\
\hline LSIZE & $\begin{array}{c}0.069 \\
(0.080)\end{array}$ & $\begin{array}{c}0.068 \\
(0.080)\end{array}$ & $\begin{array}{c}0.072 \\
(0.080)\end{array}$ & $\begin{array}{c}0.064 \\
(0.080)\end{array}$ & $\begin{array}{c}0.065 \\
(0.080)\end{array}$ & $\begin{array}{c}0.444^{\star \star *} \\
(0.153)\end{array}$ & $\begin{array}{c}0.442^{\star * \star} \\
(0.152)\end{array}$ & $\begin{array}{c}0.441^{\star \star \star} \\
(0.152)\end{array}$ & $\begin{array}{c}0.436^{\star \star *} \\
(0.157)\end{array}$ & $\begin{array}{c}0.438^{\star * \star} \\
(0.154)\end{array}$ \\
\hline IND_1 & $\begin{array}{c}0.164 \\
(0.181)\end{array}$ & $\begin{array}{c}0.160 \\
(0.181)\end{array}$ & $\begin{array}{c}0.162 \\
(0.181)\end{array}$ & $\begin{array}{c}0.163 \\
(0.181)\end{array}$ & $\begin{array}{c}0.164 \\
(0.181)\end{array}$ & $\begin{array}{l}-0.444 \\
(0.313)\end{array}$ & $\begin{array}{l}-0.441 \\
(0.315)\end{array}$ & $\begin{array}{l}-0.445 \\
(0.314)\end{array}$ & $\begin{array}{l}-0.486 \\
(0.313)\end{array}$ & $\begin{array}{l}-0.448 \\
(0.314)\end{array}$ \\
\hline IND_2 & $\begin{array}{l}-0.040 \\
(0.139)\end{array}$ & $\begin{array}{l}-0.046 \\
(0.139)\end{array}$ & $\begin{array}{l}-0.040 \\
(0.139)\end{array}$ & $\begin{array}{l}-0.028 \\
(0.138)\end{array}$ & $\begin{array}{l}-0.024 \\
(0.138)\end{array}$ & $\begin{array}{l}-0.192 \\
(0.267)\end{array}$ & $\begin{array}{l}-0.182 \\
(0.269)\end{array}$ & $\begin{array}{l}-0.185 \\
(0.268)\end{array}$ & $\begin{array}{l}-0.225 \\
(0.266)\end{array}$ & $\begin{array}{l}-0.186 \\
(0.269)\end{array}$ \\
\hline IND_3 & $\begin{array}{c}0.122 \\
(0.138)\end{array}$ & $\begin{array}{c}0.118 \\
(0.138)\end{array}$ & $\begin{array}{c}0.116 \\
(0.138)\end{array}$ & $\begin{array}{c}0.124 \\
(0.139)\end{array}$ & $\begin{array}{c}0.121 \\
(0.139)\end{array}$ & $\begin{array}{l}-0.455^{\star} \\
(0.261)\end{array}$ & $\begin{array}{l}-0.456^{*} \\
(0.264)\end{array}$ & $\begin{array}{l}-0.462^{*} \\
(0.262)\end{array}$ & $\begin{array}{l}-0.479^{*} \\
(0.259)\end{array}$ & $\begin{array}{l}-0.465^{*} \\
(0.262)\end{array}$ \\
\hline DEBT_CONST & $\begin{array}{c}-0.030^{\star *} \\
(0.015)\end{array}$ & & & & & $\begin{array}{l}-0.024 \\
(0.024)\end{array}$ & & & & \\
\hline CRED_COND & & $\begin{array}{c}-0.054^{* *} \\
(0.025)\end{array}$ & & & & & $\begin{array}{l}-0.020 \\
(0.045)\end{array}$ & & & \\
\hline CRED_ & & & $\begin{array}{l}-0.043^{*} \\
(0.025)\end{array}$ & & & & & $\begin{array}{l}-0.021 \\
(0.047)\end{array}$ & & \\
\hline DEBT_INFO & & & & $\begin{array}{l}-0.045 \\
(0.029)\end{array}$ & & & & & $\begin{array}{l}-0.086 \\
(0.053)\end{array}$ & \\
\hline VC_CONST & & & & & $\begin{array}{l}-0.023 \\
(0.033) \\
\end{array}$ & & & & & $\begin{array}{l}-0.017 \\
(0.053) \\
\end{array}$ \\
\hline $\mathrm{N}$ & 1589 & 1589 & 1589 & 1589 & 1589 & 911 & 911 & 911 & 911 & 911 \\
\hline Pseudo $\mathrm{R}^{2}$ & 0.023 & 0.023 & 0.022 & 0.022 & 0.020 & 0.075 & 0.074 & 0.074 & 0.078 & 0.073 \\
\hline Wald chi ${ }^{2}$ & $32.98^{\star *}$ & $33.21^{* *}$ & $32.17^{\star \star}$ & $31.48^{\star *}$ & $29.83^{*}$ & $41.24^{\star \star \star}$ & $40.07^{\star \star *}$ & $40.15^{\star \star \star}$ & $41.22^{\star \star \star}$ & $39.39^{\star \star \star}$ \\
\hline
\end{tabular}

Notes: see table 3 for the variable definitions; heteroskedasticity-robust standard errors (White procedure) are in brackets under the coefficients; ***,**,* denotes statistical significance at the $1 \%, 5 \%$ and $10 \%$ test level, respectively. 
Table 8: Profit break-even of start-ups; weighted probit estimates

\begin{tabular}{|c|c|c|c|c|c|c|c|c|c|c|c|c|c|c|c|}
\hline \multirow{2}{*}{\begin{tabular}{|l} 
Period \\
Explanatory \\
variables
\end{tabular}} & \multicolumn{5}{|c|}{ BREAK 2000} & \multicolumn{5}{|c|}{ BREAK 2003} & \multicolumn{5}{|c|}{ BREAK 2006} \\
\hline & (1) & (2) & (3) & (4) & (5) & (1) & (2) & (3) & (4) & (5) & (1) & (2) & (3) & (4) & (5) \\
\hline CONSTANT & $\begin{array}{c}0.379 \\
(0.627)\end{array}$ & $\begin{array}{c}0.528 \\
(0.634)\end{array}$ & $\begin{array}{c}0.453 \\
(0.630)\end{array}$ & $\begin{array}{c}0.418 \\
(0.634)\end{array}$ & $\begin{array}{c}0.242 \\
(0.629)\end{array}$ & $\begin{array}{c}0.019 \\
(0.885)\end{array}$ & $\begin{array}{c}0.161 \\
(0.886)\end{array}$ & $\begin{array}{c}0.203 \\
(0.886)\end{array}$ & $\begin{array}{c}0.257 \\
(0.881)\end{array}$ & $\begin{array}{c}0.195 \\
(0.891)\end{array}$ & $\begin{array}{c}3.156^{* * *} \\
(1.221)\end{array}$ & $\begin{array}{c}3.280^{* * *} \\
(1.232)\end{array}$ & $\begin{array}{c}3.318^{* * *} \\
(1.234)\end{array}$ & $\begin{array}{c}3.315^{\star \star \star} \\
(1.212)\end{array}$ & $\begin{array}{l}2.908^{\star *} \\
(1.188)\end{array}$ \\
\hline MAIN & $\begin{array}{c}0.350^{\star \star *} \\
(0.092)\end{array}$ & $\begin{array}{c}0.344^{\star \star *} \\
(0.092)\end{array}$ & $\begin{array}{c}0.354^{* \star *} \\
(0.092)\end{array}$ & $\begin{array}{c}0.339^{\star \star \star} \\
(0.092)\end{array}$ & $\begin{array}{c}0.327^{\star * *} \\
(0.092)\end{array}$ & $\begin{array}{l}0.281^{\star \star} \\
(0.135)\end{array}$ & $\begin{array}{l}0.293^{\star *} \\
(0.135)\end{array}$ & $\begin{array}{l}0.281^{* *} \\
(0.135)\end{array}$ & $\begin{array}{l}0.270^{\star *} \\
(0.134)\end{array}$ & $\begin{array}{l}0.268^{\star *} \\
(0.134)\end{array}$ & $\begin{array}{l}-0.151 \\
(0.202)\end{array}$ & $\begin{array}{l}-0.141 \\
(0.202)\end{array}$ & $\begin{array}{c}-0.168 \\
(0.201)\end{array}$ & $\begin{array}{l}-0.163 \\
(0.200)\end{array}$ & $\begin{array}{l}-0.197 \\
(0.202)\end{array}$ \\
\hline UNEMPLOY & $\begin{array}{l}-0.112 \\
(0.107)\end{array}$ & $\begin{array}{l}-0.128 \\
(0.106)\end{array}$ & $\begin{array}{l}-0.113 \\
(0.106)\end{array}$ & $\begin{array}{l}-0.119 \\
(0.106)\end{array}$ & $\begin{array}{l}-0.115 \\
(0.106)\end{array}$ & $\begin{array}{l}-0.098 \\
(0.145)\end{array}$ & $\begin{array}{l}-0.105 \\
(0.143)\end{array}$ & $\begin{array}{l}-0.101 \\
(0.144)\end{array}$ & $\begin{array}{l}-0.110 \\
(0.147)\end{array}$ & $\begin{array}{l}-0.100 \\
(0.143)\end{array}$ & $\begin{array}{l}-0.030 \\
(0.194)\end{array}$ & $\begin{array}{l}-0.036 \\
(0.194)\end{array}$ & $\begin{array}{l}-0.046 \\
(0.192)\end{array}$ & $\begin{array}{l}-0.062 \\
(0.191)\end{array}$ & $\begin{array}{l}-0.117 \\
(0.186)\end{array}$ \\
\hline LAGE & $\begin{array}{l}-0.011 \\
(0.167)\end{array}$ & $\begin{array}{c}0.008 \\
(0.166)\end{array}$ & $\begin{array}{c}0.019 \\
(0.166)\end{array}$ & $\begin{array}{c}0.031 \\
(0.166)\end{array}$ & $\begin{array}{c}0.067 \\
(0.166)\end{array}$ & $\begin{array}{c}0.088 \\
(0.231)\end{array}$ & $\begin{array}{c}0.085 \\
(0.231)\end{array}$ & $\begin{array}{c}0.091 \\
(0.231)\end{array}$ & $\begin{array}{c}0.093 \\
(0.231)\end{array}$ & $\begin{array}{c}0.088 \\
(0.233)\end{array}$ & $\begin{array}{l}-0.636^{\star} \\
(0.325)\end{array}$ & $\begin{array}{l}-0.599^{*} \\
(0.323)\end{array}$ & $\begin{array}{l}-0.613^{*} \\
(0.323)\end{array}$ & $\begin{array}{l}-0.604^{*} \\
(0.317)\end{array}$ & $\begin{array}{l}-0.541^{*} \\
(0.312)\end{array}$ \\
\hline GENDER & $\begin{array}{c}0.046 \\
(0.085)\end{array}$ & $\begin{array}{c}0.044 \\
(0.085)\end{array}$ & $\begin{array}{c}0.050 \\
(0.085)\end{array}$ & $\begin{array}{c}0.035 \\
(0.085)\end{array}$ & $\begin{array}{c}0.028 \\
(0.085)\end{array}$ & $\begin{array}{c}0.167 \\
(0.119)\end{array}$ & $\begin{array}{c}0.162 \\
(0.119)\end{array}$ & $\begin{array}{c}0.163 \\
(0.119)\end{array}$ & $\begin{array}{c}0.166 \\
(0.119)\end{array}$ & $\begin{array}{c}0.168 \\
(0.118)\end{array}$ & $\begin{array}{c}0.150 \\
(0.153)\end{array}$ & $\begin{array}{c}0.139 \\
(0.151)\end{array}$ & $\begin{array}{c}0.143 \\
(0.151)\end{array}$ & $\begin{array}{c}0.149 \\
(0.153)\end{array}$ & $\begin{array}{c}0.119 \\
(0.152)\end{array}$ \\
\hline QUAL & $\begin{array}{c}0.089 \\
(0.080)\end{array}$ & $\begin{array}{c}0.096 \\
(0.079)\end{array}$ & $\begin{array}{c}0.089 \\
(0.079)\end{array}$ & $\begin{array}{c}0.096 \\
(0.079)\end{array}$ & $\begin{array}{c}0.120 \\
(0.079)\end{array}$ & $\begin{array}{c}0.130 \\
(0.113)\end{array}$ & $\begin{array}{c}0.140 \\
(0.113)\end{array}$ & $\begin{array}{c}0.127 \\
(0.113)\end{array}$ & $\begin{array}{c}0.139 \\
(0.113)\end{array}$ & $\begin{array}{c}0.156 \\
(0.113)\end{array}$ & $\begin{array}{c}0.034 \\
(0.143)\end{array}$ & $\begin{array}{c}0.023 \\
(0.144)\end{array}$ & $\begin{array}{c}0.019 \\
(0.143)\end{array}$ & $\begin{array}{c}0.064 \\
(0.143)\end{array}$ & $\begin{array}{c}0.050 \\
(0.142)\end{array}$ \\
\hline$R \& D$ & $\begin{array}{l}-0.072 \\
(0.095)\end{array}$ & $\begin{array}{l}-0.089 \\
(0.095)\end{array}$ & $\begin{array}{l}-0.076 \\
(0.095)\end{array}$ & $\begin{array}{l}-0.080 \\
(0.095)\end{array}$ & $\begin{array}{l}-0.064 \\
(0.097)\end{array}$ & $\begin{array}{c}-0.293^{\star *} \\
(0.131)\end{array}$ & $\begin{array}{c}-0.300^{* *} \\
(0.132)\end{array}$ & $\begin{array}{c}-0.313^{\star \star} \\
(0.132)\end{array}$ & $\begin{array}{c}-0.284^{* *} \\
(0.131)\end{array}$ & $\begin{array}{c}-0.301^{* *} \\
(0.131)\end{array}$ & $\begin{array}{l}-0.352^{\star} \\
(0.189)\end{array}$ & $\begin{array}{c}-0.379^{\star *} \\
(0.189)\end{array}$ & $\begin{array}{l}-0.359^{*} \\
(0.189)\end{array}$ & $\begin{array}{l}-0.358^{\star} \\
(0.189)\end{array}$ & $\begin{array}{c}-0.390^{* *} \\
(0.187)\end{array}$ \\
\hline NP & $\begin{array}{l}-0.106 \\
(0.101)\end{array}$ & $\begin{array}{l}-0.108 \\
(0.101)\end{array}$ & $\begin{array}{l}-0.111 \\
(0.101)\end{array}$ & $\begin{array}{l}-0.121 \\
(0.100)\end{array}$ & $\begin{array}{c}-0.122 \\
(0.101)\end{array}$ & $\begin{array}{c}0.481^{* * *} \\
(0.175)\end{array}$ & $\begin{array}{c}0.477^{\star * *} \\
(0.175)\end{array}$ & $\begin{array}{c}0.486^{* \star *} \\
(0.175)\end{array}$ & $\begin{array}{c}0.473^{\star \star *} \\
(0.175)\end{array}$ & $\begin{array}{c}0.479^{\star \star *} \\
(0.174)\end{array}$ & $\begin{array}{c}0.015 \\
(0.209)\end{array}$ & $\begin{array}{l}-0.005 \\
(0.209)\end{array}$ & $\begin{array}{c}-0.018 \\
(0.202)\end{array}$ & $\begin{array}{c}0.017 \\
(0.210)\end{array}$ & $\begin{array}{l}-0.007 \\
(0.206)\end{array}$ \\
\hline MP & $\begin{array}{c}0.092 \\
(0.079)\end{array}$ & $\begin{array}{c}0.086 \\
(0.079)\end{array}$ & $\begin{array}{c}0.091 \\
(0.079)\end{array}$ & $\begin{array}{c}0.087 \\
(0.078)\end{array}$ & $\begin{array}{c}0.082 \\
(0.079)\end{array}$ & $\begin{array}{c}0.156 \\
(0.107)\end{array}$ & $\begin{array}{c}0.147 \\
(0.106)\end{array}$ & $\begin{array}{c}0.158 \\
(0.107)\end{array}$ & $\begin{array}{c}0.152 \\
(0.107)\end{array}$ & $\begin{array}{c}0.151 \\
(0.107)\end{array}$ & $\begin{array}{l}-0.025 \\
(0.137)\end{array}$ & $\begin{array}{l}-0.022 \\
(0.137)\end{array}$ & $\begin{array}{c}-0.037 \\
(0.137)\end{array}$ & $\begin{array}{l}-0.031 \\
(0.135)\end{array}$ & $\begin{array}{l}-0.031 \\
(0.135)\end{array}$ \\
\hline PCOMP & $\begin{array}{l}-0.022 \\
(0.072)\end{array}$ & $\begin{array}{l}-0.024 \\
(0.072)\end{array}$ & $\begin{array}{l}-0.020 \\
(0.072)\end{array}$ & $\begin{array}{l}-0.037 \\
(0.072)\end{array}$ & $\begin{array}{l}-0.026 \\
(0.072)\end{array}$ & $\begin{array}{l}-0.020 \\
(0.101)\end{array}$ & $\begin{array}{l}-0.030 \\
(0.100)\end{array}$ & $\begin{array}{l}-0.026 \\
(0.101)\end{array}$ & $\begin{array}{l}-0.026 \\
(0.100)\end{array}$ & $\begin{array}{l}-0.046 \\
(0.099)\end{array}$ & $\begin{array}{l}-0.056 \\
(0.130)\end{array}$ & $\begin{array}{l}-0.014 \\
(0.130)\end{array}$ & $\begin{array}{l}-0.057 \\
(0.130)\end{array}$ & $\begin{array}{l}-0.078 \\
(0.129)\end{array}$ & $\begin{array}{l}-0.039 \\
(0.130)\end{array}$ \\
\hline NPCOMP & $\begin{array}{c}0.052 \\
(0.073)\end{array}$ & $\begin{array}{c}0.055 \\
(0.073)\end{array}$ & $\begin{array}{c}0.046 \\
(0.074)\end{array}$ & $\begin{array}{c}0.058 \\
(0.073)\end{array}$ & $\begin{array}{c}0.051 \\
(0.073)\end{array}$ & $\begin{array}{l}0.219^{\star *} \\
(0.100)\end{array}$ & $\begin{array}{l}0.221^{* *} \\
(0.099)\end{array}$ & $\begin{array}{l}0.222^{* *} \\
(0.099)\end{array}$ & $\begin{array}{l}0.213^{* *} \\
(0.099)\end{array}$ & $\begin{array}{l}0.223^{* *} \\
(0.099)\end{array}$ & $\begin{array}{c}0.522^{\star * *} \\
(0.134)\end{array}$ & $\begin{array}{c}0.506^{\star \star \star} \\
(0.133)\end{array}$ & $\begin{array}{c}0.539^{\star * \star} \\
(0.133)\end{array}$ & $\begin{array}{c}0.503^{\star * *} \\
(0.134)\end{array}$ & $\begin{array}{c}0.497^{\star * *} \\
(0.133)\end{array}$ \\
\hline LCAP & $\begin{array}{l}-0.013 \\
(0.021)\end{array}$ & $\begin{array}{l}-0.012 \\
(0.021)\end{array}$ & $\begin{array}{l}-0.010 \\
(0.021)\end{array}$ & $\begin{array}{l}-0.015 \\
(0.021)\end{array}$ & $\begin{array}{c}-0.012 \\
(0.021)\end{array}$ & $\begin{array}{c}0.009 \\
(0.029)\end{array}$ & $\begin{array}{c}0.011 \\
(0.029)\end{array}$ & $\begin{array}{c}0.008 \\
(0.029)\end{array}$ & $\begin{array}{c}0.006 \\
(0.028)\end{array}$ & $\begin{array}{c}0.008 \\
(0.029)\end{array}$ & $\begin{array}{c}0.001 \\
(0.036)\end{array}$ & $\begin{array}{c}0.004 \\
(0.035)\end{array}$ & $\begin{array}{c}0.006 \\
(0.036)\end{array}$ & $\begin{array}{c}0.002 \\
(0.036)\end{array}$ & $\begin{array}{c}0.012 \\
(0.036)\end{array}$ \\
\hline$A G$ & $\begin{array}{c}0.108 \\
(0.118)\end{array}$ & $\begin{array}{c}0.108 \\
(0.118)\end{array}$ & $\begin{array}{c}0.111 \\
(0.118)\end{array}$ & $\begin{array}{c}0.089 \\
(0.118)\end{array}$ & $\begin{array}{c}0.087 \\
(0.117)\end{array}$ & $\begin{array}{c}-0.413^{* * *} \\
(0.156)\end{array}$ & $\begin{array}{c}-0.403^{\star * *} \\
(0.156)\end{array}$ & $\begin{array}{c}-0.407^{\star * *} \\
(0.156)\end{array}$ & $\begin{array}{c}-0.421^{* * *} \\
(0.155)\end{array}$ & $\begin{array}{c}-0.392^{* *} \\
(0.156)\end{array}$ & $\begin{array}{l}-0.304 \\
(0.215)\end{array}$ & $\begin{array}{l}-0.275 \\
(0.216)\end{array}$ & $\begin{array}{l}-0.317 \\
(0.213)\end{array}$ & $\begin{array}{l}-0.294 \\
(0.212)\end{array}$ & $\begin{array}{l}-0.271 \\
(0.214)\end{array}$ \\
\hline GMBH & $\begin{array}{c}-0.178^{\star *} \\
(0.089)\end{array}$ & $\begin{array}{l}-0.172^{\star} \\
(0.089)\end{array}$ & $\begin{array}{c}-0.181^{* *} \\
(0.089)\end{array}$ & $\begin{array}{c}-0.191^{* *} \\
(0.089)\end{array}$ & $\begin{array}{c}-0.188^{* *} \\
(0.089)\end{array}$ & $\begin{array}{c}-0.283^{* *} \\
(0.118)\end{array}$ & $\begin{array}{c}-0.286^{* *} \\
(0.118)\end{array}$ & $\begin{array}{c}-0.291^{* *} \\
(0.118)\end{array}$ & $\begin{array}{c}-0.277^{* *} \\
(0.119)\end{array}$ & $\begin{array}{c}-0.280^{* *} \\
(0.118)\end{array}$ & $\begin{array}{l}-0.117 \\
(0.159)\end{array}$ & $\begin{array}{l}-0.132 \\
(0.158)\end{array}$ & $\begin{array}{l}-0.142 \\
(0.158)\end{array}$ & $\begin{array}{l}-0.118 \\
(0.160)\end{array}$ & $\begin{array}{l}-0.161 \\
(0.156)\end{array}$ \\
\hline OTHER & $\begin{array}{c}-0.008 \\
(0.127)\end{array}$ & $\begin{array}{c}-0.014 \\
(0.127)\end{array}$ & $\begin{array}{l}-0.006 \\
(0.127)\end{array}$ & $\begin{array}{l}-0.009 \\
(0.127)\end{array}$ & $\begin{array}{c}-0.017 \\
(0.127)\end{array}$ & $\begin{array}{l}-0.137 \\
(0.267)\end{array}$ & $\begin{array}{l}-0.119 \\
(0.267)\end{array}$ & $\begin{array}{l}-0.144 \\
(0.268)\end{array}$ & $\begin{array}{l}-0.122 \\
(0.267)\end{array}$ & $\begin{array}{l}-0.101 \\
(0.268)\end{array}$ & $\begin{array}{c}0.144 \\
(0.362)\end{array}$ & $\begin{array}{c}0.125 \\
(0.358)\end{array}$ & $\begin{array}{c}0.100 \\
(0.353)\end{array}$ & $\begin{array}{c}0.147 \\
(0.356)\end{array}$ & $\begin{array}{c}0.117 \\
(0.332)\end{array}$ \\
\hline LSIZE & $\begin{array}{c}0.149 \\
(0.119)\end{array}$ & $\begin{array}{c}0.134 \\
(0.119)\end{array}$ & $\begin{array}{c}0.149 \\
(0.120)\end{array}$ & $\begin{array}{c}0.144 \\
(0.115)\end{array}$ & $\begin{array}{c}0.140 \\
(0.116)\end{array}$ & $\begin{array}{l}-0.015 \\
(0.101)\end{array}$ & $\begin{array}{l}-0.023 \\
(0.101)\end{array}$ & $\begin{array}{l}-0.015 \\
(0.102)\end{array}$ & $\begin{array}{l}-0.019 \\
(0.101)\end{array}$ & $\begin{array}{l}-0.023 \\
(0.102)\end{array}$ & $\begin{array}{c}0.088 \\
(0.129)\end{array}$ & $\begin{array}{c}0.087 \\
(0.127)\end{array}$ & $\begin{array}{c}0.088 \\
(0.129)\end{array}$ & $\begin{array}{c}0.079 \\
(0.128)\end{array}$ & $\begin{array}{c}0.087 \\
(0.127)\end{array}$ \\
\hline IND_1 & $-0.405^{\star *}$ & $-0.419^{\star *}$ & $-0.403^{\star *}$ & $-0.406^{\star *}$ & $-0.389^{\star *}$ & -0.188 & -0.166 & -0.170 & -0.239 & -0.183 & 0.223 & 0.255 & 0.277 & 0.192 & 0.243 \\
\hline
\end{tabular}




\begin{tabular}{|c|c|c|c|c|c|c|c|c|c|c|c|c|c|c|c|}
\hline & $(0.167)$ & $(0.167)$ & $(0.167)$ & $(0.168)$ & $(0.167)$ & $(0.237)$ & $(0.238)$ & $(0.236)$ & $(0.237)$ & $(0.237)$ & $(0.316)$ & $(0.318)$ & $(0.316)$ & $(0.312)$ & $(0.310)$ \\
\hline IND_2 & 0.174 & 0.163 & 0.173 & 0.199 & 0.216 & -0.089 & -0.070 & -0.072 & -0.118 & -0.082 & 0.029 & 0.040 & 0.078 & 0.041 & 0.098 \\
\hline & $(0.139)$ & (0.139) & $(0.139)$ & $(0.138)$ & (0.138) & (0.188) & (0.188) & (0.188) & $(0.190)$ & $(0.190)$ & $(0.242)$ & $(0.245)$ & $(0.239)$ & $(0.239)$ & $(0.235)$ \\
\hline IND_3 & $\begin{array}{c}-0.332^{\star \star} \\
(0.135)\end{array}$ & $\begin{array}{c}-0.345^{\star \star} \\
(0.135)\end{array}$ & $\begin{array}{c}-0.342^{\star \star} \\
(0.135)\end{array}$ & $\begin{array}{c}-0.327^{\star \star} \\
(0.135)\end{array}$ & $\begin{array}{c}-0.314^{\star *} \\
(0.134)\end{array}$ & $\begin{array}{l}-0.003 \\
(0.184)\end{array}$ & $\begin{array}{c}0.007 \\
(0.186)\end{array}$ & $\begin{array}{l}-0.004 \\
(0.185)\end{array}$ & $\begin{array}{l}-0.047 \\
(0.185)\end{array}$ & $\begin{array}{l}-0.021 \\
(0.186)\end{array}$ & $\begin{array}{l}-0.104 \\
(0.242)\end{array}$ & $\begin{array}{l}-0.083 \\
(0.243)\end{array}$ & $\begin{array}{l}-0.083 \\
(0.241)\end{array}$ & $\begin{array}{l}-0.133 \\
(0.239)\end{array}$ & $\begin{array}{l}-0.110 \\
(0.236)\end{array}$ \\
\hline DEBT_CONST & $\begin{array}{c}-0.062^{\star \star \star} \\
(0.014)\end{array}$ & & & & & $\begin{array}{c}-0.053^{\star \star \star} \\
(0.018)\end{array}$ & & & & & $\begin{array}{c}-0.086^{\star \star *} \\
(0.024)\end{array}$ & & & & \\
\hline CRED_COND & & $\begin{array}{c}-0.098^{\star \star \star} \\
(0.023)\end{array}$ & & & & & $\begin{array}{c}-0.077^{\star \star} \\
(0.034)\end{array}$ & & & & & $\begin{array}{c}-0.158^{\star \star *} \\
(0.045)\end{array}$ & & & \\
\hline CRED_LINE & & & $\begin{array}{c}-0.105^{\star * *} \\
(0.024)\end{array}$ & & & & & $\begin{array}{c}-0.092^{* *} \\
(0.036)\end{array}$ & & & & & $\begin{array}{c}-0.159^{* * *} \\
(0.047)\end{array}$ & & \\
\hline DEBT_INFO & & & & $\begin{array}{c}-0.088^{\star \star \star} \\
(0.027)\end{array}$ & & & & & $\begin{array}{c}-0.104^{\star *} \\
(0.042)\end{array}$ & & & & & $\begin{array}{c}-0.167^{\star \star \star} \\
(0.061)\end{array}$ & \\
\hline VC_CONST & & & & & $\begin{array}{c}-0.095^{\star * *} \\
(0.030) \\
\end{array}$ & & & & & $\begin{array}{c}-0.098^{\star *} \\
(0.043) \\
\end{array}$ & & & & & $\begin{array}{c}-0.122^{\star *} \\
(0.062)\end{array}$ \\
\hline $\mathrm{N}$ & 1589 & 1589 & 1589 & 1589 & 1589 & 911 & 911 & 911 & 911 & 911 & 615 & 615 & 615 & 615 & 615 \\
\hline Pseudo $R^{2}$ & 0.072 & 0.070 & 0.071 & 0.066 & 0.065 & 0.050 & 0.047 & 0.049 & 0.049 & 0.047 & 0.081 & 0.080 & 0.078 & 0.070 & 0.063 \\
\hline Wald chi ${ }^{2}$ & $122.13^{\star \star *}$ & $118.96^{\star * *}$ & $121.09^{\star \star *}$ & $112.79^{\star * \star}$ & $113.31^{\star * *}$ & $47.35^{\star * *}$ & $44.65^{\star * *}$ & $46.12^{* \star *}$ & $43.70^{\star * *}$ & $44.14^{* * *}$ & $36.71^{* * *}$ & $36.83^{* * *}$ & $36.05^{\star *}$ & $31.73^{\star \star}$ & $29.63^{*}$ \\
\hline
\end{tabular}

Notes: see table 3 for the variable definitions; heteroskedasticity-robust standard errors (White procedure) are in brackets under the coefficients; $* * *, * *, *$ denotes statistical significance at the $1 \%, 5 \%$ and $10 \%$ test level, respectively. 
Table 9: Growth of start-ups; weighted OLS

\begin{tabular}{|c|c|c|c|c|c|c|c|c|c|c|c|c|c|c|c|}
\hline Period & & GROV & /TH 1996/9 & -2000 & & & GRC & WTH 2000 & 2003 & & & GRC & NTH 2003 & 2006 & \\
\hline Explanatory variables & $(1)$ & (2) & (3) & (4) & (5) & (1) & (2) & (3) & (4) & (5) & (1) & (2) & (3) & (4) & (5) \\
\hline CONSTANT & $\begin{array}{c}0.750^{\star \star *} \\
(0.260)\end{array}$ & $\begin{array}{c}0.721^{\star * *} \\
(0.265)\end{array}$ & $\begin{array}{c}0.725^{\star * *} \\
(0.263)\end{array}$ & $\begin{array}{c}0.777^{\star \star \star} \\
(0.261)\end{array}$ & $\begin{array}{c}0.783^{* * *} \\
(0.261)\end{array}$ & $\begin{array}{c}0.918^{\star * *} \\
(0.311)\end{array}$ & $\begin{array}{c}0.924^{* \star *} \\
(0.311)\end{array}$ & $\begin{array}{c}0.934^{\star * *} \\
(0.311)\end{array}$ & $\begin{array}{c}0.969^{\star * *} \\
(0.312)\end{array}$ & $\begin{array}{c}0.947^{\star * *} \\
(0.312)\end{array}$ & $\begin{array}{l}0.755^{*} \\
(0.422)\end{array}$ & $\begin{array}{l}0.770^{\star} \\
(0.423)\end{array}$ & $\begin{array}{c}0.797^{\star} \\
(0.426)\end{array}$ & $\begin{array}{l}0.753^{*} \\
(0.432)\end{array}$ & $\begin{array}{l}0.701^{*} \\
(0.422)\end{array}$ \\
\hline MAIN & $\begin{array}{c}0.152^{\star \star \star} \\
(0.047)\end{array}$ & $\begin{array}{c}0.152^{\star \star *} \\
(0.047)\end{array}$ & $\begin{array}{c}0.151^{\star * *} \\
(0.047)\end{array}$ & $\begin{array}{c}0.153^{* \star *} \\
(0.047)\end{array}$ & $\begin{array}{c}0.153^{\star \star \star *} \\
(0.047)\end{array}$ & $\begin{array}{c}0.000 \\
(0.063)\end{array}$ & $\begin{array}{c}0.000 \\
(0.063)\end{array}$ & $\begin{array}{c}0.001 \\
(0.063)\end{array}$ & $\begin{array}{l}-0.003 \\
(0.063)\end{array}$ & $\begin{array}{l}-0.002 \\
(0.063)\end{array}$ & $\begin{array}{c}0.019 \\
(0.082)\end{array}$ & $\begin{array}{c}0.021 \\
(0.083)\end{array}$ & $\begin{array}{c}0.018 \\
(0.082)\end{array}$ & $\begin{array}{c}0.017 \\
(0.082)\end{array}$ & $\begin{array}{c}0.016 \\
(0.082)\end{array}$ \\
\hline UNEMPLOY & $\begin{array}{c}-0.106^{\star \star \star} \\
(0.037)\end{array}$ & $\begin{array}{c}-0.105^{\star \star \star} \\
(0.036)\end{array}$ & $\begin{array}{c}-0.107^{\star \star \star} \\
(0.037)\end{array}$ & $\begin{array}{c}-0.104^{\star * *} \\
(0.037)\end{array}$ & $\begin{array}{c}-0.104^{* * *} \\
(0.036)\end{array}$ & $\begin{array}{l}-0.011 \\
(0.051)\end{array}$ & $\begin{array}{l}-0.013 \\
(0.051)\end{array}$ & $\begin{array}{l}-0.012 \\
(0.051)\end{array}$ & $\begin{array}{l}-0.009 \\
(0.050)\end{array}$ & $\begin{array}{l}-0.010 \\
(0.050)\end{array}$ & $\begin{array}{c}-0.071 \\
(0.054)\end{array}$ & $\begin{array}{l}-0.072 \\
(0.055)\end{array}$ & $\begin{array}{l}-0.071 \\
(0.053)\end{array}$ & $\begin{array}{l}-0.076 \\
(0.054)\end{array}$ & $\begin{array}{l}-0.081 \\
(0.053)\end{array}$ \\
\hline LAGE & $\begin{array}{c}-0.136^{* *} \\
(0.068)\end{array}$ & $\begin{array}{c}-0.136^{\star *} \\
(0.068)\end{array}$ & $\begin{array}{c}-0.136^{\star \star} \\
(0.068)\end{array}$ & $\begin{array}{c}-0.146^{\star *} \\
(0.068)\end{array}$ & $\begin{array}{c}-0.147^{\star \star} \\
(0.067)\end{array}$ & $\begin{array}{c}-0.221^{* \star \star} \\
(0.081)\end{array}$ & $\begin{array}{c}-0.221^{\star \star \star} \\
(0.081)\end{array}$ & $\begin{array}{c}-0.221^{\star * *} \\
(0.081)\end{array}$ & $\begin{array}{c}-0.218^{\star \star \star} \\
(0.080)\end{array}$ & $\begin{array}{c}-0.221^{\star * *} \\
(0.081)\end{array}$ & $\begin{array}{c}-0.219^{\star *} \\
(0.110)\end{array}$ & $\begin{array}{l}-0.215^{\star} \\
(0.110)\end{array}$ & $\begin{array}{c}-0.219^{\star \star} \\
(0.110)\end{array}$ & $\begin{array}{l}-0.213^{*} \\
(0.110)\end{array}$ & $\begin{array}{l}-0.205^{*} \\
(0.108)\end{array}$ \\
\hline GENDER & $\begin{array}{l}-0.026 \\
(0.034)\end{array}$ & $\begin{array}{l}-0.026 \\
(0.034)\end{array}$ & $\begin{array}{l}-0.027 \\
(0.034)\end{array}$ & $\begin{array}{l}-0.025 \\
(0.034)\end{array}$ & $\begin{array}{l}-0.025 \\
(0.034)\end{array}$ & $\begin{array}{c}0.035 \\
(0.043)\end{array}$ & $\begin{array}{c}0.034 \\
(0.043)\end{array}$ & $\begin{array}{c}0.035 \\
(0.043)\end{array}$ & $\begin{array}{c}0.038 \\
(0.043)\end{array}$ & $\begin{array}{c}0.036 \\
(0.043)\end{array}$ & $\begin{array}{c}0.011 \\
(0.048)\end{array}$ & $\begin{array}{c}0.010 \\
(0.048)\end{array}$ & $\begin{array}{c}0.011 \\
(0.048)\end{array}$ & $\begin{array}{c}0.012 \\
(0.048)\end{array}$ & $\begin{array}{c}0.011 \\
(0.049)\end{array}$ \\
\hline QUAL & $\begin{array}{c}0.085^{\star \star \star} \\
(0.031)\end{array}$ & $\begin{array}{c}0.085^{\star \star *} \\
(0.031)\end{array}$ & $\begin{array}{c}0.086^{\star * *} \\
(0.031)\end{array}$ & $\begin{array}{c}0.083^{* * *} \\
(0.031)\end{array}$ & $\begin{array}{c}0.083^{\star * *} \\
(0.031)\end{array}$ & $\begin{array}{l}0.090^{* *} \\
(0.040)\end{array}$ & $\begin{array}{l}0.092^{* *} \\
(0.040)\end{array}$ & $\begin{array}{l}0.090^{\star *} \\
(0.040)\end{array}$ & $\begin{array}{l}0.088^{* *} \\
(0.040)\end{array}$ & $\begin{array}{l}0.093^{\star *} \\
(0.040)\end{array}$ & $\begin{array}{c}0.072 \\
(0.047)\end{array}$ & $\begin{array}{c}0.071 \\
(0.048)\end{array}$ & $\begin{array}{c}0.069 \\
(0.047)\end{array}$ & $\begin{array}{c}0.075 \\
(0.047)\end{array}$ & $\begin{array}{c}0.075 \\
(0.047)\end{array}$ \\
\hline$R \& D$ & $\begin{array}{c}0.040 \\
(0.040)\end{array}$ & $\begin{array}{c}0.042 \\
(0.040)\end{array}$ & $\begin{array}{c}0.040 \\
(0.040)\end{array}$ & $\begin{array}{c}0.043 \\
(0.040)\end{array}$ & $\begin{array}{c}0.043 \\
(0.041)\end{array}$ & $\begin{array}{c}0.026 \\
(0.044)\end{array}$ & $\begin{array}{c}0.023 \\
(0.044)\end{array}$ & $\begin{array}{c}0.024 \\
(0.044)\end{array}$ & $\begin{array}{c}0.031 \\
(0.044)\end{array}$ & $\begin{array}{c}0.025 \\
(0.044)\end{array}$ & $\begin{array}{l}-0.046 \\
(0.068)\end{array}$ & $\begin{array}{l}-0.049 \\
(0.068)\end{array}$ & $\begin{array}{l}-0.046 \\
(0.068)\end{array}$ & $\begin{array}{l}-0.049 \\
(0.068)\end{array}$ & $\begin{array}{l}-0.052 \\
(0.068)\end{array}$ \\
\hline NP & $\begin{array}{l}0.090^{* *} \\
(0.043)\end{array}$ & $\begin{array}{l}0.089^{* *} \\
(0.043)\end{array}$ & $\begin{array}{l}0.090^{* *} \\
(0.043)\end{array}$ & $\begin{array}{l}0.093^{* *} \\
(0.043)\end{array}$ & $\begin{array}{l}0.093^{* *} \\
(0.043)\end{array}$ & $\begin{array}{l}0.127^{\star *} \\
(0.056)\end{array}$ & $\begin{array}{l}0.126^{\star *} \\
(0.056)\end{array}$ & $\begin{array}{l}0.127^{\star *} \\
(0.056)\end{array}$ & $\begin{array}{l}0.126^{* *} \\
(0.056)\end{array}$ & $\begin{array}{l}0.127^{\star \star} \\
(0.056)\end{array}$ & $\begin{array}{l}0.131^{* *} \\
(0.066)\end{array}$ & $\begin{array}{l}0.129^{* *} \\
(0.065)\end{array}$ & $\begin{array}{l}0.129^{* *} \\
(0.065)\end{array}$ & $\begin{array}{l}0.128^{*} \\
(0.067)\end{array}$ & $\begin{array}{l}0.123^{\star} \\
(0.067)\end{array}$ \\
\hline MP & $\begin{array}{c}0.090^{* \star *} \\
(0.032)\end{array}$ & $\begin{array}{c}0.090^{\star * *} \\
(0.032)\end{array}$ & $\begin{array}{c}0.089^{* * *} \\
(0.032)\end{array}$ & $\begin{array}{c}0.091^{* * *} \\
(0.032)\end{array}$ & $\begin{array}{c}0.091^{* * *} \\
(0.032)\end{array}$ & $\begin{array}{c}0.031 \\
(0.036)\end{array}$ & $\begin{array}{c}0.029 \\
(0.036)\end{array}$ & $\begin{array}{c}0.031 \\
(0.036)\end{array}$ & $\begin{array}{c}0.033 \\
(0.035)\end{array}$ & $\begin{array}{c}0.031 \\
(0.035)\end{array}$ & $\begin{array}{c}0.152^{* * *} \\
(0.045)\end{array}$ & $\begin{array}{c}0.152^{* * *} \\
(0.046)\end{array}$ & $\begin{array}{c}0.151^{* * *} \\
(0.045)\end{array}$ & $\begin{array}{c}0.151^{* * *} \\
(0.045)\end{array}$ & $\begin{array}{c}0.149^{* * *} \\
(0.045)\end{array}$ \\
\hline PCOMP & $\begin{array}{l}-0.007 \\
(0.029)\end{array}$ & $\begin{array}{l}-0.007 \\
(0.029)\end{array}$ & $\begin{array}{l}-0.008 \\
(0.029)\end{array}$ & $\begin{array}{l}-0.005 \\
(0.029)\end{array}$ & $\begin{array}{l}-0.005 \\
(0.029)\end{array}$ & $\begin{array}{c}0.055 \\
(0.036)\end{array}$ & $\begin{array}{c}0.051 \\
(0.036)\end{array}$ & $\begin{array}{c}0.053 \\
(0.036)\end{array}$ & $\begin{array}{c}0.058 \\
(0.036)\end{array}$ & $\begin{array}{c}0.052 \\
(0.036)\end{array}$ & $\begin{array}{l}-0.003 \\
(0.042)\end{array}$ & $\begin{array}{c}0.000 \\
(0.042)\end{array}$ & $\begin{array}{l}-0.004 \\
(0.042)\end{array}$ & $\begin{array}{l}-0.004 \\
(0.043)\end{array}$ & $\begin{array}{l}-0.002 \\
(0.042)\end{array}$ \\
\hline NPCOMP & $\begin{array}{c}0.004 \\
(0.030)\end{array}$ & $\begin{array}{c}0.004 \\
(0.030)\end{array}$ & $\begin{array}{c}0.005 \\
(0.030)\end{array}$ & $\begin{array}{c}0.004 \\
(0.030)\end{array}$ & $\begin{array}{c}0.004 \\
(0.030)\end{array}$ & $\begin{array}{l}0.087^{* *} \\
(0.036)\end{array}$ & $\begin{array}{l}0.086^{\star *} \\
(0.036)\end{array}$ & $\begin{array}{l}0.087^{\star *} \\
(0.036)\end{array}$ & $\begin{array}{l}0.086^{* *} \\
(0.036)\end{array}$ & $\begin{array}{l}0.087^{\star *} \\
(0.036)\end{array}$ & $\begin{array}{c}-0.025 \\
(0.041)\end{array}$ & $\begin{array}{l}-0.027 \\
(0.041)\end{array}$ & $\begin{array}{l}-0.023 \\
(0.041)\end{array}$ & $\begin{array}{l}-0.026 \\
(0.041)\end{array}$ & $\begin{array}{l}-0.026 \\
(0.041)\end{array}$ \\
\hline LCAP & $\begin{array}{l}0.015^{\star} \\
(0.008)\end{array}$ & $\begin{array}{l}0.015^{*} \\
(0.008)\end{array}$ & $\begin{array}{l}0.014^{*} \\
(0.008)\end{array}$ & $\begin{array}{l}0.015^{*} \\
(0.008)\end{array}$ & $\begin{array}{l}0.015^{\star} \\
(0.008)\end{array}$ & $\begin{array}{c}0.007 \\
(0.009)\end{array}$ & $\begin{array}{c}0.007 \\
(0.009)\end{array}$ & $\begin{array}{c}0.007 \\
(0.009)\end{array}$ & $\begin{array}{c}0.007 \\
(0.009)\end{array}$ & $\begin{array}{c}0.007 \\
(0.009)\end{array}$ & $\begin{array}{c}0.008 \\
(0.011)\end{array}$ & $\begin{array}{c}0.008 \\
(0.011)\end{array}$ & $\begin{array}{c}0.008 \\
(0.011)\end{array}$ & $\begin{array}{c}0.008 \\
(0.011)\end{array}$ & $\begin{array}{c}0.009 \\
(0.011)\end{array}$ \\
\hline$A G$ & $\begin{array}{c}0.502^{\star \star \star} \\
(0.062)\end{array}$ & $\begin{array}{c}0.501^{\star * \star} \\
(0.062)\end{array}$ & $\begin{array}{c}0.501^{* * *} \\
(0.062)\end{array}$ & $\begin{array}{c}0.504^{\star \star \star} \\
(0.062)\end{array}$ & $\begin{array}{c}0.504^{\star * *} \\
(0.062)\end{array}$ & $\begin{array}{c}0.289^{* \star *} \\
(0.058)\end{array}$ & $\begin{array}{c}0.289^{\star \star \star} \\
(0.058)\end{array}$ & $\begin{array}{c}0.290^{\star \star \star} \\
(0.058)\end{array}$ & $\begin{array}{c}0.287^{\star * *} \\
(0.058)\end{array}$ & $\begin{array}{c}0.292^{\star \star \star} \\
(0.058)\end{array}$ & $\begin{array}{l}0.142^{* *} \\
(0.072)\end{array}$ & $\begin{array}{l}0.145^{\star \star} \\
(0.072)\end{array}$ & $\begin{array}{l}0.139^{*} \\
(0.071)\end{array}$ & $\begin{array}{l}0.144^{* *} \\
(0.072)\end{array}$ & $\begin{array}{l}0.145^{\star *} \\
(0.072)\end{array}$ \\
\hline GMBH & $\begin{array}{c}0.108^{\star \star *} \\
(0.035)\end{array}$ & $\begin{array}{c}0.107^{* * *} \\
(0.035)\end{array}$ & $\begin{array}{c}0.108^{\star * *} \\
(0.035)\end{array}$ & $\begin{array}{c}0.110^{* * *} \\
(0.035)\end{array}$ & $\begin{array}{c}0.110^{\star \star *} \\
(0.035)\end{array}$ & $\begin{array}{c}0.131^{* * *} \\
(0.041)\end{array}$ & $\begin{array}{c}0.129^{* * *} \\
(0.041)\end{array}$ & $\begin{array}{c}0.129^{* * *} \\
(0.041)\end{array}$ & $\begin{array}{c}0.136^{* * *} \\
(0.041)\end{array}$ & $\begin{array}{c}0.132^{* * *} \\
(0.041)\end{array}$ & $\begin{array}{c}0.042 \\
(0.050)\end{array}$ & $\begin{array}{c}0.041 \\
(0.050)\end{array}$ & $\begin{array}{c}0.040 \\
(0.050)\end{array}$ & $\begin{array}{c}0.041 \\
(0.050)\end{array}$ & $\begin{array}{c}0.037 \\
(0.051)\end{array}$ \\
\hline OTHER & $\begin{array}{l}-0.012 \\
(0.044)\end{array}$ & $\begin{array}{l}-0.012 \\
(0.044)\end{array}$ & $\begin{array}{l}-0.012 \\
(0.044)\end{array}$ & $\begin{array}{l}-0.012 \\
(0.044)\end{array}$ & $\begin{array}{l}-0.012 \\
(0.044)\end{array}$ & $\begin{array}{c}0.024 \\
(0.120)\end{array}$ & $\begin{array}{c}0.028 \\
(0.119)\end{array}$ & $\begin{array}{c}0.025 \\
(0.120)\end{array}$ & $\begin{array}{c}0.023 \\
(0.120)\end{array}$ & $\begin{array}{c}0.029 \\
(0.120)\end{array}$ & $\begin{array}{c}0.193 \\
(0.132)\end{array}$ & $\begin{array}{c}0.191 \\
(0.132)\end{array}$ & $\begin{array}{c}0.189 \\
(0.132)\end{array}$ & $\begin{array}{c}0.192 \\
(0.130)\end{array}$ & $\begin{array}{c}0.186 \\
(0.129)\end{array}$ \\
\hline LSIZE & $\begin{array}{c}-0.349^{\star \star \star} \\
(0.046)\end{array}$ & $\begin{array}{c}-0.348^{\star \star \star} \\
(0.047)\end{array}$ & $\begin{array}{c}-0.350^{\star \star \star} \\
(0.046)\end{array}$ & $\begin{array}{c}-0.347^{\star \star *} \\
(0.046)\end{array}$ & $\begin{array}{c}-0.347^{\star \star \star} \\
(0.046)\end{array}$ & $\begin{array}{c}-0.213^{\star \star \star} \\
(0.049)\end{array}$ & $\begin{array}{c}-0.214^{\star \star \star} \\
(0.049)\end{array}$ & $\begin{array}{c}-0.213^{\star * *} \\
(0.049)\end{array}$ & $\begin{array}{c}-0.212^{\star \star \star} \\
(0.048)\end{array}$ & $\begin{array}{c}-0.213^{\star * *} \\
(0.049)\end{array}$ & $\begin{array}{l}-0.091^{*} \\
(0.055)\end{array}$ & $\begin{array}{l}-0.091^{*} \\
(0.054)\end{array}$ & $\begin{array}{l}-0.090 \\
(0.055)\end{array}$ & $\begin{array}{l}-0.093^{*} \\
(0.055)\end{array}$ & $\begin{array}{l}-0.093^{*} \\
(0.055)\end{array}$ \\
\hline IND_1 & $\begin{array}{c}-0.193^{* * \star} \\
(0.066)\end{array}$ & $\begin{array}{c}-0.192^{* * *} \\
(0.066)\end{array}$ & $\begin{array}{c}-0.194^{* * *} \\
(0.066)\end{array}$ & $\begin{array}{c}-0.191^{\star * *} \\
(0.066)\end{array}$ & $\begin{array}{c}-0.191^{* * *} \\
(0.066)\end{array}$ & $\begin{array}{l}-0.122 \\
(0.085)\end{array}$ & $\begin{array}{l}-0.126 \\
(0.085)\end{array}$ & $\begin{array}{l}-0.123 \\
(0.085)\end{array}$ & $\begin{array}{l}-0.134 \\
(0.084)\end{array}$ & $\begin{array}{l}-0.121 \\
(0.085)\end{array}$ & $\begin{array}{c}0.009 \\
(0.094)\end{array}$ & $\begin{array}{c}0.011 \\
(0.094)\end{array}$ & $\begin{array}{c}0.014 \\
(0.096)\end{array}$ & $\begin{array}{c}0.009 \\
(0.094)\end{array}$ & $\begin{array}{c}0.015 \\
(0.098)\end{array}$ \\
\hline IND_2 & $\begin{array}{c}-0.249^{* * *} \\
(0.052)\end{array}$ & $\begin{array}{c}-0.247^{\star * *} \\
(0.052)\end{array}$ & $\begin{array}{c}-0.248^{\star * *} \\
(0.052)\end{array}$ & $\begin{array}{c}-0.252^{\star * *} \\
(0.052)\end{array}$ & $\begin{array}{c}-0.252^{* * *} \\
(0.052)\end{array}$ & $\begin{array}{c}-0.154^{* *} \\
(0.060)\end{array}$ & $\begin{array}{c}-0.153^{* *} \\
(0.060)\end{array}$ & $\begin{array}{c}-0.152^{* *} \\
(0.060)\end{array}$ & $\begin{array}{c}-0.164^{* \star *} \\
(0.060)\end{array}$ & $\begin{array}{c}-0.153^{* *} \\
(0.060)\end{array}$ & $\begin{array}{l}-0.109 \\
(0.089)\end{array}$ & $\begin{array}{l}-0.108 \\
(0.088)\end{array}$ & $\begin{array}{l}-0.105 \\
(0.090)\end{array}$ & $\begin{array}{l}-0.104 \\
(0.090)\end{array}$ & $\begin{array}{l}-0.098 \\
(0.094)\end{array}$ \\
\hline
\end{tabular}




\begin{tabular}{|c|c|c|c|c|c|c|c|c|c|c|c|c|c|c|c|}
\hline IND_3 & $\begin{array}{c}-0.170^{\star * \star} \\
(0.051)\end{array}$ & $\begin{array}{c}-0.169^{* * *} \\
(0.051)\end{array}$ & $\begin{array}{c}-0.169^{\star \star \star} \\
(0.051)\end{array}$ & $\begin{array}{c}-0.168^{* \star \star} \\
(0.051)\end{array}$ & $\begin{array}{c}-0.168^{* \star *} \\
(0.051)\end{array}$ & $\begin{array}{l}-0.077 \\
(0.060)\end{array}$ & $\begin{array}{l}-0.083 \\
(0.060)\end{array}$ & $\begin{array}{l}-0.079 \\
(0.060)\end{array}$ & $\begin{array}{l}-0.083 \\
(0.060)\end{array}$ & $\begin{array}{l}-0.078 \\
(0.060)\end{array}$ & $\begin{array}{l}-0.073 \\
(0.086)\end{array}$ & $\begin{array}{l}-0.072 \\
(0.087)\end{array}$ & $\begin{array}{l}-0.071 \\
(0.087)\end{array}$ & $\begin{array}{l}-0.074 \\
(0.087)\end{array}$ & $\begin{array}{l}-0.071 \\
(0.089)\end{array}$ \\
\hline DEBT_CONST & $\begin{array}{c}0.007 \\
(0.006)\end{array}$ & & & & & $\begin{array}{l}-0.006 \\
(0.008)\end{array}$ & & & & & $\begin{array}{l}-0.010 \\
(0.010)\end{array}$ & & & & \\
\hline CRED_COND & & $\begin{array}{c}0.013 \\
(0.010)\end{array}$ & & & & & $\begin{array}{c}0.003 \\
(0.013)\end{array}$ & & & & & $\begin{array}{l}-0.017 \\
(0.018)\end{array}$ & & & \\
\hline CRED_LINE & & & $\begin{array}{c}0.015 \\
(0.010)\end{array}$ & & & & & $\begin{array}{l}-0.006 \\
(0.014)\end{array}$ & & & & & $\begin{array}{l}-0.022 \\
(0.018)\end{array}$ & & \\
\hline DEBT_INFO & & & & $\begin{array}{c}0.002 \\
(0.011)\end{array}$ & & & & & $\begin{array}{l}-0.030^{*} \\
(0.018)\end{array}$ & & & & & $\begin{array}{l}-0.013 \\
(0.024)\end{array}$ & \\
\hline VC_CONST & & & & & $\begin{array}{c}0.001 \\
(0.012)\end{array}$ & & & & & $\begin{array}{l}-0.017 \\
(0.018)\end{array}$ & & & & & $\begin{array}{l}-0.001 \\
(0.024) \\
\end{array}$ \\
\hline $\mathrm{N}$ & 1589 & 1589 & 1589 & 1589 & 1589 & 911 & 911 & 911 & 911 & 911 & 615 & 615 & 615 & 615 & 615 \\
\hline$R^{2}$ & 0.140 & 0.141 & 0.141 & 0.140 & 0.140 & 0.085 & 0.084 & 0.084 & 0.088 & 0.085 & 0.060 & 0.060 & 0.061 & 0.058 & 0.057 \\
\hline $\mathrm{F}$ & $8.23^{\star \star \star}$ & $8.24^{\star \star \star}$ & $8.30^{* \star *}$ & $8.12^{\star \star \star}$ & $8.19^{\star \star \star}$ & $3.78^{\star \star \star}$ & $3.82^{\star \star \star}$ & $3.81^{* \star *}$ & $3.87^{* * *}$ & $3.86^{\star \star \star}$ & $1.58^{\star}$ & $1.58^{\star}$ & $1.60^{*}$ & $1.55^{\star}$ & $1.54^{\star}$ \\
\hline
\end{tabular}

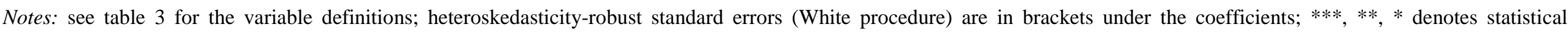
significance at the $1 \%, 5 \%$ and $10 \%$ test level, respectively. 


\section{APPENDIX:}

Table A.1: Composition of data set by industry, firm size and region

\begin{tabular}{|c|c|c|c|c|c|c|}
\hline Year & & 2000 & & 2003 & & 2006 \\
\hline Industry / sector & $\mathrm{N}$ & $\begin{array}{c}\text { Percentage } \\
\text { of firms }\end{array}$ & $\mathrm{N}$ & $\begin{array}{l}\text { Percentage } \\
\text { of firms }\end{array}$ & $\mathrm{N}$ & $\begin{array}{c}\text { Percentage } \\
\text { of firms }\end{array}$ \\
\hline Food & 6 & 0.4 & $3:$ & 0.3 & 1 & 0.2 \\
\hline Textiles, clothing's, leather & 7 & 0.4 & 3 & 0.3 & 3 & 0.5 \\
\hline Wood processing, paper, printing & 43 & 2.7 & 20 & 2.2 & 15 & 2.4 \\
\hline Chemicals, plastics, glass & 19 & 1.2 & $12 \vdots$ & 1.3 & 9 & 1.5 \\
\hline Metal, metalworking & 21 & 1.3 & 13 & 1.4 & 7 & 1.1 \\
\hline Machinery, vehicles & 7 & 0.4 & 4 & 0.4 & 4 & 0.7 \\
\hline Electrical machinery, electronics, watches & 18 & 1.1 & 12 & 1.3 & 6 & 1.0 \\
\hline Other manufacturing & 13 & 0.8 & 6 & 0.7 & 5 & 0.8 \\
\hline Manufacturing & 134 & 8.4 & 73 & 8.0 & 50 & 8.1 \\
\hline - High-tech manufacturing & 37 & 2.3 & 23 & 2.5 & 17 & 2.8 \\
\hline - Low-tech manufacturing & 97 & 6.1 & 50 & 5.5 & 33 & 5.4 \\
\hline Construction & 148 & 9.3 & 82 & 9.0 & 57 & 9.3 \\
\hline Wholesale trade & 134 & 8.4 & 65 & 7.1 & 42 & 6.8 \\
\hline Retail trade & 212 & 13.3 & 121 & 13.3 & 70 & 11.4 \\
\hline Hotels, catering & 20 & 1.3 & 11 & 1.2 & 4 & 0.7 \\
\hline Transport, telecommunication & 42 & 2.6 & 27 & 3.0 & 10 & 1.6 \\
\hline Banks, insurance & 25 & 1.6 & 14 & 1.5 & 7 & 1.1 \\
\hline Real estate, leasing, computer services & 197 & 12.4 & 103 & 11.3 & 74 & 12.0 \\
\hline Business services & 565 & 35.6 & 351 & 38.5 & 259 & 42.1 \\
\hline Educational system & 24 & 1.5 & 17 & 1.9 & 9 & 1.5 \\
\hline Health care & 25 & 1.6 & 16 & 1.8 & 12 & 2.0 \\
\hline Other services & 39 & 2.5 & 21 & 2.3 & 14 & 2.3 \\
\hline Culture/sport/amusement & 24 & 1.5 & 10 & 1.1 & 7 & 1.1 \\
\hline Services & 1307 & 82.3 & 756 & 83.0 & 508 & 82.6 \\
\hline - Modern services & 705 & 44.4 & 421 & 46.2 & 311 & 50.6 \\
\hline - Traditional services & 602 & 37.9 & 335 & 36.8 & 197 & 32.0 \\
\hline \multicolumn{7}{|l|}{ Firm Size (number of employees) } \\
\hline up to 1 employee & 658 & 41.4 & 331 & 36.3 & 212 & 34.5 \\
\hline 1 up to and including 2 employees & 442 & 27.8 & 253 & 27.8 & 176 & 28.6 \\
\hline 2 up to and including 4 employees & 275 & 17.3 & 175 & 19.2 & 109 & 17.7 \\
\hline 4 up to and including 10 employees & 162 & 10.2 & 109 & 12.0 & 77 & 12.5 \\
\hline 10 up to and including 20 employees & 34 & 2.1 & 29 & 3.2 & 29 & 4.7 \\
\hline more than 20 employees & 18 & 1.1 & 14 & 1.5 & 12 & 2.0 \\
\hline \multicolumn{7}{|l|}{ Region } \\
\hline Lac Léman region & 173 & 10.9 & 98 & 10.8 & 56 & 9.1 \\
\hline Espace midland & 311 & 19.6 & 192 & 21.1 & 138 & 22.4 \\
\hline North-western Switzerland & 244 & 15.4 & 125 & 13.7 & 98 & 15.9 \\
\hline Zurich & 395 & 24.9 & 223 & 24.5 & 151 & 24.6 \\
\hline Eastern Switzerland & 235 & 14.8 & 133 & 14.6 & 87 & 14.1 \\
\hline Central Switzerland & 191 & 12.0 & 113 & 12.4 & 68 & 11.1 \\
\hline Ticino & 40 & 2.5 & 27 & 3.0 & 17 & 2.8 \\
\hline $\mathrm{N}$ & 1589 & 100 & 911 & 100 & 615 & 100 \\
\hline
\end{tabular}

Note: High-tech manufacturing: chemicals; plastics; machinery; electrical machinery; electronics and instruments; vehicles; low-tech manufacturing: all other manufacturing industries; modern services: banking and insurance; computer services; other business services; traditional services: all other service industries. 
Table A.2: Test for selective attrition (selection indicator included in success models)

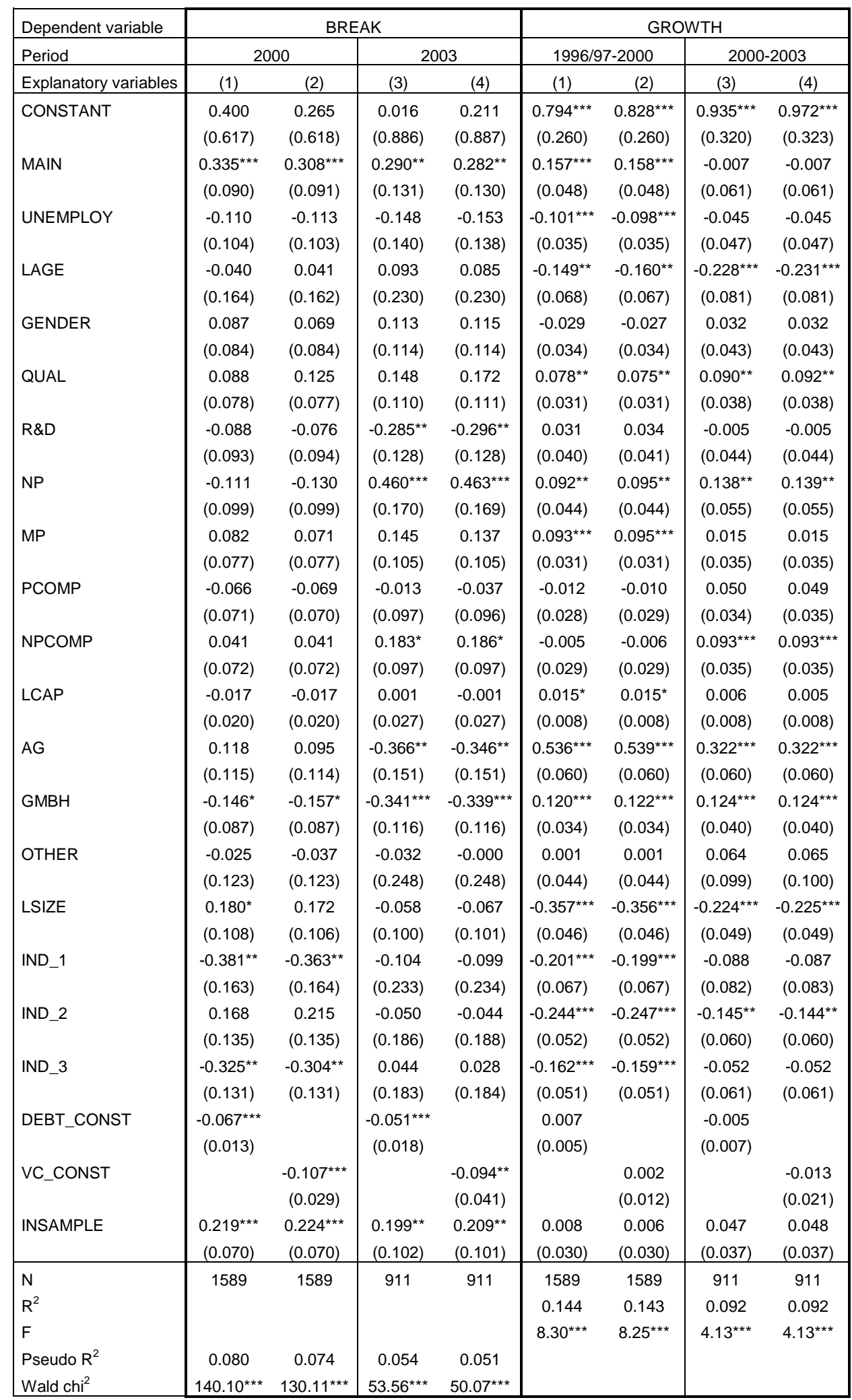

Notes: see table 3 for the variable definitions; heteroskedasticity-robust standard errors (White procedure) are in brackets under the coefficients; ***, **, * denotes statistical significance at the $1 \%, 5 \%$ and $10 \%$ test level, respectively. 
Table A.3: Estimates include interaction terms for DEBT_CONST

\begin{tabular}{|c|c|c|c|c|c|c|}
\hline \multirow{3}{*}{$\begin{array}{l}\text { Dependent variable } \\
\text { Period } \\
\text { Explanatory variables } \\
\end{array}$} & \multicolumn{3}{|c|}{ BREAK } & \multicolumn{3}{|c|}{ GROWTH } \\
\hline & \multicolumn{2}{|c|}{2000} & \multirow{2}{*}{$\begin{array}{c}2003 \\
(3) \\
\end{array}$} & \multicolumn{2}{|c|}{$1996 / 97-2000$} & \multirow{2}{*}{$\begin{array}{c}2000-2003 \\
(3)\end{array}$} \\
\hline & (1) & (2) & & (1) & (2) & \\
\hline CONSTANT & $\begin{array}{c}0.527 \\
(0.618)\end{array}$ & $\begin{array}{c}0.525 \\
(0.617)\end{array}$ & $\begin{array}{c}0.244 \\
(0.878)\end{array}$ & $\begin{array}{c}0.798^{\star * *} \\
(0.259)\end{array}$ & $\begin{array}{c}0.799^{\star * \star} \\
(0.259)\end{array}$ & $\begin{array}{c}0.966^{\star * *} \\
(0.315)\end{array}$ \\
\hline MAIN & $\begin{array}{c}0.359^{\star * *} \\
(0.090)\end{array}$ & $\begin{array}{c}0.351^{* * *} \\
(0.090)\end{array}$ & $\begin{array}{l}0.283^{\star *} \\
(0.131)\end{array}$ & $\begin{array}{c}0.157^{\star * *} \\
(0.048)\end{array}$ & $\begin{array}{c}0.157^{\star \star \star} \\
(0.048)\end{array}$ & $\begin{array}{l}-0.006 \\
(0.061)\end{array}$ \\
\hline UNEMPLOY & $\begin{array}{l}-0.110 \\
(0.104)\end{array}$ & $\begin{array}{l}-0.107 \\
(0.104)\end{array}$ & $\begin{array}{l}-0.137 \\
(0.139)\end{array}$ & $\begin{array}{c}-0.100^{* * *} \\
(0.035)\end{array}$ & $\begin{array}{c}-0.101^{* * *} \\
(0.035)\end{array}$ & $\begin{array}{l}-0.042 \\
(0.047)\end{array}$ \\
\hline LAGE & $\begin{array}{l}-0.043 \\
(0.164)\end{array}$ & $\begin{array}{l}-0.040 \\
(0.163)\end{array}$ & $\begin{array}{c}0.063 \\
(0.229)\end{array}$ & $\begin{array}{c}-0.149^{\star *} \\
(0.068)\end{array}$ & $\begin{array}{c}-0.150^{\star *} \\
(0.068)\end{array}$ & $\begin{array}{c}-0.228^{\star \star *} \\
(0.081)\end{array}$ \\
\hline GENDER & $\begin{array}{c}0.067 \\
(0.083)\end{array}$ & $\begin{array}{c}0.071 \\
(0.083)\end{array}$ & $\begin{array}{c}0.106 \\
(0.114)\end{array}$ & $\begin{array}{l}-0.029 \\
(0.034)\end{array}$ & $\begin{array}{l}-0.029 \\
(0.034)\end{array}$ & $\begin{array}{c}0.030 \\
(0.043)\end{array}$ \\
\hline QUAL & $\begin{array}{c}0.089 \\
(0.078)\end{array}$ & $\begin{array}{c}0.088 \\
(0.078)\end{array}$ & $\begin{array}{c}0.157 \\
(0.110)\end{array}$ & $\begin{array}{l}0.078^{\star *} \\
(0.031)\end{array}$ & $\begin{array}{l}0.078^{\star *} \\
(0.031)\end{array}$ & $\begin{array}{l}0.091^{* *} \\
(0.038)\end{array}$ \\
\hline$R \& D$ & $\begin{array}{l}-0.080 \\
(0.093)\end{array}$ & $\begin{array}{l}-0.075 \\
(0.093)\end{array}$ & $\begin{array}{c}-0.294^{* *} \\
(0.127)\end{array}$ & $\begin{array}{c}0.032 \\
(0.040)\end{array}$ & $\begin{array}{c}0.032 \\
(0.040)\end{array}$ & $\begin{array}{l}-0.009 \\
(0.044)\end{array}$ \\
\hline NP & $\begin{array}{l}-0.120 \\
(0.099)\end{array}$ & $\begin{array}{l}-0.121 \\
(0.099)\end{array}$ & $\begin{array}{c}0.461^{* * *} \\
(0.170)\end{array}$ & $\begin{array}{l}0.091^{* *} \\
(0.043)\end{array}$ & $\begin{array}{l}0.092^{* *} \\
(0.043)\end{array}$ & $\begin{array}{l}0.142^{* * *} \\
(0.055)\end{array}$ \\
\hline MP & $\begin{array}{c}0.076 \\
(0.077)\end{array}$ & $\begin{array}{l}0.075 \\
(0.077)\end{array}$ & $\begin{array}{c}0.155 \\
(0.105)\end{array}$ & $\begin{array}{c}0.093^{* * *} \\
(0.031)\end{array}$ & $\begin{array}{c}0.093^{* \star *} \\
(0.031)\end{array}$ & $\begin{array}{c}0.018 \\
(0.035)\end{array}$ \\
\hline РСOMP & $\begin{array}{l}-0.066 \\
(0.071)\end{array}$ & $\begin{array}{l}-0.068 \\
(0.071)\end{array}$ & $\begin{array}{l}-0.009 \\
(0.097)\end{array}$ & $\begin{array}{l}-0.012 \\
(0.028)\end{array}$ & $\begin{array}{l}-0.012 \\
(0.029)\end{array}$ & $\begin{array}{c}0.051 \\
(0.034)\end{array}$ \\
\hline NPCOMP & $\begin{array}{c}0.038 \\
(0.072)\end{array}$ & $\begin{array}{c}0.037 \\
(0.072)\end{array}$ & $\begin{array}{l}0.184^{*} \\
(0.097)\end{array}$ & $\begin{array}{l}-0.006 \\
(0.029)\end{array}$ & $\begin{array}{l}-0.006 \\
(0.029)\end{array}$ & $\begin{array}{l}0.094^{\star \star \star} \\
(0.035)\end{array}$ \\
\hline LCAP & $\begin{array}{l}-0.016 \\
(0.020)\end{array}$ & $\begin{array}{l}-0.017 \\
(0.020)\end{array}$ & $\begin{array}{c}0.001 \\
(0.027)\end{array}$ & $\begin{array}{l}0.015^{\star} \\
(0.008)\end{array}$ & $\begin{array}{l}0.015^{*} \\
(0.008)\end{array}$ & $\begin{array}{c}0.006 \\
(0.008)\end{array}$ \\
\hline$A G$ & $\begin{array}{c}0.106 \\
(0.115)\end{array}$ & $\begin{array}{c}0.112 \\
(0.115)\end{array}$ & $\begin{array}{c}-0.370^{\star *} \\
(0.150)\end{array}$ & $\begin{array}{c}0.536^{* \star *} \\
(0.060)\end{array}$ & $\begin{array}{c}0.536^{\star \star \star} \\
(0.060)\end{array}$ & $\begin{array}{l}0.317^{\star \star \star} \\
(0.060)\end{array}$ \\
\hline GMBH & $\begin{array}{l}-0.159^{*} \\
(0.087)\end{array}$ & $\begin{array}{l}-0.156^{\star} \\
(0.087)\end{array}$ & $\begin{array}{c}-0.326^{* * *} \\
(0.117)\end{array}$ & $\begin{array}{c}0.120^{* \star \star} \\
(0.034)\end{array}$ & $\begin{array}{c}0.120^{\star \star \star} \\
(0.034)\end{array}$ & $\begin{array}{c}0.129^{* \star \star} \\
(0.040)\end{array}$ \\
\hline OTHER & $\begin{array}{l}-0.010 \\
(0.123)\end{array}$ & $\begin{array}{l}-0.011 \\
(0.123)\end{array}$ & $\begin{array}{l}-0.056 \\
(0.248)\end{array}$ & $\begin{array}{c}0.001 \\
(0.044)\end{array}$ & $\begin{array}{c}0.000 \\
(0.044)\end{array}$ & $\begin{array}{c}0.055 \\
(0.098)\end{array}$ \\
\hline LSIZE & $\begin{array}{l}0.175^{\star} \\
(0.106)\end{array}$ & $\begin{array}{c}0.173 \\
(0.106)\end{array}$ & $\begin{array}{l}-0.054 \\
(0.100)\end{array}$ & $\begin{array}{c}-0.357^{* * *} \\
(0.046)\end{array}$ & $\begin{array}{c}-0.358^{* * *} \\
(0.047)\end{array}$ & $\begin{array}{c}-0.222^{* * *} \\
(0.049)\end{array}$ \\
\hline IND_1 & $\begin{array}{c}-0.377^{\star \star} \\
(0.163)\end{array}$ & $\begin{array}{c}-0.383^{\star *} \\
(0.163)\end{array}$ & $\begin{array}{l}-0.101 \\
(0.233)\end{array}$ & $\begin{array}{c}-0.201^{\star \star *} \\
(0.067)\end{array}$ & $\begin{array}{c}-0.201^{\star \star *} \\
(0.067)\end{array}$ & $\begin{array}{l}-0.087 \\
(0.083)\end{array}$ \\
\hline IND_2 & $\begin{array}{c}0.178 \\
(0.134)\end{array}$ & $\begin{array}{c}0.175 \\
(0.134)\end{array}$ & $\begin{array}{l}-0.037 \\
(0.186)\end{array}$ & $\begin{array}{c}-0.243^{* \star *} \\
(0.052)\end{array}$ & $\begin{array}{c}-0.242^{\star * *} \\
(0.052)\end{array}$ & $\begin{array}{c}-0.145^{\star \star} \\
(0.060)\end{array}$ \\
\hline IND_3 & $\begin{array}{c}-0.325^{\star *} \\
(0.130)\end{array}$ & $\begin{array}{c}-0.324^{* *} \\
(0.130)\end{array}$ & $\begin{array}{c}0.029 \\
(0.182)\end{array}$ & $\begin{array}{c}-0.162^{\star \star *} \\
(0.051)\end{array}$ & $\begin{array}{c}-0.161^{\star \star *} \\
(0.051)\end{array}$ & $\begin{array}{l}-0.057 \\
(0.061)\end{array}$ \\
\hline $\begin{array}{l}\text { DEBT_CONST_INSAMP03 } \\
\text { DEBT_CONST_OUTSAMP03 }\end{array}$ & $\begin{array}{c}-0.048^{\star \star \star} \\
(0.017) \\
-0.093^{\star \star \star} \\
(0.020)\end{array}$ & & & $\begin{array}{l}0.007 \\
(0.006) \\
0.007 \\
(0.009)\end{array}$ & & \\
\hline $\begin{array}{l}\text { DEBT_CONST_INSAMP06 } \\
\text { DEBT_CONST_OUTSAMP06 }\end{array}$ & & $\begin{array}{c}-0.060^{* \star *} \\
(0.021) \\
-0.074^{\star \star *} \\
(0.016) \\
\end{array}$ & $\begin{array}{c}-0.049^{* *} \\
(0.023) \\
-0.061^{* *} \\
(0.028)\end{array}$ & & $\begin{array}{l}0.011 \\
(0.007) \\
0.004 \\
(0.007)\end{array}$ & $\begin{array}{c}-0.010 \\
(0.009) \\
0.001 \\
(0.012)\end{array}$ \\
\hline $\begin{array}{l}\mathrm{N} \\
\mathrm{R}^{2} \\
\mathrm{~F} \\
\text { Pseudo } \mathrm{R}^{2} \\
\text { Wald chi }\end{array}$ & $\begin{array}{c}0.077 \\
132.89^{\star \star *} \\
\end{array}$ & $\begin{array}{c}0.075 \\
131.59^{\star * *} \\
\end{array}$ & $\begin{array}{c}0.050 \\
49.70^{\star \star \star} \\
\end{array}$ & $\begin{array}{c}1589 \\
0.144 \\
8.32^{\star \star *}\end{array}$ & $\begin{array}{c}1589 \\
0.144 \\
8.33^{\star \star *}\end{array}$ & $\begin{array}{c}911 \\
0.091 \\
4.06^{\star \star *}\end{array}$ \\
\hline $\begin{array}{l}\text { Wald test on equality of } \\
\text { coefficients of interaction terms }\end{array}$ & $3.07^{\star}$ & 0.28 & 0.11 & 0.00 & 0.43 & 0.56 \\
\hline
\end{tabular}

Notes: see table 3 for the variable definitions; heteroskedasticity-robust standard errors (White procedure) are in brackets under the coefficients; $* * *, * *, *$ denotes statistical significance at the $1 \%, 5 \%$ and $10 \%$ test level, respectively. 
Table A.4: Estimates include interaction terms for VC_CONST

\begin{tabular}{|c|c|c|c|c|c|c|}
\hline \multirow{3}{*}{$\begin{array}{l}\text { Dependent variable } \\
\text { Period } \\
\text { Explanatory variables } \\
\end{array}$} & \multicolumn{3}{|c|}{ BREAK } & \multicolumn{3}{|c|}{ GROWTH } \\
\hline & \multicolumn{2}{|c|}{2000} & \multirow{2}{*}{$\begin{array}{c}2003 \\
(3) \\
\end{array}$} & \multicolumn{2}{|c|}{$1996 / 97-2000$} & \multirow{2}{*}{$\begin{array}{c}2000-2003 \\
(3)\end{array}$} \\
\hline & (1) & (2) & & (1) & (2) & \\
\hline CONSTANT & $\begin{array}{c}0.344 \\
(0.616)\end{array}$ & $\begin{array}{c}0.346 \\
(0.619)\end{array}$ & $\begin{array}{c}0.369 \\
(0.882)\end{array}$ & $\begin{array}{c}0.829^{* \star *} \\
(0.259)\end{array}$ & $\begin{array}{c}0.828^{\star \star \star} \\
(0.259)\end{array}$ & $\begin{array}{l}1.010^{* \star *} \\
(0.316)\end{array}$ \\
\hline MAIN & $\begin{array}{c}0.317^{\star \star *} \\
(0.090)\end{array}$ & $\begin{array}{c}0.320^{\star * \star} \\
(0.091)\end{array}$ & $\begin{array}{l}0.285^{\star *} \\
(0.130)\end{array}$ & $\begin{array}{c}0.158^{\star \star \star} \\
(0.048)\end{array}$ & $\begin{array}{c}0.158^{* * *} \\
(0.048)\end{array}$ & $\begin{array}{l}-0.009 \\
(0.060)\end{array}$ \\
\hline UNEMPLOY & $\begin{array}{l}-0.113 \\
(0.103)\end{array}$ & $\begin{array}{l}-0.117 \\
(0.103)\end{array}$ & $\begin{array}{l}-0.149 \\
(0.138)\end{array}$ & $\begin{array}{c}-0.098^{* * *} \\
(0.035)\end{array}$ & $\begin{array}{c}-0.098^{\star * \star} \\
(0.035)\end{array}$ & $\begin{array}{l}-0.043 \\
(0.046)\end{array}$ \\
\hline LAGE & $\begin{array}{c}0.051 \\
(0.162)\end{array}$ & $\begin{array}{c}0.054 \\
(0.162)\end{array}$ & $\begin{array}{c}0.070 \\
(0.230)\end{array}$ & $\begin{array}{c}-0.159^{\star \star} \\
(0.067)\end{array}$ & $\begin{array}{c}-0.159^{\star \star} \\
(0.067)\end{array}$ & $\begin{array}{c}-0.232^{\star \star \star} \\
(0.081)\end{array}$ \\
\hline GENDER & $\begin{array}{c}0.066 \\
(0.084)\end{array}$ & $\begin{array}{c}0.063 \\
(0.083)\end{array}$ & $\begin{array}{c}0.126 \\
(0.114)\end{array}$ & $\begin{array}{l}-0.027 \\
(0.034)\end{array}$ & $\begin{array}{l}-0.027 \\
(0.034)\end{array}$ & $\begin{array}{c}0.035 \\
(0.043)\end{array}$ \\
\hline QUAL & $\begin{array}{c}0.127 \\
(0.077)\end{array}$ & $\begin{array}{l}0.137^{\star} \\
(0.077)\end{array}$ & $\begin{array}{c}0.180 \\
(0.111)\end{array}$ & $\begin{array}{l}0.075^{* \star} \\
(0.031)\end{array}$ & $\begin{array}{l}0.076^{* \star} \\
(0.031)\end{array}$ & $\begin{array}{l}0.095^{\star *} \\
(0.038)\end{array}$ \\
\hline$R \& D$ & $\begin{array}{l}-0.079 \\
(0.094)\end{array}$ & $\begin{array}{l}-0.071 \\
(0.094)\end{array}$ & $\begin{array}{c}-0.299^{* *} \\
(0.128)\end{array}$ & $\begin{array}{c}0.033 \\
(0.041)\end{array}$ & $\begin{array}{c}0.033 \\
(0.041)\end{array}$ & $\begin{array}{l}-0.006 \\
(0.043)\end{array}$ \\
\hline NP & $\begin{array}{l}-0.138 \\
(0.099)\end{array}$ & $\begin{array}{l}-0.132 \\
(0.099)\end{array}$ & $\begin{array}{c}0.458^{* * *} \\
(0.170)\end{array}$ & $\begin{array}{l}0.095^{* *} \\
(0.044)\end{array}$ & $\begin{array}{l}0.095^{* *} \\
(0.044)\end{array}$ & $\begin{array}{l}0.138^{\star *} \\
(0.055)\end{array}$ \\
\hline MP & $\begin{array}{c}0.072 \\
(0.077)\end{array}$ & $\begin{array}{c}0.057 \\
(0.077)\end{array}$ & $\begin{array}{c}0.139 \\
(0.106)\end{array}$ & $\begin{array}{c}0.095^{\star \star *} \\
(0.031)\end{array}$ & $\begin{array}{c}0.094^{\star \star \star} \\
(0.031)\end{array}$ & $\begin{array}{c}0.016 \\
(0.035)\end{array}$ \\
\hline РСOMP & $\begin{array}{l}-0.074 \\
(0.070)\end{array}$ & $\begin{array}{l}-0.071 \\
(0.071)\end{array}$ & $\begin{array}{l}-0.037 \\
(0.096)\end{array}$ & $\begin{array}{l}-0.010 \\
(0.029)\end{array}$ & $\begin{array}{l}-0.010 \\
(0.029)\end{array}$ & $\begin{array}{c}0.048 \\
(0.035)\end{array}$ \\
\hline NPCOMP & $\begin{array}{c}0.038 \\
(0.072)\end{array}$ & $\begin{array}{c}0.030 \\
(0.072)\end{array}$ & $\begin{array}{l}0.183^{*} \\
(0.097)\end{array}$ & $\begin{array}{l}-0.006 \\
(0.029)\end{array}$ & $\begin{array}{l}-0.006 \\
(0.029)\end{array}$ & $\begin{array}{c}0.093^{* * *} \\
(0.035)\end{array}$ \\
\hline LCAP & $\begin{array}{l}-0.017 \\
(0.020)\end{array}$ & $\begin{array}{l}-0.017 \\
(0.020)\end{array}$ & $\begin{array}{c}0.000 \\
(0.027)\end{array}$ & $\begin{array}{l}0.015^{\star} \\
(0.008)\end{array}$ & $\begin{array}{l}0.015^{\star} \\
(0.008)\end{array}$ & $\begin{array}{c}0.006 \\
(0.008)\end{array}$ \\
\hline$A G$ & $\begin{array}{c}0.091 \\
(0.114)\end{array}$ & $\begin{array}{c}0.098 \\
(0.114)\end{array}$ & $\begin{array}{c}-0.342^{\star *} \\
(0.151)\end{array}$ & $\begin{array}{c}0.539^{\star * *} \\
(0.060)\end{array}$ & $\begin{array}{c}0.540^{\star \star *} \\
(0.060)\end{array}$ & $\begin{array}{c}0.325^{\star * \star} \\
(0.060)\end{array}$ \\
\hline GMBH & $\begin{array}{l}-0.163^{*} \\
(0.087)\end{array}$ & $\begin{array}{l}-0.170^{*} \\
(0.087)\end{array}$ & $\begin{array}{c}-0.345^{* \star *} \\
(0.116)\end{array}$ & $\begin{array}{c}0.122^{* * *} \\
(0.034)\end{array}$ & $\begin{array}{c}0.121^{* * *} \\
(0.034)\end{array}$ & $\begin{array}{c}0.125^{\star * *} \\
(0.040)\end{array}$ \\
\hline OTHER & $\begin{array}{l}-0.039 \\
(0.123)\end{array}$ & $\begin{array}{l}-0.040 \\
(0.123)\end{array}$ & $\begin{array}{c}0.014 \\
(0.252)\end{array}$ & $\begin{array}{c}0.001 \\
(0.044)\end{array}$ & $\begin{array}{c}0.000 \\
(0.044)\end{array}$ & $\begin{array}{c}0.069 \\
(0.100)\end{array}$ \\
\hline LSIZE & $\begin{array}{l}0.175^{*} \\
(0.106)\end{array}$ & $\begin{array}{c}0.166 \\
(0.105)\end{array}$ & $\begin{array}{l}-0.065 \\
(0.101)\end{array}$ & $\begin{array}{c}-0.356^{* * *} \\
(0.046)\end{array}$ & $\begin{array}{c}-0.356^{\star * \star} \\
(0.046)\end{array}$ & $\begin{array}{c}-0.224^{\star * *} \\
(0.049)\end{array}$ \\
\hline IND_1 & $\begin{array}{l}-0.373^{\star *} \\
(0.164)\end{array}$ & $\begin{array}{c}-0.378^{* *} \\
(0.163)\end{array}$ & $\begin{array}{l}-0.118 \\
(0.235)\end{array}$ & $\begin{array}{c}-0.199^{* * *} \\
(0.067)\end{array}$ & $\begin{array}{c}-0.200^{* * \star} \\
(0.067)\end{array}$ & $\begin{array}{l}-0.089 \\
(0.083)\end{array}$ \\
\hline IND_2 & $\begin{array}{c}0.219 \\
(0.135)\end{array}$ & $\begin{array}{c}0.208 \\
(0.134)\end{array}$ & $\begin{array}{l}-0.050 \\
(0.189)\end{array}$ & $\begin{array}{c}-0.247^{* * *} \\
(0.052)\end{array}$ & $\begin{array}{c}-0.247^{* * *} \\
(0.052)\end{array}$ & $\begin{array}{l}-0.146^{* *} \\
(0.060)\end{array}$ \\
\hline IND_3 & $\begin{array}{l}-0.311^{\star *} \\
(0.131)\end{array}$ & $\begin{array}{c}-0.298^{* *} \\
(0.130)\end{array}$ & $\begin{array}{c}0.025 \\
(0.185)\end{array}$ & $\begin{array}{c}-0.160^{* * *} \\
(0.051)\end{array}$ & $\begin{array}{c}-0.159^{* * *} \\
(0.051)\end{array}$ & $\begin{array}{l}-0.054 \\
(0.060)\end{array}$ \\
\hline $\begin{array}{l}\text { VC_CONST_INSAMP03 } \\
\text { VC_CONST_OUTSAMP03 }\end{array}$ & $\begin{array}{c}-0.045 \\
(0.034) \\
-0.171^{* \star *} \\
(0.034)\end{array}$ & & & $\begin{array}{l}0.006 \\
(0.013) \\
-0.003 \\
(0.015)\end{array}$ & & \\
\hline $\begin{array}{l}\text { VC_CONST_INSAMP06 } \\
\text { VC_CONST_OUTSAMP06 }\end{array}$ & & $\begin{array}{c}-0.025 \\
(0.041) \\
-0.139^{\star \star \star} \\
(0.031)\end{array}$ & \begin{tabular}{|c|}
-0.038 \\
$(0.048)$ \\
$-0.169^{\star \star \star}$ \\
$(0.050)$ \\
\end{tabular} & & $\begin{array}{l}0.009 \\
(0.014) \\
-0.001 \\
(0.014)\end{array}$ & $\begin{array}{l}-0.011 \\
(0.018) \\
-0.033 \\
(0.024)\end{array}$ \\
\hline $\begin{array}{l}\mathrm{N} \\
\mathrm{R}^{2} \\
\mathrm{~F} \\
\text { Pseudo } \mathrm{R}^{2} \\
\text { Wald chi }\end{array}$ & $\begin{array}{c}0.075 \\
132.02^{\star * *} \\
\end{array}$ & $\begin{array}{r}0.073 \\
129.88^{\star \star *} \\
\end{array}$ & $\begin{array}{c}0.054 \\
53.23^{\star \star \star} \\
\end{array}$ & $\begin{array}{c}1589 \\
0.143 \\
8.28^{* \star *}\end{array}$ & $\begin{array}{c}1589 \\
0.143 \\
8.29^{\star \star \star}\end{array}$ & $\begin{array}{c}911 \\
0.093 \\
4.23^{\star \star \star}\end{array}$ \\
\hline $\begin{array}{l}\text { Wald test on equality of } \\
\text { coefficients of interaction terms }\end{array}$ & $13.09^{\star \star \star}$ & $8.91^{\star \star \star}$ & $6.67^{\star \star \star}$ & 0.34 & 0.48 & 1.05 \\
\hline
\end{tabular}

Notes: see table 3 for the variable definitions; heteroskedasticity-robust standard errors (White procedure) are in brackets under the coefficients; ***, **, * denotes statistical significance at the $1 \%, 5 \%$ and $10 \%$ test level, respectively. 
Table A.5: Profit break-even of start-ups; probit estimates (unweighted)

\begin{tabular}{|c|c|c|c|c|c|c|c|c|c|c|c|c|c|c|c|}
\hline \multirow{2}{*}{\begin{tabular}{|l|} 
Period \\
Explanatory variables \\
\end{tabular}} & \multicolumn{5}{|c|}{ BREAK 2000} & \multicolumn{5}{|c|}{ BREAK 2003} & \multicolumn{5}{|c|}{ BREAK 2006} \\
\hline & (1) & (2) & (3) & (4) & (5) & (1) & (2) & (3) & (4) & (5) & (1) & (2) & (3) & (4) & (5) \\
\hline \multirow[t]{2}{*}{ CONSTANT } & 0.521 & 0.682 & 0.602 & 0.570 & 0.388 & 0.225 & 0.386 & 0.427 & 0.482 & 0.439 & $3.306^{\star * *}$ & $3.411^{\star * \star}$ & $3.419^{\star \star \star *}$ & $3.568^{\star * *}$ & $2.962^{\star \star \star}$ \\
\hline & $(0.617)$ & $(0.623)$ & $(0.619)$ & $(0.622)$ & $(0.617)$ & $(0.877)$ & $(0.877)$ & $(0.875)$ & $(0.874)$ & $(0.877)$ & $(1.170)$ & (1.183) & (1.179) & $(1.165)$ & $(1.146)$ \\
\hline \multirow[t]{2}{*}{ MAIN } & $0.351^{\text {***}}$ & $0.345^{\star \star \star}$ & $0.354^{\star * *}$ & $0.338^{\star \star *}$ & $0.323^{\star \star *}$ & $0.285^{\star \star}$ & $0.298^{\star *}$ & $0.285^{\star \star}$ & $0.274^{* *}$ & $0.276^{* *}$ & -0.161 & -0.145 & -0.172 & -0.180 & -0.203 \\
\hline & $(0.090)$ & $(0.090)$ & $(0.090)$ & $(0.090)$ & $(0.090)$ & $(0.131)$ & $(0.131)$ & $(0.131)$ & $(0.130)$ & $(0.130)$ & $(0.195)$ & (0.195) & $(0.194)$ & $(0.194)$ & (0.193) \\
\hline \multirow[t]{2}{*}{ UNEMPLOY } & -0.105 & -0.124 & -0.105 & -0.112 & -0.109 & -0.138 & -0.145 & -0.139 & -0.151 & -0.142 & -0.055 & -0.071 & -0.075 & -0.070 & -0.130 \\
\hline & $(0.104)$ & $(0.103)$ & $(0.103)$ & $(0.103)$ & $(0.103)$ & $(0.139)$ & $(0.139)$ & $(0.139)$ & $(0.140)$ & $(0.138)$ & $(0.180)$ & $(0.179)$ & $(0.178)$ & $(0.178)$ & $(0.174)$ \\
\hline \multirow[t]{2}{*}{ LAGE } & -0.037 & -0.017 & -0.004 & 0.010 & 0.045 & 0.068 & 0.060 & 0.067 & 0.073 & 0.059 & $-0.692^{* *}$ & $-0.646^{\star *}$ & $-0.660^{\star *}$ & $-0.673^{\star *}$ & $-0.579^{*}$ \\
\hline & $(0.163)$ & $(0.163)$ & $(0.163)$ & $(0.163)$ & $(0.162)$ & $(0.229)$ & $(0.229)$ & $(0.229)$ & $(0.229)$ & $(0.229)$ & $(0.307)$ & $(0.307)$ & $(0.306)$ & $(0.301)$ & $(0.298)$ \\
\hline \multirow[t]{2}{*}{ GENDER } & 0.071 & 0.067 & 0.075 & 0.059 & 0.052 & 0.105 & 0.099 & 0.100 & 0.105 & 0.107 & 0.214 & 0.205 & 0.208 & 0.213 & 0.188 \\
\hline & $(0.083)$ & $(0.083)$ & $(0.083)$ & $(0.083)$ & $(0.083)$ & $(0.114)$ & $(0.114)$ & $(0.114)$ & $(0.114)$ & $(0.113)$ & $(0.150)$ & $(0.149)$ & $(0.148)$ & $(0.150)$ & $(0.148)$ \\
\hline \multirow[t]{2}{*}{ QUAL } & 0.088 & 0.097 & 0.088 & 0.096 & 0.125 & 0.156 & 0.165 & 0.153 & 0.165 & 0.181 & 0.078 & 0.065 & 0.069 & 0.109 & 0.091 \\
\hline & $(0.078)$ & $(0.077)$ & $(0.077)$ & $(0.077)$ & $(0.077)$ & $(0.110)$ & $(0.110)$ & $(0.110)$ & $(0.110)$ & $(0.110)$ & $(0.141)$ & $(0.142)$ & $(0.141)$ & $(0.140)$ & $(0.139)$ \\
\hline \multirow[t]{2}{*}{$R \& D$} & -0.075 & -0.091 & -0.079 & -0.082 & -0.062 & $-0.296^{\star *}$ & $-0.304^{* *}$ & $-0.315^{\star *}$ & $-0.286^{* *}$ & $-0.307^{\star *}$ & -0.237 & -0.254 & -0.245 & -0.242 & -0.272 \\
\hline & $(0.093)$ & $(0.093)$ & $(0.093)$ & $(0.093)$ & $(0.094)$ & $(0.127)$ & $(0.127)$ & $(0.128)$ & $(0.127)$ & $(0.127)$ & $(0.176)$ & $(0.175)$ & $(0.175)$ & $(0.176)$ & $(0.174)$ \\
\hline \multirow[t]{2}{*}{ NP } & -0.121 & -0.126 & -0.125 & -0.136 & -0.140 & $0.465^{\star \star \star}$ & $0.464^{\star \star \star}$ & $0.471^{* * *}$ & $0.460^{* \star *}$ & $0.468^{\star * *}$ & -0.106 & -0.129 & -0.127 & -0.103 & -0.127 \\
\hline & $(0.099)$ & (0.099) & $(0.099)$ & $(0.098)$ & $(0.099)$ & $(0.170)$ & $(0.170)$ & $(0.170)$ & $(0.169)$ & $(0.169)$ & $(0.201)$ & $(0.198)$ & $(0.196)$ & $(0.202)$ & $(0.197)$ \\
\hline \multirow[t]{2}{*}{ MP } & 0.076 & 0.071 & 0.074 & 0.071 & 0.065 & 0.155 & 0.144 & 0.156 & 0.151 & 0.147 & 0.001 & 0.002 & -0.019 & -0.001 & -0.018 \\
\hline & $(0.077)$ & $(0.077)$ & $(0.077)$ & $(0.077)$ & $(0.077)$ & $(0.105)$ & $(0.104)$ & $(0.105)$ & $(0.105)$ & $(0.105)$ & $(0.136)$ & $(0.136)$ & $(0.135)$ & $(0.135)$ & $(0.133)$ \\
\hline \multirow[t]{2}{*}{ PCOMP } & -0.069 & -0.071 & -0.067 & -0.087 & -0.072 & -0.010 & -0.018 & -0.015 & -0.017 & -0.035 & -0.038 & -0.001 & -0.038 & -0.063 & -0.025 \\
\hline & $(0.071)$ & $(0.070)$ & $(0.070)$ & $(0.070)$ & $(0.070)$ & $(0.097)$ & $(0.097)$ & $(0.097)$ & $(0.097)$ & $(0.096)$ & $(0.123)$ & $(0.123)$ & $(0.123)$ & $(0.123)$ & $(0.123)$ \\
\hline \multirow[t]{2}{*}{ NPCOMP } & 0.038 & 0.039 & 0.031 & 0.044 & 0.037 & $0.184^{*}$ & $0.184^{*}$ & $0.184^{*}$ & $0.180^{*}$ & $0.187^{\star}$ & $0.465^{\star \star *}$ & $0.450^{* * *}$ & $0.474^{* * *}$ & $0.448^{* * *}$ & $0.440^{\star * *}$ \\
\hline & $(0.072)$ & $(0.072)$ & $(0.072)$ & $(0.072)$ & $(0.072)$ & $(0.097)$ & $(0.097)$ & $(0.097)$ & $(0.097)$ & $(0.096)$ & $(0.129)$ & $(0.129)$ & $(0.129)$ & $(0.129)$ & $(0.128)$ \\
\hline \multirow[t]{2}{*}{ LCAP } & -0.017 & -0.016 & -0.014 & -0.020 & -0.017 & 0.001 & 0.003 & 0.001 & -0.002 & -0.001 & 0.007 & 0.011 & 0.011 & 0.007 & 0.018 \\
\hline & $(0.020)$ & $(0.020)$ & $(0.020)$ & $(0.020)$ & $(0.020)$ & $(0.027)$ & $(0.027)$ & $(0.027)$ & $(0.027)$ & $(0.027)$ & $(0.036)$ & $(0.036)$ & $(0.036)$ & $(0.036)$ & $(0.036)$ \\
\hline \multirow[t]{2}{*}{$A G$} & 0.112 & 0.110 & 0.115 & 0.087 & 0.088 & $-0.373^{\star *}$ & $-0.363^{\star *}$ & $-0.367^{\star \star}$ & $-0.380^{* *}$ & $-0.352^{\star *}$ & -0.254 & -0.230 & -0.259 & -0.247 & -0.224 \\
\hline & $(0.115)$ & $(0.114)$ & $(0.115)$ & $(0.114)$ & $(0.114)$ & $(0.150)$ & $(0.150)$ & $(0.150)$ & $(0.149)$ & $(0.150)$ & $(0.199)$ & $(0.199)$ & $(0.198)$ & $(0.197)$ & $(0.196)$ \\
\hline \multirow[t]{2}{*}{ GMBH } & $-0.156^{*}$ & $-0.152^{*}$ & $-0.160^{*}$ & $-0.171^{* *}$ & $-0.167^{\star}$ & $-0.323^{* * *}$ & $-0.325^{\star * *}$ & $-0.330^{* * *}$ & $-0.319^{* * *}$ & $-0.321^{* * *}$ & $-0.262^{*}$ & $-0.279^{\star}$ & $-0.285^{\star}$ & $-0.259^{*}$ & $-0.300^{* *}$ \\
\hline & $(0.087)$ & $(0.087)$ & $(0.087)$ & $(0.087)$ & $(0.087)$ & $(0.116)$ & $(0.116)$ & $(0.116)$ & $(0.116)$ & $(0.116)$ & $(0.153)$ & $(0.151)$ & $(0.151)$ & $(0.154)$ & $(0.150)$ \\
\hline \multirow[t]{2}{*}{ OTHER } & -0.009 & -0.018 & -0.007 & -0.008 & -0.020 & -0.059 & -0.042 & -0.068 & -0.045 & -0.028 & -0.009 & -0.011 & -0.036 & -0.000 & -0.007 \\
\hline & $(0.123)$ & $(0.123)$ & $(0.123)$ & $(0.123)$ & $(0.123)$ & $(0.247)$ & $(0.247)$ & $(0.247)$ & $(0.246)$ & $(0.247)$ & $(0.358)$ & $(0.353)$ & $(0.350)$ & $(0.356)$ & $(0.338)$ \\
\hline \multirow[t]{2}{*}{ LSIZE } & 0.174 & 0.160 & 0.176 & 0.170 & 0.166 & -0.053 & -0.059 & -0.053 & -0.057 & -0.062 & 0.064 & 0.062 & 0.064 & 0.055 & 0.058 \\
\hline & $(0.106)$ & $(0.106)$ & $(0.107)$ & $(0.104)$ & $(0.105)$ & $(0.100)$ & $(0.100)$ & $(0.100)$ & $(0.099)$ & $(0.101)$ & $(0.124)$ & (0.122) & $(0.124)$ & $(0.124)$ & $(0.121)$ \\
\hline \multirow[t]{2}{*}{ IND_1 } & $-0.385^{\star *}$ & $-0.399^{* *}$ & $-0.384^{* *}$ & $-0.387^{* *}$ & $-0.366^{* *}$ & -0.101 & -0.077 & -0.083 & -0.159 & -0.095 & 0.158 & 0.192 & 0.217 & 0.104 & 0.178 \\
\hline & $(0.163)$ & $(0.163)$ & $(0.162)$ & $(0.163)$ & $(0.164)$ & $(0.233)$ & $(0.234)$ & $(0.233)$ & $(0.233)$ & $(0.234)$ & (0.298) & $(0.302)$ & $(0.298)$ & $(0.295)$ & $(0.298)$ \\
\hline \multirow[t]{2}{*}{ IND_2 } & 0.172 & 0.162 & 0.171 & 0.202 & 0.221 & -0.040 & -0.019 & -0.022 & -0.074 & -0.032 & 0.017 & 0.023 & 0.074 & 0.015 & 0.100 \\
\hline & $(0.134)$ & $(0.135)$ & $(0.135)$ & $(0.134)$ & $(0.134)$ & $(0.186)$ & $(0.186)$ & $(0.186)$ & $(0.188)$ & $(0.188)$ & $(0.225)$ & $(0.228)$ & $(0.223)$ & $(0.223)$ & $(0.224)$ \\
\hline
\end{tabular}




\begin{tabular}{|c|c|c|c|c|c|c|c|c|c|c|c|c|c|c|c|}
\hline IND_3 & $\begin{array}{c}-0.326^{\star \star} \\
(0.130)\end{array}$ & $\begin{array}{c}-0.338^{\star * \star} \\
(0.130)\end{array}$ & $\begin{array}{c}-0.338^{\star * *} \\
(0.131)\end{array}$ & $\begin{array}{c}-0.319^{\star *} \\
(0.130)\end{array}$ & $\begin{array}{c}-0.304^{\star *} \\
(0.131)\end{array}$ & $\begin{array}{c}0.026 \\
(0.183)\end{array}$ & $\begin{array}{c}0.039 \\
(0.184)\end{array}$ & $\begin{array}{c}0.026 \\
(0.183)\end{array}$ & $\begin{array}{c}-0.020 \\
(0.183)\end{array}$ & $\begin{array}{c}0.008 \\
(0.184)\end{array}$ & $\begin{array}{c}-0.067 \\
(0.230)\end{array}$ & $\begin{array}{l}-0.050 \\
(0.232)\end{array}$ & $\begin{array}{l}-0.038 \\
(0.229)\end{array}$ & $\begin{array}{l}-0.104 \\
(0.228)\end{array}$ & $\begin{array}{l}-0.059 \\
(0.229)\end{array}$ \\
\hline DEBT_CONST & $\begin{array}{c}-0.069^{* * *} \\
(0.013)\end{array}$ & & & & & $\begin{array}{c}-0.054^{\star \star *} \\
(0.018)\end{array}$ & & & & & $\begin{array}{c}-0.091^{* * *} \\
(0.023)\end{array}$ & & & & \\
\hline CRED_COND & & $\begin{array}{c}-0.106^{* * *} \\
(0.023)\end{array}$ & & & & & $\begin{array}{c}-0.079^{\star *} \\
(0.033)\end{array}$ & & & & & $\begin{array}{c}-0.167^{* * *} \\
(0.043)\end{array}$ & & & \\
\hline CRED_LINE & & & $\begin{array}{c}-0.115^{\star \star \star} \\
(0.023)\end{array}$ & & & & & $\begin{array}{c}-0.092^{\star * *} \\
(0.035)\end{array}$ & & & & & $\begin{array}{c}-0.158^{\star * *} \\
(0.045)\end{array}$ & & \\
\hline DEBT_INFO & & & & $\begin{array}{c}-0.100^{\star \star \star} \\
(0.027)\end{array}$ & & & & & $\begin{array}{c}-0.112^{\star \star \star} \\
(0.041)\end{array}$ & & & & & $\begin{array}{c}-0.193^{\star \star \star} \\
(0.059)\end{array}$ & \\
\hline VC_CONST & & & & & $\begin{array}{c}-0.110^{\star * *} \\
(0.029) \\
\end{array}$ & & & & & $\begin{array}{c}-0.099^{* *} \\
(0.041) \\
\end{array}$ & & & & & $\begin{array}{l}-0.107^{*} \\
(0.061) \\
\end{array}$ \\
\hline$N$ & 1589 & 1589 & 1589 & 1589 & 1589 & 911 & 911 & 911 & 911 & 911 & 615 & 615 & 615 & 615 & 615 \\
\hline Pseudo $\mathrm{R}^{2}$ & 0.075 & 0.072 & 0.074 & 0.068 & 0.068 & 0.050 & 0.046 & 0.048 & 0.049 & 0.046 & 0.083 & 0.081 & 0.077 & 0.074 & 0.061 \\
\hline Wald $\mathrm{chi}^{2}$ & $131.44^{* *}$ & $126.35^{\star * *}$ & $129.65^{\star * *}$ & $121.09^{\star * *}$ & $122.00^{* * *}$ & $49.55^{\star \star *}$ & $46.51^{\star \star *}$ & $47.54^{\star * *}$ & $47.54^{* * *}$ & $46.21^{* * *}$ & $44.96^{* \star *}$ & $44.12^{* * *}$ & $41.39^{* * *}$ & $40.86^{* * *}$ & $33.45^{\star *}$ \\
\hline
\end{tabular}

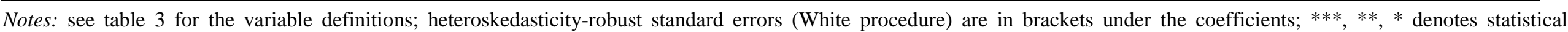
significance at the $1 \%, 5 \%$ and $10 \%$ test level, respectively. 
Table A.6: Growth of start-ups; OLS (unweighted)

\begin{tabular}{|c|c|c|c|c|c|c|c|c|c|c|c|c|c|c|c|}
\hline \multirow{2}{*}{$\begin{array}{l}\text { Period } \\
\text { Explanatory variables }\end{array}$} & \multicolumn{5}{|c|}{ GROWTH 1996/97-2000 } & \multicolumn{5}{|c|}{ GROWTH 2000-2003 } & \multicolumn{5}{|c|}{ GROWTH 2003-2006 } \\
\hline & $(1)$ & $(2)$ & (3) & (4) & $(5)$ & $(1)$ & $(2)$ & (3) & $(4)$ & $(5)$ & (1) & $(2)$ & (3) & (4) & (5) \\
\hline CONSTANT & $\begin{array}{c}0.798^{* * *} \\
(0.259)\end{array}$ & $\begin{array}{l}0.773^{* * *} \\
(0.264)\end{array}$ & $\begin{array}{l}0.771^{* * *} \\
(0.261)\end{array}$ & $\begin{array}{l}0.819^{* * *} \\
(0.260)\end{array}$ & $\begin{array}{l}0.831^{* \star *} \\
(0.259)\end{array}$ & $\begin{array}{l}0.982^{* \star *} \\
(0.316)\end{array}$ & $\begin{array}{c}0.995^{\star * *} \\
(0.316)\end{array}$ & $\begin{array}{l}1.002^{* \star *} \\
(0.316)\end{array}$ & $\begin{array}{l}1.031^{* * *} \\
(0.317)\end{array}$ & $\begin{array}{l}1.018^{\star * \star} \\
(0.316)\end{array}$ & $\begin{array}{l}0.836^{*} \\
(0.436)\end{array}$ & $\begin{array}{l}0.844^{*} \\
(0.437)\end{array}$ & $\begin{array}{l}0.854^{*} \\
(0.440)\end{array}$ & $\begin{array}{l}0.847^{*} \\
(0.448)\end{array}$ & $\begin{array}{l}0.812^{*} \\
(0.432)\end{array}$ \\
\hline MAIN & $\begin{array}{c}0.157^{\star \star *} \\
(0.048)\end{array}$ & $\begin{array}{l}0.157^{* * *} \\
(0.048)\end{array}$ & $\begin{array}{c}0.156^{\star * *} \\
(0.048)\end{array}$ & $\begin{array}{l}0.158^{* \star *} \\
(0.048)\end{array}$ & $\begin{array}{l}0.159^{* \star *} \\
(0.048)\end{array}$ & $\begin{array}{l}-0.008 \\
(0.061)\end{array}$ & $\begin{array}{l}-0.008 \\
(0.061)\end{array}$ & $\begin{array}{l}-0.008 \\
(0.061)\end{array}$ & $\begin{array}{l}-0.012 \\
(0.060)\end{array}$ & $\begin{array}{l}-0.010 \\
(0.060)\end{array}$ & $\begin{array}{l}-0.032 \\
(0.075)\end{array}$ & $\begin{array}{l}-0.031 \\
(0.076)\end{array}$ & $\begin{array}{l}-0.033 \\
(0.075)\end{array}$ & $\begin{array}{l}-0.034 \\
(0.075)\end{array}$ & $\begin{array}{l}-0.034 \\
(0.075)\end{array}$ \\
\hline UNEMPLOY & $\begin{array}{c}-0.100^{\star * *} \\
(0.035)\end{array}$ & $\begin{array}{l}-0.099^{* * *} \\
(0.035)\end{array}$ & $\begin{array}{l}-0.101^{* * *} \\
(0.035)\end{array}$ & $\begin{array}{l}-0.098^{* * *} \\
(0.035)\end{array}$ & $\begin{array}{l}-0.098^{* * *} \\
(0.035)\end{array}$ & $\begin{array}{l}-0.042 \\
(0.047)\end{array}$ & $\begin{array}{l}-0.045 \\
(0.047)\end{array}$ & $\begin{array}{l}-0.043 \\
(0.047)\end{array}$ & $\begin{array}{l}-0.041 \\
(0.047)\end{array}$ & $\begin{array}{l}-0.042 \\
(0.047)\end{array}$ & $\begin{array}{l}-0.044 \\
(0.050)\end{array}$ & $\begin{array}{l}-0.045 \\
(0.050)\end{array}$ & $\begin{array}{l}-0.045 \\
(0.050)\end{array}$ & $\begin{array}{l}-0.045 \\
(0.051)\end{array}$ & $\begin{array}{l}-0.049 \\
(0.050)\end{array}$ \\
\hline LAGE & $\begin{array}{c}-0.149^{\star \star} \\
(0.068)\end{array}$ & $\begin{array}{l}-0.149^{\star \star} \\
(0.068)\end{array}$ & $\begin{array}{c}-0.148^{\star \star} \\
(0.068)\end{array}$ & $\begin{array}{l}-0.158^{\star \star} \\
(0.067)\end{array}$ & $\begin{array}{l}-0.160^{\star \star} \\
(0.067)\end{array}$ & $\begin{array}{c}-0.232^{\star \star \star} \\
(0.081)\end{array}$ & $\begin{array}{c}-0.234^{\star * \star} \\
(0.081)\end{array}$ & $\begin{array}{c}-0.233^{\star \star \star} \\
(0.081)\end{array}$ & $\begin{array}{c}-0.228^{\star \star \star} \\
(0.081)\end{array}$ & $\begin{array}{c}-0.234^{\star \star *} \\
(0.081)\end{array}$ & $\begin{array}{l}-0.213^{\star} \\
(0.112)\end{array}$ & $\begin{array}{l}-0.210^{*} \\
(0.111)\end{array}$ & $\begin{array}{l}-0.212^{*} \\
(0.111)\end{array}$ & $\begin{array}{l}-0.211^{\star} \\
(0.112)\end{array}$ & $\begin{array}{l}-0.205^{\star} \\
(0.110)\end{array}$ \\
\hline GENDER & $\begin{array}{l}-0.029 \\
(0.034)\end{array}$ & $\begin{array}{l}-0.029 \\
(0.034)\end{array}$ & $\begin{array}{l}-0.030 \\
(0.034)\end{array}$ & $\begin{array}{l}-0.028 \\
(0.034)\end{array}$ & $\begin{array}{l}-0.027 \\
(0.034)\end{array}$ & $\begin{array}{c}0.031 \\
(0.043)\end{array}$ & $\begin{array}{c}0.030 \\
(0.043)\end{array}$ & $\begin{array}{c}0.030 \\
(0.043)\end{array}$ & $\begin{array}{c}0.034 \\
(0.043)\end{array}$ & $\begin{array}{c}0.033 \\
(0.043)\end{array}$ & $\begin{array}{c}0.022 \\
(0.047)\end{array}$ & $\begin{array}{c}0.021 \\
(0.047)\end{array}$ & $\begin{array}{c}0.022 \\
(0.047)\end{array}$ & $\begin{array}{c}0.022 \\
(0.047)\end{array}$ & $\begin{array}{c}0.021 \\
(0.047)\end{array}$ \\
\hline QUAL & $\begin{array}{l}0.078^{\star \star} \\
(0.031)\end{array}$ & $\begin{array}{l}0.077^{\text {** }} \\
(0.031)\end{array}$ & $\begin{array}{l}0.078^{* *} \\
(0.031)\end{array}$ & $\begin{array}{l}0.076^{* *} \\
(0.031)\end{array}$ & $\begin{array}{l}0.075^{\star *} \\
(0.031)\end{array}$ & $\begin{array}{l}0.091^{* *} \\
(0.038)\end{array}$ & $\begin{array}{l}0.094^{* *} \\
(0.038)\end{array}$ & $\begin{array}{l}0.092^{* *} \\
(0.038)\end{array}$ & $\begin{array}{l}0.090^{* *} \\
(0.038)\end{array}$ & $\begin{array}{l}0.095^{\star *} \\
(0.038)\end{array}$ & $\begin{array}{l}0.083^{*} \\
(0.043)\end{array}$ & $\begin{array}{c}0.082^{*} \\
(0.044)\end{array}$ & $\begin{array}{l}0.082^{*} \\
(0.043)\end{array}$ & $\begin{array}{l}0.085^{\star *} \\
(0.043)\end{array}$ & $\begin{array}{l}0.085^{*} \\
(0.043)\end{array}$ \\
\hline$R \& D$ & $\begin{array}{c}0.032 \\
(0.040)\end{array}$ & $\begin{array}{c}0.033 \\
(0.040)\end{array}$ & $\begin{array}{c}0.031 \\
(0.040)\end{array}$ & $\begin{array}{c}0.034 \\
(0.040)\end{array}$ & $\begin{array}{c}0.034 \\
(0.041)\end{array}$ & $\begin{array}{l}-0.008 \\
(0.044)\end{array}$ & $\begin{array}{l}-0.010 \\
(0.044)\end{array}$ & $\begin{array}{l}-0.010 \\
(0.044)\end{array}$ & $\begin{array}{l}-0.001 \\
(0.043)\end{array}$ & $\begin{array}{l}-0.008 \\
(0.044)\end{array}$ & $\begin{array}{l}-0.038 \\
(0.062)\end{array}$ & $\begin{array}{l}-0.039 \\
(0.062)\end{array}$ & $\begin{array}{l}-0.038 \\
(0.062)\end{array}$ & $\begin{array}{l}-0.039 \\
(0.062)\end{array}$ & $\begin{array}{l}-0.040 \\
(0.062)\end{array}$ \\
\hline NP & $\begin{array}{l}0.091^{* *} \\
(0.043)\end{array}$ & $\begin{array}{l}0.091^{* *} \\
(0.044)\end{array}$ & $\begin{array}{l}0.091^{* *} \\
(0.043)\end{array}$ & $\begin{array}{l}0.094^{* *} \\
(0.044)\end{array}$ & $\begin{array}{l}0.094^{* *} \\
(0.044)\end{array}$ & $\begin{array}{l}0.140^{\star *} \\
(0.055)\end{array}$ & $\begin{array}{l}0.140^{* *} \\
(0.055)\end{array}$ & $\begin{array}{l}0.140^{* *} \\
(0.055)\end{array}$ & $\begin{array}{l}0.139^{* *} \\
(0.055)\end{array}$ & $\begin{array}{l}0.141^{\star *} \\
(0.055)\end{array}$ & $\begin{array}{l}0.146^{* *} \\
(0.067)\end{array}$ & $\begin{array}{l}0.144^{\star *} \\
(0.067)\end{array}$ & $\begin{array}{l}0.145^{\star *} \\
(0.067)\end{array}$ & $\begin{array}{l}0.145^{\star *} \\
(0.068)\end{array}$ & $\begin{array}{l}0.143^{\star *} \\
(0.068)\end{array}$ \\
\hline MP & $\begin{array}{c}0.093^{* * *} \\
(0.031)\end{array}$ & $\begin{array}{c}0.093^{* \star *} \\
(0.031)\end{array}$ & $\begin{array}{c}0.093^{\star * *} \\
(0.031)\end{array}$ & $\begin{array}{c}0.094^{* \star *} \\
(0.031)\end{array}$ & $\begin{array}{c}0.095^{\star \star *} \\
(0.031)\end{array}$ & $\begin{array}{c}0.017 \\
(0.035)\end{array}$ & $\begin{array}{c}0.014 \\
(0.035)\end{array}$ & $\begin{array}{c}0.016 \\
(0.035)\end{array}$ & $\begin{array}{c}0.019 \\
(0.035)\end{array}$ & $\begin{array}{c}0.017 \\
(0.035)\end{array}$ & $\begin{array}{c}0.131^{* * *} \\
(0.045)\end{array}$ & $\begin{array}{c}0.131^{* * *} \\
(0.045)\end{array}$ & $\begin{array}{c}0.130^{\star * *} \\
(0.044)\end{array}$ & $\begin{array}{c}0.130^{* \star *} \\
(0.044)\end{array}$ & $\begin{array}{c}0.130^{\star * *} \\
(0.044)\end{array}$ \\
\hline PCOMP & $\begin{array}{l}-0.012 \\
(0.028)\end{array}$ & $\begin{array}{l}-0.012 \\
(0.028)\end{array}$ & $\begin{array}{l}-0.013 \\
(0.028)\end{array}$ & $\begin{array}{l}-0.010 \\
(0.029)\end{array}$ & $\begin{array}{l}-0.010 \\
(0.029)\end{array}$ & $\begin{array}{c}0.051 \\
(0.034)\end{array}$ & $\begin{array}{c}0.047 \\
(0.035)\end{array}$ & $\begin{array}{c}0.049 \\
(0.035)\end{array}$ & $\begin{array}{c}0.053 \\
(0.034)\end{array}$ & $\begin{array}{c}0.049 \\
(0.035)\end{array}$ & $\begin{array}{c}0.013 \\
(0.040)\end{array}$ & $\begin{array}{c}0.015 \\
(0.040)\end{array}$ & $\begin{array}{c}0.013 \\
(0.040)\end{array}$ & $\begin{array}{c}0.012 \\
(0.040)\end{array}$ & $\begin{array}{c}0.014 \\
(0.040)\end{array}$ \\
\hline NPCOMP & $\begin{array}{l}-0.006 \\
(0.029)\end{array}$ & $\begin{array}{l}-0.006 \\
(0.029)\end{array}$ & $\begin{array}{l}-0.005 \\
(0.029)\end{array}$ & $\begin{array}{l}-0.006 \\
(0.029)\end{array}$ & $\begin{array}{l}-0.006 \\
(0.029)\end{array}$ & $\begin{array}{c}0.094^{* * *} \\
(0.035)\end{array}$ & $\begin{array}{c}0.093^{* * *} \\
(0.035)\end{array}$ & $\begin{array}{c}0.093^{* * *} \\
(0.035)\end{array}$ & $\begin{array}{c}0.094^{* * *} \\
(0.035)\end{array}$ & $\begin{array}{c}0.094^{* * *} \\
(0.035)\end{array}$ & $\begin{array}{l}-0.018 \\
(0.040)\end{array}$ & $\begin{array}{l}-0.019 \\
(0.040)\end{array}$ & $\begin{array}{l}-0.017 \\
(0.040)\end{array}$ & $\begin{array}{l}-0.019 \\
(0.040)\end{array}$ & $\begin{array}{l}-0.019 \\
(0.040)\end{array}$ \\
\hline LCAP & $\begin{array}{l}0.015^{*} \\
(0.008)\end{array}$ & $\begin{array}{l}0.015^{*} \\
(0.008)\end{array}$ & $\begin{array}{l}0.015^{*} \\
(0.008)\end{array}$ & $\begin{array}{l}0.015^{*} \\
(0.008)\end{array}$ & $\begin{array}{l}0.015^{\star} \\
(0.008)\end{array}$ & $\begin{array}{c}0.006 \\
(0.008)\end{array}$ & $\begin{array}{c}0.005 \\
(0.008)\end{array}$ & $\begin{array}{c}0.006 \\
(0.008)\end{array}$ & $\begin{array}{c}0.005 \\
(0.008)\end{array}$ & $\begin{array}{c}0.006 \\
(0.008)\end{array}$ & $\begin{array}{c}0.004 \\
(0.010)\end{array}$ & $\begin{array}{c}0.004 \\
(0.010)\end{array}$ & $\begin{array}{c}0.004 \\
(0.010)\end{array}$ & $\begin{array}{c}0.004 \\
(0.010)\end{array}$ & $\begin{array}{c}0.005 \\
(0.010)\end{array}$ \\
\hline$A G$ & $\begin{array}{c}0.536^{\star * *} \\
(0.060)\end{array}$ & $\begin{array}{c}0.535^{\star \star *} \\
(0.060)\end{array}$ & $\begin{array}{c}0.534^{\star * *} \\
(0.060)\end{array}$ & $\begin{array}{c}0.539^{* \star *} \\
(0.060)\end{array}$ & $\begin{array}{c}0.539^{\star * \star} \\
(0.060)\end{array}$ & $\begin{array}{c}0.319^{\star \star \star} \\
(0.060)\end{array}$ & $\begin{array}{c}0.320^{\star \star \star} \\
(0.060)\end{array}$ & $\begin{array}{c}0.320^{\star \star *} \\
(0.060)\end{array}$ & $\begin{array}{c}0.317^{\star \star *} \\
(0.060)\end{array}$ & $\begin{array}{c}0.322^{* \star *} \\
(0.060)\end{array}$ & $\begin{array}{l}0.173^{\star *} \\
(0.076)\end{array}$ & $\begin{array}{l}0.174^{\star *} \\
(0.076)\end{array}$ & $\begin{array}{l}0.172^{* *} \\
(0.076)\end{array}$ & $\begin{array}{l}0.174^{\star \star} \\
(0.076)\end{array}$ & $\begin{array}{l}0.174^{\star *} \\
(0.076)\end{array}$ \\
\hline GMBH & $\begin{array}{c}0.120^{* * *} \\
(0.034)\end{array}$ & $\begin{array}{c}0.119^{* * *} \\
(0.034)\end{array}$ & $\begin{array}{c}0.119^{* * *} \\
(0.034)\end{array}$ & $\begin{array}{c}0.122^{* * *} \\
(0.034)\end{array}$ & $\begin{array}{c}0.122^{* * *} \\
(0.034)\end{array}$ & $\begin{array}{c}0.127^{\star * *} \\
(0.041)\end{array}$ & $\begin{array}{c}0.125^{\star * \star} \\
(0.041)\end{array}$ & $\begin{array}{c}0.126^{* \star *} \\
(0.040)\end{array}$ & $\begin{array}{c}0.132^{* * *} \\
(0.041)\end{array}$ & $\begin{array}{c}0.128^{* * *} \\
(0.040)\end{array}$ & $\begin{array}{c}0.056 \\
(0.048)\end{array}$ & $\begin{array}{c}0.055 \\
(0.048)\end{array}$ & $\begin{array}{c}0.055 \\
(0.048)\end{array}$ & $\begin{array}{c}0.056 \\
(0.048)\end{array}$ & $\begin{array}{c}0.053 \\
(0.048)\end{array}$ \\
\hline OTHER & $\begin{array}{c}0.001 \\
(0.044)\end{array}$ & $\begin{array}{c}0.002 \\
(0.044)\end{array}$ & $\begin{array}{c}0.001 \\
(0.044)\end{array}$ & $\begin{array}{c}0.002 \\
(0.044)\end{array}$ & $\begin{array}{c}0.002 \\
(0.044)\end{array}$ & $\begin{array}{c}0.058 \\
(0.098)\end{array}$ & $\begin{array}{c}0.061 \\
(0.097)\end{array}$ & $\begin{array}{c}0.059 \\
(0.098)\end{array}$ & $\begin{array}{c}0.058 \\
(0.098)\end{array}$ & $\begin{array}{c}0.062 \\
(0.098)\end{array}$ & $\begin{array}{c}0.152 \\
(0.113)\end{array}$ & $\begin{array}{c}0.151 \\
(0.113)\end{array}$ & $\begin{array}{c}0.150 \\
(0.113)\end{array}$ & $\begin{array}{c}0.153 \\
(0.112)\end{array}$ & $\begin{array}{c}0.151 \\
(0.113)\end{array}$ \\
\hline LSIZE & $\begin{array}{c}-0.357^{* * *} \\
(0.046)\end{array}$ & $\begin{array}{c}-0.356^{\star * *} \\
(0.046)\end{array}$ & $\begin{array}{c}-0.358^{\star * *} \\
(0.046)\end{array}$ & $\begin{array}{c}-0.356^{* * *} \\
(0.046)\end{array}$ & $\begin{array}{c}-0.356^{* * *} \\
(0.046)\end{array}$ & $\begin{array}{c}-0.223^{* * *} \\
(0.049)\end{array}$ & $\begin{array}{c}-0.225^{\star * *} \\
(0.049)\end{array}$ & $\begin{array}{c}-0.224^{* * *} \\
(0.049)\end{array}$ & $\begin{array}{c}-0.222^{\star * \star} \\
(0.049)\end{array}$ & $\begin{array}{c}-0.223^{* * *} \\
(0.049)\end{array}$ & $\begin{array}{l}-0.106^{\star} \\
(0.063)\end{array}$ & $\begin{array}{l}-0.106^{*} \\
(0.063)\end{array}$ & $\begin{array}{l}-0.105^{*} \\
(0.063)\end{array}$ & $\begin{array}{l}-0.107^{\star} \\
(0.064)\end{array}$ & $\begin{array}{l}-0.107^{*} \\
(0.064)\end{array}$ \\
\hline IND_1 & $\begin{array}{c}-0.201^{* * *} \\
(0.067)\end{array}$ & $\begin{array}{c}-0.200^{* * *} \\
(0.067)\end{array}$ & $\begin{array}{c}-0.202^{* * *} \\
(0.067)\end{array}$ & $\begin{array}{c}-0.199^{\star * *} \\
(0.067)\end{array}$ & $\begin{array}{c}-0.199^{* * *} \\
(0.067)\end{array}$ & $\begin{array}{l}-0.088 \\
(0.083)\end{array}$ & $\begin{array}{l}-0.092 \\
(0.083)\end{array}$ & $\begin{array}{l}-0.088 \\
(0.083)\end{array}$ & $\begin{array}{l}-0.101 \\
(0.082)\end{array}$ & $\begin{array}{l}-0.086 \\
(0.084)\end{array}$ & $\begin{array}{l}-0.050 \\
(0.084)\end{array}$ & $\begin{array}{l}-0.049 \\
(0.084)\end{array}$ & $\begin{array}{l}-0.047 \\
(0.085)\end{array}$ & $\begin{array}{l}-0.053 \\
(0.083)\end{array}$ & $\begin{array}{l}-0.050 \\
(0.085)\end{array}$ \\
\hline IND_2 & $\begin{array}{c}-0.243^{* \star *} \\
(0.052)\end{array}$ & $\begin{array}{c}-0.242^{* \star *} \\
(0.052)\end{array}$ & $\begin{array}{c}-0.242^{\star * *} \\
(0.052)\end{array}$ & $\begin{array}{c}-0.246^{\star * *} \\
(0.052)\end{array}$ & $\begin{array}{c}-0.246^{* \star *} \\
(0.052)\end{array}$ & $\begin{array}{c}-0.143^{* *} \\
(0.060)\end{array}$ & $\begin{array}{c}-0.142^{\star *} \\
(0.060)\end{array}$ & $\begin{array}{c}-0.142^{* *} \\
(0.060)\end{array}$ & $\begin{array}{c}-0.155^{\star *} \\
(0.060)\end{array}$ & $\begin{array}{c}-0.143^{\star *} \\
(0.060)\end{array}$ & $\begin{array}{l}-0.141^{*} \\
(0.077)\end{array}$ & $\begin{array}{l}-0.141^{*} \\
(0.077)\end{array}$ & $\begin{array}{l}-0.138^{*} \\
(0.078)\end{array}$ & $\begin{array}{l}-0.140^{*} \\
(0.078)\end{array}$ & $\begin{array}{l}-0.136^{*} \\
(0.079)\end{array}$ \\
\hline
\end{tabular}




\begin{tabular}{|c|c|c|c|c|c|c|c|c|c|c|c|c|c|c|c|}
\hline IND_3 & $\begin{array}{c}-0.162^{\star * \star} \\
(0.051)\end{array}$ & $\begin{array}{c}-0.160^{\star \star \star} \\
(0.051)\end{array}$ & $\begin{array}{c}-0.161^{\star \star *} \\
(0.051)\end{array}$ & $\begin{array}{c}-0.160^{\star \star *} \\
(0.051)\end{array}$ & $\begin{array}{c}-0.159^{\star * *} \\
(0.051)\end{array}$ & $\begin{array}{l}-0.056 \\
(0.060)\end{array}$ & $\begin{array}{l}-0.062 \\
(0.061)\end{array}$ & $\begin{array}{l}-0.058 \\
(0.061)\end{array}$ & $\begin{array}{l}-0.063 \\
(0.060)\end{array}$ & $\begin{array}{l}-0.057 \\
(0.060)\end{array}$ & $\begin{array}{l}-0.104 \\
(0.075)\end{array}$ & $\begin{array}{l}-0.103 \\
(0.075)\end{array}$ & $\begin{array}{l}-0.102 \\
(0.075)\end{array}$ & $\begin{array}{l}-0.105 \\
(0.075)\end{array}$ & $\begin{array}{l}-0.103 \\
(0.075)\end{array}$ \\
\hline DEBT_CONST & $\begin{array}{c}0.007 \\
(0.005)\end{array}$ & & & & & $\begin{array}{l}-0.006 \\
(0.007)\end{array}$ & & & & & $\begin{array}{l}-0.006 \\
(0.009)\end{array}$ & & & & \\
\hline CRED_COND & & $\begin{array}{c}0.012 \\
(0.010)\end{array}$ & & & & & $\begin{array}{c}0.002 \\
(0.013)\end{array}$ & & & & & $\begin{array}{l}-0.011 \\
(0.016)\end{array}$ & & & \\
\hline CRED_LINE & & & $\begin{array}{c}0.015 \\
(0.010)\end{array}$ & & & & & $\begin{array}{l}-0.005 \\
(0.013)\end{array}$ & & & & & $\begin{array}{l}-0.013 \\
(0.017)\end{array}$ & & \\
\hline DEBT_INFO & & & & $\begin{array}{c}0.004 \\
(0.010)\end{array}$ & & & & & $\begin{array}{l}-0.032^{*} \\
(0.017)\end{array}$ & & & & & $\begin{array}{l}-0.012 \\
(0.022)\end{array}$ & \\
\hline VC_CONST & & & & & $\begin{array}{c}0.002 \\
(0.012) \\
\end{array}$ & & & & & $\begin{array}{l}-0.020 \\
(0.018) \\
\end{array}$ & & & & & $\begin{array}{l}-0.006 \\
(0.022) \\
\end{array}$ \\
\hline $\mathrm{N}$ & 1589 & 1589 & 1589 & 1589 & 1589 & 911 & 911 & 911 & 911 & 911 & 615 & 615 & 615 & 615 & 615 \\
\hline$R^{2}$ & 0.144 & 0.144 & 0.145 & 0.143 & 0.143 & 0.090 & 0.089 & 0.090 & 0.094 & 0.091 & 0.058 & 0.058 & 0.058 & 0.057 & 0.057 \\
\hline $\mathrm{F}$ & $8.71^{\star \star \star}$ & $8.69^{\star \star \star}$ & $8.78^{\star \star \star}$ & $8.62^{\star \star \star}$ & $8.67^{\star * \star}$ & $4.27^{\star \star \star}$ & $4.28^{* * *}$ & $4.27^{\star \star \star}$ & $4.44^{* * *}$ & $4.39^{\star \star \star}$ & $1.72^{\star *}$ & $1.73^{* *}$ & $1.72^{* *}$ & $1.70^{\star *}$ & $1.70^{* *}$ \\
\hline
\end{tabular}

Notes: see table 3 for the variable definitions; heteroskedasticity-robust standard errors (White procedure) are in brackets under the coefficients; ***, **, * denotes statistical significance at the $1 \%, 5 \%$ and $10 \%$ test level, respectively. 
Table A.7: Employment growth of start-ups

\begin{tabular}{|c|c|c|c|c|c|c|}
\hline Period & \multicolumn{2}{|c|}{$1996 / 97-2000$} & \multicolumn{2}{|c|}{$2000-2003$} & \multicolumn{2}{|c|}{$2003-2006$} \\
\hline Employment growth & $\mathrm{N}$ & $\begin{array}{l}\text { Percentage } \\
\text { of firms }\end{array}$ & $\mathrm{N}$ & $\begin{array}{l}\text { Percentage } \\
\text { of firms }\end{array}$ & $\mathrm{N}$ & $\begin{array}{c}\text { Percentage } \\
\text { of firms }\end{array}$ \\
\hline Decrease of more than 2 employees & 16 & 1.0 & 25 & 2.7 & 22 & 3.6 \\
\hline Decrease of $0-2$ employees & 275 & 17.3 & 158 & 17.3 & 159 & 25.9 \\
\hline No change & 575 & 36.2 & 353 & 38.7 & 212 & 34.5 \\
\hline Increase of $0-2$ employees & 507 & 31.9 & 268 & 29.4 & 167 & 27.2 \\
\hline Increase of 2 - 4 employees & 127 & 8.0 & 62 & 6.8 & 24 & 3.9 \\
\hline Increase of more than 4 employees & 89 & 5.6 & 45 & 4.9 & 31 & 5.0 \\
\hline $\mathrm{N}$ & 1589 & 100 & 911 & 100 & 615 & 100 \\
\hline average increase & & 0.88 & & 0.78 & & 1.46 \\
\hline
\end{tabular}

Table A.8: Descriptive statistics

\begin{tabular}{|c|c|c|c|c|c|c|}
\hline \multirow[t]{2}{*}{ Period } & \multicolumn{2}{|c|}{$2000(\mathrm{~N}=1589)$} & \multicolumn{2}{|c|}{$2003(\mathrm{~N}=911)$} & \multicolumn{2}{|c|}{$2006(\mathrm{~N}=615)$} \\
\hline & Mean & $\begin{array}{l}\text { Standard } \\
\text { deviation }\end{array}$ & Mean & $\begin{array}{l}\text { Standard } \\
\text { deviation }\end{array}$ & Mean & $\begin{array}{l}\text { Standard } \\
\text { deviation }\end{array}$ \\
\hline SURVIVING & 0.824 & 0.381 & 0.907 & 0.291 & & \\
\hline BREAK & 0.722 & 0.448 & 0.782 & 0.413 & 0.833 & 0.374 \\
\hline GROWTH & 0.217 & 0.605 & 0.128 & 0.534 & 0.023 & 0.508 \\
\hline MAIN & 0.831 & 0.375 & 0.849 & 0.359 & 0.852 & 0.355 \\
\hline UNEMPLOY & 0.130 & 0.336 & 0.134 & 0.341 & 0.140 & 0.347 \\
\hline LAGE & 3.652 & 0.217 & 3.656 & 0.210 & 3.650 & 0.212 \\
\hline GENDER & 0.767 & 0.423 & 0.751 & 0.433 & 0.750 & 0.434 \\
\hline QUAL & 0.659 & 0.474 & 0.697 & 0.460 & 0.691 & 0.462 \\
\hline$R \& D$ & 0.234 & 0.424 & 0.189 & 0.392 & 0.154 & 0.362 \\
\hline NP & 0.149 & 0.356 & 0.112 & 0.315 & 0.124 & 0.329 \\
\hline MP & 0.403 & 0.491 & 0.387 & 0.487 & 0.372 & 0.484 \\
\hline PCOMP & 0.422 & 0.494 & 0.483 & 0.500 & 0.486 & 0.500 \\
\hline NPCOMP & 0.536 & 0.499 & 0.526 & 0.500 & 0.515 & 0.500 \\
\hline LCAP & 10.553 & 1.959 & 10.559 & 1.832 & 10.537 & 1.788 \\
\hline$A G$ & 0.163 & 0.369 & 0.181 & 0.385 & 0.151 & 0.359 \\
\hline GMBH & 0.254 & 0.436 & 0.262 & 0.440 & 0.306 & 0.461 \\
\hline OTHER & 0.097 & 0.296 & 0.041 & 0.198 & 0.041 & 0.198 \\
\hline LSIZE & 1.069 & 0.555 & 1.150 & 0.632 & 1.186 & 0.716 \\
\hline IND_1 & 0.084 & 0.278 & 0.080 & 0.272 & 0.081 & 0.274 \\
\hline IND_2 & 0.444 & 0.497 & 0.462 & 0.499 & 0.506 & 0.500 \\
\hline IND_3 & 0.379 & 0.485 & 0.368 & 0.482 & 0.320 & 0.467 \\
\hline DEBT_CONST & 0.002 & 2.621 & 0.011 & 2.626 & -0.024 & 2.671 \\
\hline CRED_COND & 2.047 & 1.514 & 2.113 & 1.419 & 1.896 & 1.406 \\
\hline CRED_LINE & 2.014 & 1.502 & 2.019 & 1.354 & 1.789 & 1.341 \\
\hline DEBT_INFO & 1.711 & 1.282 & 1.699 & 1.138 & 1.511 & 1.027 \\
\hline VC_CONST & 1.566 & 1.169 & 1.529 & 1.098 & 1.395 & 0.971 \\
\hline
\end{tabular}


Table A.9a: Correlation matrix for cross-section 2000 (N=1589)

\begin{tabular}{|c|c|c|c|c|c|c|c|c|c|c|c|c|c|c|c|c|c|c|c|c|c|c|c|c|c|}
\hline & SURVIVING & BREAK & GROWTH & MAIN & UNEMPLOY & LAGE & GENDER & QUAL & $R \& D$ & $\mathrm{NP}$ & MP & PCOMP & NPCOMP & LCAP & $A G$ & GMBH & OTHER & LSIZE & IND_1 & IND_2 & IND_3 & $\begin{array}{l}\text { DEBT } \\
\text { CONST }\end{array}$ & $\begin{array}{l}\text { CRED } \\
\text { COND }\end{array}$ & $\begin{array}{l}\text { CRED } \\
\text { LINE }^{-}\end{array}$ & $\begin{array}{l}\text { DEBT } \\
\text { NFO }\end{array}$ \\
\hline BREAK & 0.101 & & & & & & & & & & & & & & & & & & & & & & & & \\
\hline GROWTH & 0.038 & 0.035 & & & & & & & & & & & & & & & & & & & & & & & \\
\hline MAIN & 0.070 & 0.114 & 0.080 & & & & & & & & & & & & & & & & & & & & & & \\
\hline UNEMPLOY & 0.026 & -0.041 & -0.085 & 0.044 & & & & & & & & & & & & & & & & & & & & & \\
\hline LAGE & 0.035 & 0.029 & -0.036 & 0.046 & 0.066 & & & & & & & & & & & & & & & & & & & & \\
\hline GENDER & -0.036 & 0.062 & 0.008 & 0.057 & 0.054 & 0.017 & & & & & & & & & & & & & & & & & & & \\
\hline QUAL & -0.011 & 0.090 & 0.072 & -0.019 & -0.078 & 0.098 & 0.052 & & & & & & & & & & & & & & & & & & \\
\hline$R \& D$ & -0.011 & -0.008 & 0.065 & -0.041 & 0.017 & 0.037 & 0.063 & 0.188 & & & & & & & & & & & & & & & & & \\
\hline NPCOMP & -0.025 & -0.052 & 0.061 & -0.066 & -0.025 & -0.012 & 0.018 & 0.063 & 0.232 & & & & & & & & & & & & & & & & \\
\hline MP & 0.046 & 0.038 & 0.113 & 0.004 & -0.008 & 0.000 & 0.005 & 0.132 & 0.327 & 0.023 & & & & & & & & & & & & & & & \\
\hline PCOMP & -0.024 & -0.044 & -0.002 & -0.016 & 0.004 & -0.048 & -0.025 & -0.027 & -0.021 & 0.003 & -0.017 & & & & & & & & & & & & & & \\
\hline NPCOMP & -0.015 & 0.028 & 0.020 & 0.013 & 0.006 & -0.028 & 0.042 & 0.079 & 0.127 & 0.071 & 0.189 & 0.100 & & & & & & & & & & & & & \\
\hline LCAP & 0.072 & -0.009 & 0.082 & 0.071 & -0.057 & 0.115 & 0.017 & 0.030 & 0.009 & -0.002 & 0.028 & 0.054 & 0.033 & & & & & & & & & & & & \\
\hline$A G$ & 0.029 & 0.072 & 0.255 & 0.003 & -0.109 & 0.065 & 0.107 & 0.123 & 0.062 & 0.031 & 0.137 & -0.001 & 0.052 & 0.206 & & & & & & & & & & & \\
\hline GMBH & -0.008 & -0.073 & -0.008 & -0.034 & -0.053 & -0.052 & -0.207 & -0.016 & 0.029 & 0.011 & 0.009 & 0.083 & 0.016 & -0.046 & -0.258 & & & & & & & & & & \\
\hline OTHER & 0.006 & 0.009 & -0.057 & -0.017 & 0.007 & -0.002 & -0.020 & 0.038 & 0.005 & -0.030 & -0.014 & -0.039 & -0.045 & -0.036 & -0.145 & -0.191 & & & & & & & & & \\
\hline LSIZE & 0.044 & 0.054 & 0.660 & 0.080 & -0.121 & -0.035 & 0.012 & 0.104 & 0.050 & 0.066 & 0.134 & 0.014 & 0.029 & 0.184 & 0.441 & 0.033 & -0.069 & & & & & & & & \\
\hline IND_1 & 0.021 & -0.085 & -0.014 & 0.022 & 0.072 & 0.020 & 0.028 & -0.111 & 0.084 & 0.013 & 0.004 & 0.025 & 0.005 & -0.006 & -0.017 & 0.036 & -0.008 & -0.014 & & & & & & & \\
\hline IND_2 & -0.044 & 0.195 & -0.009 & 0.044 & -0.051 & 0.065 & 0.104 & 0.285 & 0.149 & 0.003 & 0.095 & -0.030 & 0.135 & -0.050 & 0.117 & -0.015 & 0.011 & -0.050 & -0.271 & & & & & & \\
\hline IND_3 & 0.037 & -0.172 & -0.018 & -0.109 & 0.000 & -0.034 & -0.188 & -0.155 & -0.119 & 0.030 & -0.058 & 0.002 & -0.075 & 0.071 & -0.095 & 0.012 & -0.019 & 0.000 & -0.237 & -0.697 & & & & & \\
\hline $\begin{array}{l}\text { DEBT } \\
\text { CONST }\end{array}$ & -0.045 & -0.163 & 0.050 & 0.010 & 0.053 & -0.148 & 0.018 & -0.091 & 0.071 & 0.081 & 0.056 & 0.082 & 0.012 & -0.002 & 0.034 & 0.046 & -0.024 & 0.071 & 0.071 & -0.147 & 0.104 & & & & \\
\hline $\begin{array}{l}\text { CRED } \\
\text { COND } \\
\text { CRED }\end{array}$ & -0.048 & -0.152 & 0.058 & 0.005 & 0.023 & -0.141 & 0.007 & -0.079 & 0.038 & 0.077 & 0.042 & 0.088 & 0.007 & 0.012 & 0.032 & 0.061 & -0.038 & 0.070 & 0.059 & -0.156 & 0.108 & 0.893 & & & \\
\hline $\begin{array}{l}\text { LINE } \\
\text { DEBT }\end{array}$ & -0.032 & -0.153 & 0.061 & 0.026 & 0.054 & -0.114 & 0.037 & -0.084 & 0.065 & 0.073 & 0.053 & 0.088 & -0.005 & 0.034 & 0.056 & 0.034 & -0.023 & 0.095 & 0.080 & -0.136 & 0.077 & 0.902 & 0.769 & & \\
\hline INFO' & -0.038 & -0.123 & 0.012 & -0.005 & 0.062 & -0.133 & 0.003 & -0.076 & 0.083 & 0.063 & 0.052 & 0.039 & 0.029 & -0.051 & 0.001 & 0.026 & -0.002 & 0.020 & 0.046 & -0.094 & 0.086 & 0.825 & 0.569 & 0.592 & \\
\hline CONSTT & -0.019 & -0.123 & 0.016 & -0.047 & 0.060 & -0.065 & -0.013 & 0.046 & 0.162 & 0.080 & 0.079 & 0.077 & 0.030 & -0.011 & 0.030 & 0.038 & -0.024 & 0.032 & 0.051 & -0.047 & 0.068 & 0.490 & 0.428 & 0.432 & 0.423 \\
\hline
\end{tabular}


Table A.9b: Correlation matrix for cross-section 2003 (N=911)

\begin{tabular}{|c|c|c|c|c|c|c|c|c|c|c|c|c|c|c|c|c|c|c|c|c|c|c|c|c|c|}
\hline & SURVIVING & BREAK & GROWTH & MAIN & UNEMPLOY & LAGE & GENDER & QUAL & $R \& D$ & $\mathrm{NP}$ & MP & PCOMP & NPCOMP & LCAP & $A G$ & GMBH & OTHER & LSIZE & IND_1 & IND_2 & IND_3 & $\begin{array}{l}\text { DEBT } \\
\text { CONST }\end{array}$ & $\begin{array}{l}\text { CRED } \\
\text { COND }\end{array}$ & $\begin{array}{l}\text { CRED } \\
\text { LINE }^{-}\end{array}$ & $\begin{array}{l}\text { DEBT } \\
\text { INFO }\end{array}$ \\
\hline BREAK & 0.050 & & & & & & & & & & & & & & & & & & & & & & & & \\
\hline GROWTH & 0.078 & 0.117 & & & & & & & & & & & & & & & & & & & & & & & \\
\hline MAIN & 0.012 & 0.073 & -0.041 & & & & & & & & & & & & & & & & & & & & & & \\
\hline UNEMPLOY & -0.029 & -0.026 & -0.044 & 0.067 & & & & & & & & & & & & & & & & & & & & & \\
\hline LAGE & -0.089 & 0.018 & -0.085 & 0.051 & 0.070 & & & & & & & & & & & & & & & & & & & & \\
\hline GENDER & -0.010 & 0.039 & 0.016 & 0.061 & 0.048 & 0.012 & & & & & & & & & & & & & & & & & & & \\
\hline QUAL & 0.043 & 0.045 & 0.066 & -0.039 & -0.091 & 0.076 & 0.062 & & & & & & & & & & & & & & & & & & \\
\hline$R \& D$ & 0.010 & -0.064 & 0.029 & -0.062 & 0.000 & -0.044 & 0.064 & 0.098 & & & & & & & & & & & & & & & & & \\
\hline NPCOMP & 0.006 & 0.070 & 0.101 & -0.044 & -0.027 & -0.034 & 0.028 & 0.037 & 0.211 & & & & & & & & & & & & & & & & \\
\hline MP & 0.023 & 0.017 & 0.048 & -0.003 & -0.002 & -0.039 & -0.016 & 0.088 & 0.267 & 0.082 & & & & & & & & & & & & & & & \\
\hline PCOMP & -0.007 & -0.021 & 0.069 & 0.010 & 0.007 & -0.062 & -0.027 & 0.040 & 0.016 & 0.040 & 0.025 & & & & & & & & & & & & & & \\
\hline NPCOMP & -0.010 & 0.051 & 0.099 & -0.015 & 0.031 & -0.014 & -0.029 & 0.034 & 0.076 & 0.044 & 0.106 & 0.029 & & & & & & & & & & & & & \\
\hline LCAP & 0.001 & -0.004 & 0.014 & 0.062 & -0.048 & 0.114 & 0.044 & 0.033 & 0.001 & -0.026 & 0.070 & 0.014 & 0.062 & & & & & & & & & & & & \\
\hline$A G$ & 0.073 & -0.055 & 0.124 & -0.040 & -0.110 & 0.057 & 0.119 & 0.118 & 0.079 & 0.113 & 0.094 & 0.030 & 0.059 & 0.174 & & & & & & & & & & & \\
\hline GMBH & 0.080 & -0.083 & 0.034 & -0.013 & -0.022 & -0.059 & -0.216 & -0.009 & 0.038 & -0.030 & 0.058 & 0.058 & 0.007 & -0.059 & -0.281 & & & & & & & & & & \\
\hline OTHER & 0.009 & 0.015 & -0.012 & -0.006 & 0.017 & 0.018 & -0.100 & -0.022 & 0.000 & 0.015 & 0.008 & 0.046 & 0.017 & -0.007 & -0.097 & -0.123 & & & & & & & & & \\
\hline LSIZE & 0.128 & 0.022 & 0.454 & 0.042 & -0.108 & -0.087 & 0.039 & 0.112 & 0.106 & 0.149 & 0.061 & 0.070 & 0.058 & 0.170 & 0.443 & 0.014 & -0.006 & & & & & & & & \\
\hline IND_1 & -0.030 & -0.030 & -0.008 & 0.035 & 0.086 & -0.002 & 0.039 & -0.122 & 0.106 & -0.002 & 0.047 & 0.047 & 0.029 & 0.003 & -0.034 & 0.008 & 0.001 & -0.019 & & & & & & & \\
\hline IND_2 & 0.055 & 0.011 & -0.015 & 0.029 & -0.041 & 0.067 & 0.096 & 0.290 & 0.048 & -0.064 & 0.081 & -0.041 & 0.082 & -0.060 & 0.124 & 0.028 & -0.035 & -0.065 & -0.274 & & & & & & \\
\hline IND_3 & -0.068 & 0.007 & 0.020 & -0.110 & -0.006 & -0.026 & -0.171 & -0.136 & -0.065 & 0.090 & -0.032 & 0.006 & -0.028 & 0.093 & -0.081 & -0.031 & 0.051 & 0.024 & -0.225 & -0.707 & & & & & \\
\hline CONST & -0.042 & -0.110 & -0.021 & -0.011 & 0.055 & -0.001 & 0.004 & -0.072 & 0.068 & 0.029 & 0.082 & 0.107 & 0.033 & 0.056 & -0.003 & 0.055 & -0.029 & 0.041 & 0.058 & -0.160 & 0.145 & & & & \\
\hline $\begin{array}{l}\text { CRED } \\
\text { COND } \\
\end{array}$ & -0.025 & -0.085 & 0.013 & 0.014 & 0.046 & -0.004 & -0.004 & -0.054 & 0.051 & 0.023 & 0.062 & 0.095 & 0.042 & 0.091 & 0.011 & 0.035 & -0.016 & 0.061 & 0.073 & -0.155 & 0.162 & 0.898 & & & \\
\hline $\begin{array}{l}\text { LINE } \\
\text { LINE }\end{array}$ & -0.024 & -0.095 & -0.009 & -0.008 & 0.057 & -0.002 & -0.001 & -0.079 & 0.035 & 0.031 & 0.089 & 0.107 & 0.031 & 0.049 & 0.015 & 0.029 & -0.040 & 0.044 & 0.071 & -0.127 & 0.117 & 0.913 & 0.812 & & \\
\hline $\begin{array}{l}\text { INFO- } \\
\text { VC }\end{array}$ & -0.062 & -0.107 & -0.059 & -0.036 & 0.042 & 0.002 & 0.015 & -0.057 & 0.093 & 0.020 & 0.064 & 0.080 & 0.014 & 0.007 & -0.034 & 0.081 & -0.019 & 0.001 & 0.007 & -0.138 & 0.102 & 0.811 & 0.544 & 0.582 & \\
\hline CONST & -0.010 & -0.089 & -0.023 & -0.042 & 0.037 & -0.001 & 0.037 & 0.033 & 0.064 & 0.038 & 0.070 & 0.026 & 0.043 & 0.024 & 0.051 & 0.033 & 0.002 & 0.040 & 0.057 & -0.068 & 0.058 & 0.530 & 0.477 & 0.455 & 0.459 \\
\hline
\end{tabular}


Table A.9c: Correlation matrix for cross-section 2006 (N=615)

\begin{tabular}{|c|c|c|c|c|c|c|c|c|c|c|c|c|c|c|c|c|c|c|c|c|c|c|c|c|}
\hline & BREAK & GROWTH & MAIN & UNEMPLOY & LAGE & GENDER & QUAL & $\mathrm{R} \& \mathrm{D}$ & $\mathrm{NP}$ & MP & PCOMP & NPCOMP & LCAP & $A G$ & GMBH & OTHER & LSIZE & IND_1 & IND_2 & IND_3 & $\begin{array}{l}\text { DEBT } \\
\text { CONSTT }\end{array}$ & $\begin{array}{l}\text { CRED } \\
\text { COND } \\
\end{array}$ & $\begin{array}{c}\text { CRED } \\
\text { LINE }^{-}\end{array}$ & $\begin{array}{c}\text { DEBT } \\
\text { INFO } \\
\end{array}$ \\
\hline GROWTH & 0.080 & 1.000 & & & & & & & & & & & & & & & & & & & & & & \\
\hline MAIN & -0.028 & -0.047 & & & & & & & & & & & & & & & & & & & & & & \\
\hline UNEMPLOY & -0.033 & -0.046 & 0.062 & & & & & & & & & & & & & & & & & & & & & \\
\hline LAGE & -0.064 & -0.073 & 0.040 & 0.078 & & & & & & & & & & & & & & & & & & & & \\
\hline GENDER & 0.072 & 0.021 & 0.066 & 0.060 & -0.032 & & & & & & & & & & & & & & & & & & & \\
\hline QUAL & 0.039 & 0.054 & -0.021 & -0.065 & 0.037 & 0.020 & & & & & & & & & & & & & & & & & & \\
\hline$R \& D$ & -0.061 & 0.033 & -0.025 & 0.035 & -0.124 & 0.008 & 0.091 & & & & & & & & & & & & & & & & & \\
\hline NPCOMP & -0.043 & 0.091 & -0.052 & -0.009 & 0.015 & 0.012 & 0.037 & 0.250 & & & & & & & & & & & & & & & & \\
\hline MP & -0.006 & 0.118 & -0.020 & 0.010 & 0.004 & 0.003 & 0.005 & 0.248 & 0.058 & & & & & & & & & & & & & & & \\
\hline PCOMP & -0.008 & 0.016 & 0.048 & 0.002 & -0.059 & -0.024 & 0.052 & -0.002 & -0.019 & -0.009 & & & & & & & & & & & & & & \\
\hline NPCOMP & 0.140 & -0.002 & 0.008 & -0.050 & -0.016 & -0.035 & 0.056 & 0.036 & 0.077 & 0.155 & 0.032 & & & & & & & & & & & & & \\
\hline LCAP & 0.009 & 0.004 & 0.087 & -0.019 & 0.134 & 0.028 & -0.017 & 0.043 & -0.008 & 0.041 & 0.053 & 0.043 & & & & & & & & & & & & \\
\hline$A G$ & 0.019 & 0.042 & -0.029 & -0.079 & 0.084 & 0.129 & 0.096 & 0.033 & 0.090 & 0.069 & 0.034 & 0.091 & 0.233 & & & & & & & & & & & \\
\hline GMBH & -0.090 & 0.001 & -0.042 & -0.074 & -0.083 & -0.228 & 0.001 & 0.078 & -0.013 & 0.029 & 0.018 & -0.042 & -0.068 & -0.270 & & & & & & & & & & \\
\hline OTHER & 0.004 & 0.043 & -0.077 & 0.059 & -0.006 & -0.071 & 0.031 & 0.072 & -0.027 & 0.080 & -0.003 & -0.048 & -0.025 & -0.064 & -0.137 & & & & & & & & & \\
\hline LSIZE & 0.051 & 0.421 & -0.006 & -0.099 & -0.112 & 0.038 & 0.149 & 0.145 & 0.102 & 0.136 & 0.087 & 0.080 & 0.186 & 0.374 & 0.003 & 0.020 & & & & & & & & \\
\hline IND_1 & 0.006 & 0.027 & 0.040 & 0.069 & -0.008 & 0.062 & -0.123 & 0.136 & 0.015 & 0.066 & 0.008 & -0.057 & 0.060 & -0.009 & -0.004 & -0.001 & 0.014 & & & & & & & \\
\hline IND_2 & 0.053 & -0.015 & 0.046 & -0.033 & 0.039 & 0.082 & 0.331 & 0.072 & -0.024 & 0.055 & 0.012 & 0.128 & -0.090 & 0.118 & 0.035 & -0.027 & -0.043 & -0.301 & & & & & & \\
\hline IND_3 & -0.056 & -0.022 & -0.126 & 0.005 & 0.032 & -0.182 & -0.190 & -0.091 & 0.071 & -0.082 & -0.047 & -0.060 & 0.083 & -0.076 & -0.032 & 0.070 & -0.018 & -0.204 & -0.694 & & & & & \\
\hline $\begin{array}{l}\text { DEBT- } \\
\text { CONST }\end{array}$ & -0.176 & -0.019 & 0.014 & 0.110 & -0.140 & -0.020 & -0.105 & 0.101 & 0.103 & 0.067 & -0.008 & 0.009 & -0.066 & -0.093 & 0.109 & 0.014 & 0.039 & 0.048 & -0.164 & 0.099 & & & & \\
\hline $\begin{array}{l}\text { CRED_- } \\
\text { CONDD } \\
\text { CRED }\end{array}$ & -0.176 & -0.020 & 0.047 & 0.100 & -0.103 & -0.027 & -0.132 & 0.073 & 0.074 & 0.069 & 0.049 & -0.016 & -0.026 & -0.066 & 0.072 & 0.009 & 0.042 & 0.073 & -0.194 & 0.113 & 0.920 & & & \\
\hline $\begin{array}{l}\text { LINE } \\
\text { DEBT }\end{array}$ & -0.149 & -0.031 & 0.009 & 0.092 & -0.122 & -0.021 & -0.111 & 0.091 & 0.089 & 0.041 & -0.017 & 0.039 & -0.061 & -0.069 & 0.089 & -0.004 & 0.031 & 0.065 & -0.134 & 0.085 & 0.922 & 0.831 & & \\
\hline $\begin{array}{l}\text { INFO } \\
\text { VC }\end{array}$ & -0.150 & -0.001 & -0.020 & 0.106 & -0.152 & -0.005 & -0.041 & 0.107 & 0.117 & 0.069 & -0.053 & 0.001 & -0.091 & -0.117 & 0.134 & 0.034 & 0.031 & -0.009 & -0.113 & 0.069 & 0.855 & 0.652 & 0.655 & \\
\hline CONST & -0.087 & 0.008 & -0.047 & 0.019 & -0.071 & -0.047 & -0.061 & 0.090 & 0.148 & 0.068 & 0.036 & 0.026 & -0.022 & -0.027 & 0.075 & 0.010 & 0.040 & -0.017 & -0.087 & 0.080 & 0.561 & 0.513 & 0.487 & 0.513 \\
\hline
\end{tabular}

